\section{Invited Speaker}

IS001

Sexual problems after laryngectomy

Singer S., Keszte J., Danker H., Wollbrück D., Meyer A., Schwarz $R$.

Universität Leipzig, Sozialmedizin, Leipzig

Objectives: To identify sexual problems after laryngectomy.

Patients and Methods: Multicenter study. A total of $n=218$ laryngectomy patients was interviewed face-to-face. Instruments: Dyadic Adjustment Scale (DAS), EORTC QLQ-H\&N35 and a structured interview.

Results: Sexuality is an important topic for the patients, even when they do not have a permanent partner. $23 \%$ state, that their sexual relationship is impaired due to the tracheostoma. 57\% do not enjoy sexuality as much as before the operation. $76 \%$ of the patients want to talk about sexual problems with their partner, $28 \%$ with a friend, $16 \%$ with a doctor, $6 \%$ with a speech therapist, and $10 \%$ with a person from the self help group.

Conclusions: Sexuality seems to be an important issue for laryngectomized patients. It is often affected and people are willing to talk about it.

\section{IS002}

\section{Die Bedeutung von Biomarkern für das Monitoring des Therapieansprechens aus präklinischer Sicht}

\section{Fichtner I. ${ }^{1}$, Merk J. ${ }^{2}$, Soong R. ${ }^{3}$, Becker M. ${ }^{4}$, Rolff J. ${ }^{4}$}

${ }^{1}$ Max-Delbrück-Centrum, Experimentelle Pharmakologie, Berlin; ${ }^{2}$ Evangelische Lungenklinik Berlin, Berlin; ${ }^{3}$ National University of Singapore, Singapore; ${ }^{4}$ Experimentelle Pharmakologie \& Onkologie $\mathrm{GmbH}$, Berlin

Among the potential predictive biomarkers for novel targeted therapies the epidermal growth factor receptor (EGFR) plays an important role. It is expressed in almost all tissues and is overexpressed in many cancer types among them lung cancer. With the newly developed tyrosine kinase inhibitors (TKI) Gefitinib and Erlotinib as well as the monoclonal antibody Cetuximab new drugs are available for the targeted treatment of patients with lung cancer. The evaluation of clinical trials using Erlotinib and Gefitinib revealed no correlation between the EGFR expression and the response to therapy. It was demonstrated that only a small group (women, never-smokers and people with asian origin) did benefit from the treatment with TKIs. In addition, patients with mutations in the exon 19 or 21 of the EGFR gene showed a better response to a therapy with TKIs.

We have developed a series of novel lung cancer xenograft models. Fresh tumor material of patients with non small cell lung cancer (NSCLC) was subcutaneously transplanted to immunodeficient mice shortly after removal. Up to now more than 100 samples have been transplanted from which 25 passagable models could be generated. 54\% of the established xenograft lines were derived from squamous cell carcinomas and $22 \%$ from adenocarcinomas. They mainly belonged to T2 or T3 stages of TNM classification and all except one originated from long-term smokers. It was demonstrated that the early murine passages (up to 10) correlated with the original tumor regarding histology, the expression of the surface proteins E-cadherin, EpCAM, the cell proliferation marker Ki-67 and in gene profiling (Affymetrix). 8/25xenografts were sensitive towards Cetuximab and 4/25 towards Erlotinib showing more than 50\% tumor growth inhibition. The analysis of the EGFR gene revealed $5 / 23$ tumors with mutations but these were not related to a better response to TKIs Erlotinib or Cetuximab. 5/25 models with K-ras mutations were found among the xenografts and in 12/25 different models mutations in the p53 gene could be located. But none of these mutations alone or in combination was correlated with a specific response towards anti-EGFR therapies. Western analysis was performed for the expression of different pathway related proteins (EGFR, ERK 1/2, Stat1, and phosphorylated forms). While none of the constitutive expression levels was related to therapeutic response, the EGFR protein was down-regulated after TKI treatment only in some of the sensitive xenografts but not in the resistant ones identifying the ability for dynamic regulation as potential prediction marker.

In summary, we have available a panel of well characterized NSCLC xenografts closely correlating with the clinical situation and being able to identify biomarkers and their regulation after therapeutic interventions both at genetic and at protein level.

\section{IS003}

\section{Assessment of quality of life in cancer patients and its consequences for oncological care}

Holzner B., Giesinger J.

Med. Universität Innsbruck, Univ.-Klinik für Psychiatrie, Innsbruck

Background: Quality of Life (QOL) measurement as a clinical instrument has the potential of playing an important role in clinical decision making, e.g. improvement of symptom control by screening special, problems, enhancing patient participation in the treatment process etc.. Prerequisite for this is that QOL assessments are integrated in the daily clinical routine. The use of computer-technology is indispensable for such an implementation.

Aims: Studies in which computer-aided routinely assessment of QOL in the clinical oncological practice was evaluated suggest some important benefits for the physicians, the patients and their treatment.

Aim of this project was the development of a tool for the computerized collection, processing and presentation of longitudinal QoL data.

Methods: The software developed is called "Computer based Health Evaluation System (CHES)". With the help of CHES, questionnaire subscales of various QOL instruments such as the EORTC QLQ-C30 or FACIT can be automatically calculated and presented as a graphical bar chart. Reference values (e.g. mean, 25th and 75th percentile) are incorporated in the graphical format for enhancing the significance of the QoL data.

The longitudinal graphical presentation enables the physicians to detect QOL deficits (e.g. emotional problems) and problems in domains such as fatigue and pain at one single glance. Furthermore it is possible to identify the impact of initiated medical interventions on certain QOL domains as well as on the course of symptoms.

Results: The software was successfully tested in a longitudinal study investigating the impact of computerized EORTC QLQ-C30 assessment in the daily clinical routine of an oncological outpatient unit for the treatment of chemotherapy patients $(\mathrm{n}=145)$.

Patients' satisfaction with care and QOL (emotional, social domain and overall health) improved in the group using CHES (for real-time QOL feedback) in the course of CT-treatment. This was especially true for the subgroup of CT nonresponders. In one sixth of the patient visits medical interventions were initiated as a consequence of the interpretation and discussion of the QOL profile. Conclusion: The computerized collection of QOL data (with CHES) is well accepted by the patients and physicians. It allows "online monitoring“ of the course of QOL and patient reported symptoms and hence facilitates individualized treatment. Therefore the use of QOL assessments has the power of changing clinical practice. Furthermore it has to be considered that routine assessment of QoL ensures accompanied collection of data which may subsequently be used for the evaluation of clinical treatment strategies such as comparison of different chemotherapeutic regimens. Based on the promising results CHES has been developed further and is now used in various clinical oncological settings.

\section{KARGER}

Fax +497614520714

E-Mail Information@karger.de

www.karger.com
(C) 2008 S. Karger GmbH, Freiburg 


\section{IS004}

\section{Prostate cancer - Epidemiological and clinical results in Germany}

\section{Schubert-Fritschle G. ${ }^{1}$, Engel J. ${ }^{2}$, Eckel R. ${ }^{1}$, Hölzel D. ${ }^{1}$ \\ ${ }^{1} \mathrm{IBE}$, Tumorregister München, München; ${ }^{2} \mathrm{LMU}$ München, Tumorregister München / IBE, München}

Background: For prostate cancer increasing incidence rates go along with stable mortality rates. Improved possibilities of early detection especially by PSA-test result in an age and stage shift for the affected population.

Methods: Cancer registries in Germany collect data about cancer patients to evaluate changes in epidemiological measures, and for analysis of clinical aspects like stage, histology or grading and characteristics of cancer care and its outcome. More than 40 German cancer centres were contacted. A pooled data set with prostate cancer patients diagnosed in the years 1998-2005 will be analysed to describe the situation for this most frequent cancer in male population. Stage shift, influence of prognostic factors like Gleason score, changes in therapeutic procedures, and survival will be main aspects of analysis.

Results: Prostate cancer ranks at first position in incidence, at third in mortality statistics for men in Germany. GEKID and RKI (1) estimate more than 48.000 new cases per year, corresponding to a raw incidence of about $120 / 100.000$. Observed incidences are in part considerably higher (2). An age shift of 1-2 years towards younger patients is the result of earlier diagnoses. Therapeutic approach tends to nerve preserving surgery.

The analysis will focus on the prognostic value of preoperative PSA, Gleason score, stage of disease and type of treatment with respect to age, and its influence on disease free, overall, and relative survival. The description of treatment will pose a challenge. Time trends of prognostic factors and its effects on outcome will also be estimated.

Conclusion: German cancer registries are meanwhile an excellent source for clinical and epidemiological data. This activity aims to demonstrate importance of this kind of data and its necessary quality improvements and the demand for stage and treatment information.

References:

1. Gesellschaft der epidemiologischen Krebsregister in Deutschland e.V. (GEKID) mit dem Robert Koch Institut (RKI) (Hrsg.): Krebs in Deutschland-Häufigkeiten und Trends, 5.überarbeitete, akt. Ausgabe, Saarbrücken 2006

2. Tumorregister München http://www.tumorregister-muenchen.de/facts/base/ base_C61_G.pdf

\section{IS005}

Dialectical Group Intervention (DGI) for relatives of palliative cancer patients: A randomized-controlled prevention study

\author{
Fegg M. ${ }^{1}$, Hauke G. ${ }^{2}$, Brandstätter M. ${ }^{1}$, Kögler M. ${ }^{1}$, Hentrich M. ${ }^{3}$, \\ Rechenberg-Winter P. ${ }^{1}$, Borasio G.D. ${ }^{1}$ \\ ${ }^{1}$ Ludwig-Maximilians-Universität, Interdisziplinäres Zentrum für \\ Palliativmedizin, München; ${ }^{2}$ Centrum für Integrative Psychotherapie, \\ München; ${ }^{3}$ Städtisches Klinikum Harlaching, München
}

Background: While support programs for tumour patients have been developed and evaluated, programs for relatives of palliative cancer patients are lacking. Therefore, a dialectical group intervention (DGI) was developed, consisting of seven sessions, based on new developments in behavioural therapy. In the so called third wave therapies strategies promoting acceptance are used in addition to change-oriented methods. Mindfulness as a method of attention guidance is supplemented by a resource-oriented approach according to Schwartz's value model: especially in critical situations, values offer important orientation - they have a positive connotation, are stable over time, and reflect what is valued, important and wished for by the individual.

Research questions: Is DGI a feasible and effective support program for relatives of palliative cancer patients, regarding the outcomes of psychological well-being, meaning-in-life, burden, and life satisfaction? Is DGI better than standard care with regard to the quality of the support of relatives of palliative cancer patients (comparison with control group).

Methods: The feasibility and effectiveness of the DGI is evaluated in a randomized controlled trial at the Interdisciplinary Center for Palliative Medicine,
Ludwig-Maximilians-University, and the palliative care unit of the Municipal Hospital Munich-Harlaching. Participants are asked to complete self-rating questionnaires in four assessments (baseline, pre-treatment, post-treatment, and 3-months-follow-up). The control group receives documented standard care.

\section{IS006}

\section{Knochengesundheit in der Onkologie: Kieferosteonekrose}

\section{Grötz K.A.}

HSK Dr. Horst-Schmidt-Kliniken, Klinik für Mund-Kiefer-Gesichtschirurgie, Wiesbaden

Der Kieferknochen stellt bei der Betrachtung onkologischer Therapiefolgen eine Besonderheit dar, weil er einerseits über Weichteilknochenwunden der Mundhöhle leicht und epidemiologisch häufig involviert werden kann, andererseits Kompromittierungen erhebliche Auswirkungen auf Kau-, Schluck- und Sprechfunktion sowie Physiognomie haben. Die beiden wichtigsten Vertreter einer Kiefernekrose onkologischer Patienten sind die infizierte Osteoradionekrose (IORN) und die Bisphosphonat-assoziierte Kiefernekrose (BP-ONJ). Während die IORN seit ca. 100 Jahren bekannt und die Pathogenese weitgehend geklärt ist, stellt sich die 2003 erstbeschriebene BPONJ ätiologisch noch unklar dar. Gemeinsam ist wiederum beiden, dass die manifeste IORN, wie auch BP-ONJ schwierig zu therapieren ist und meist mit umfangreichen Kieferdefekten einhergehen. Deshalb nimmt für beide Entitäten die Prophylaxe eine herausragende Rolle ein. Wichtige lokale Auslöser beider Nekrosen sind Knochenwunden (Zahnextraktionen, Kieferoperationen), dentogene Infektionen und Prothesendruckstellen. Deshalb ist für die IORN und die BP-ONJ eine adjuvante und peritherapeutische, zahnärztliche (ggf. auch kieferchirurgische) Betreuung nachhaltig zu empfehlen, die zwischenzeitlich in wissenschaftlichen Stellungnahmen (www.dgzmk.de) und Leitlinien (www.awmf.de und www.kieferchirurgie.de) konsentiert hinterlegt ist. In dieser Betreuung spielt prätherapeutisch die Sanierung von Entzündungsherden, inklusive der Entfernung nicht erhaltungswürdiger Zähne eine entscheidende Rolle. Während und nach der onkologischen Therapie werden einerseits durch regelmäßiges Recall neue Auslöser rechtzeitig identifiziert und eliminiert und andererseits wird die kaufunktionelle und orofaciale Rehabilitation als Teil der psychosozialen Reintegration verfolgt. Dies hat große Bedeutung für die Gestaltung der Lebensqualität des onkologischen Patienten.

\section{IS007}

\section{Bisphosphonat-assoziierte Kiefernekrose (BP-ONJ) - Prophylaxe, Therapie, Leitlinien}

\section{Grötz K.A.}

HSK Dr. Horst Schmidt-Kliniken, Klinik für Mund-Kiefer-Gesichtschirurgie, Wiesbaden

Die BP-ONJ wurde erstmals 2003 beschrieben und danach durch eine Vielzahl von Kasuistiken und Fallsammlungen in der internationalen Literatur präsent. Die Inzidenz der BP-ONJ liegt bei onkologischen Patientenkollektiven (Plasmocytom, Mamma-Ca., Prostata-Ca.) zwischen 3 und $10 \%$, aktuelle prospektive Studien verweisen sogar auf Werte über $10 \%$. OsteoporosePatienten sind dagegen mit einer deutlich niedrigeren Inzidenz belastet. Die manifeste BP-ONJ ist schwierig zu therapieren und geht meist mit umfangreichen Kieferdefekten einher. Wichtige lokale Auslöser sind Knochenwunden (Zahnextraktionen, Kieferoperationen), dentogene Infektionen und Prothesendruckstellen. Deshalb nimmt die Vermeidung einer BP-ONJ eine herausragende Rolle ein. Darin spielt prätherapeutisch die Sanierung von Entzündungsherden, inklusive der Entfernung nicht erhaltungswürdiger Zähne eine entscheidende Rolle. Während und nach der BP-Therapie werden durch regelmäßiges Recall neue Auslöser rechtzeitig identifiziert und eliminiert. Das konsentierte Betreuungskonzept beeinhaltet somit sowohl die Prophylaxe, Prävention und Früherkennung von zahnärztlicher Seite (wissenschaftliche Stellungnahme; www.dgzmk.de), als auch die Diagnostik, Therapie und Rehabilitation einer manifesten BP-ONJ von Seiten der Mund-KieferGesichtschirurgie (Leitlinie der DGMKG; www.awmf.de). Eine herausragende Bedeutung hat dabei die Eruierung des individuellen Risikoprofils, das 
neben der Grunderkrankung viele weitere systemische und lokale Faktoren zu berücksichtigen hat. Um die hierfür notwendige, interdisziplinäre Kommunikation zwischen BP-Verordnenden einerseits und betreuenden Zahnärzten und Kieferchirurgen andererseits zu erleichtern, wurde auf Intitiative der ASO ein Konsil-Zettel im Konsens erarbeitet, der unter der homepage (www.onkosupport.de) herunterladbar ist.

\section{IS008}

\section{Spätfolgen onkologischer Therapieverfahren am Knochen}

Grötz K.A

HSK Dr. Horst Schmidt Kliniken, Klinik für Mund-Kiefer-Gesichtschirurgie, Wiesbaden

Der Kieferknochen stellt bei der Betrachtung onkologischer Therapiefolgen eine Besonderheit dar, weil er einerseits über Weichteilknochenwunden der Mundhöhle leicht und epidemiologisch häufig involviert werden kann, andererseits Kompromittierungen erhebliche Auswirkungen auf Kau-, Schluck- und Sprechfunktion sowie Physiognomie haben. Die beiden wichtigsten Vertreter einer manifesten Kiefernekrose sind die infizierte Osteoradionekrose (IORN) und die Bisphosphonat-assoziierte Kiefernekrose (BP-ONJ). Während die IORN seit ca. 100 Jahren bekannt und die Pathogenese weitgehend geklärt ist, stellt sich die 2003 erstbeschriebene BP-ONJ ätiologisch noch unklar dar. Gemeinsam ist wiederum beiden, dass die manifeste IORN, wie auch BP-ONJ schwierig zu therapieren ist und meist mit umfangreichen Kieferdefekten einhergehen. Deshalb nimmt für beide Entitäten die Prophylaxe eine herausragende Rolle ein. Wichtige lokale Auslöser beider Nekrosen sind Knochenwunden (Zahnextraktionen, Kieferoperationen), dentogene Infektionen und Prothesendruckstellen. Deshalb ist für die IORN und die BP-ONJ eine adjuvante und peritherapeutische, zahnärztliche (ggf. auch kieferchirurgische) Betreuung nachhaltig zu empfehlen, die zwischenzeitlich in wissenschaftlichen Stellungnahmen (www.dgzmk.de) und Leitlinien (www.awmf.de und www.kieferchirurgie.de) konsentiert hinterlegt ist. In dieser Betreuung spielt prätherapeutisch die Sanierung von Entzündungsherden, inklusive der Entfernung nicht erhaltungswürdiger Zähne eine entscheidende Rolle. Während und nach der onkologischen Therapie werden einerseits durch regelmäßiges Recall neue Auslöser rechtzeitig identifiziert und eliminiert und andererseits wird die kaufunktionelle und orofaciale Rehabilitation als Teil der psychosozialen Reintegration verfolgt. Dies hat große Bedeutung für die Gestaltung der Lebensqualität des onkologischen Patienten.

\section{IS009}

\section{Alternative medicine versus evidence based complementary oncology - Two different systems of medicine?}

\section{Huebner $\mathrm{J}$.}

Habichtswald-Klinik, Onkologie, Kassel

The wish of cancer patients to find a "natural" treatment is due to the strong impact of the diagnosis on the patient, his emotional as well as his somatic well-being.

An abundance of so called "alternative" ways is presented in print media and internet, promising cure by strengthening patient's powers and protection from harm of chemo- and radiotherapy.

Typically we find no publications in serious journals and no studies following GCP criteria

Discussing this lack of evidence with protagonists of alternative medicine is futile because they deny the rules of EBM as not applicable to this special kind of therapy. Even people more aware of the realistic limitations of natural treatments often make this point reclaiming different rules for evaluation of cognition based medicine.

On the other side we have growing data which support the influence of natural substances on tumour cells. Preliminary data show that phytotherapy can be able to alleviate symptoms or even to slow down growth of tumour cells by targeting the same targets as modern targeted substances. We do not know whether they enhance or disturb our therapy and whether serum levels reached by tablets available are sufficient. We have only rudimentary information on their influence on pharmacokinetics of conventional substances.
We have to face that patients are using these substances now and that this can lead to interactions and influences of therapy outcome. We will have to take this into consideration whenever counselling a single patient or planning a new study.

There is no reasonable argument to suppose that there exists any therapy which has not to prove its usefulness and that it is better than the standard therapy so far.

One has to concede that there are some principal problems with studies of natural compounds starting with the fact that often it is not easy to clearly define them biochemically. On the other hand we are dealing with diseases and treatment outcomes, which can be evaluated by just the same parameters and methods as conventional medicine.

There is no reasonable argument that natural compounds cannot be studied the same way as synthetic ones: we have in vitro and in vivo data. Studies from phase I to III can be designed.

The question in the title has to be answered clearly: alternative and complementary medicine are fundamentally different systems of thinking.

The question whether there is a fundamental difference between conventional and complementary medicine seems more controversial and interesting because it is pointing at a possible common future.

The talk will give some examples of intracellular targets of phytotherapies and of interactions. It will sum up some possible ways to integrate complementary oncology in clinical research and studies.

\section{IS010}

\section{Die Mammastammzelle: Biologische Bedeutung und mögliche klinische Konsequenzen}

Rody $A$

Universitätsklinikum, Frauenklinik, Frankfurt/M.

Aufgrund der ausgeprägten anatomisch-funktionellen Veränderungen der weiblichen Brustdrüse während Schwangerschaft und Stillphase, muß das Vorhandensein unreifer pluripotenter Progenitorzellen bzw. einer „Mammastammzelle“ postuliert werden.

Allerdings ist im humanen System eine allgemein akzeptierte Charakterisierung dieser Stammzelle bisher noch nicht gelungen. Es wird vermutet, dass die Mammastammzelle/-progenitorzelle als eine CK5/14+ Zelle charakterisiert werden kann. Aus diesen unreifen Vorstufen entwickelt sich dann eine glandulär/ luminale $(\mathrm{CK} 5 / 14+, \mathrm{CK} 8 / 18+)$ bzw. eine myoepitheliale Präkursorzelle (CK5/14+, p63, smActin), aus denen dann die reifen ductalen bzw. lobulären Zellen, sowie die Myoepithelzellen (p63, smActin) ausdifferenzieren. Unklar ist allerdings, in welchem Entwicklungsstadium eine gesunde Brustepithelzelle ihre hormonelle Ansprechbarkeit erhält.

In zahlreichen Untersuchungen konnte beobachtet werden, dass innerhalb eines heterogenen Tumors Zellen nachweisbar sind, die stammzellähnliche Eigenschaften haben und von deren proliferativer Aktivität ausgehend der Tumor sein Größenwachstum erfährt (,,Tumorstammzelle“). Andererseits können durch globale molekulare Untersuchungen (Genexpressionsanalysen) Karzinome identifiziert werden, die phänotypische Eigenschaften aufweisen, die dem eines unreifen (basalen) Zelltypes entsprechen (,Stammzelltumor“/ maturation arrest theory). Die Genexpressionsanalyse erlaubt es, die Expression zahlreicher ,putativer" Stammzellmarker parallel zu untersuchen, und somit eine Klassifikation von Mammakarzinomen auf der Grundlage eines biologischen Modells vorzunehmen. Mit Hilfe dieser globalen molekularen Analyse können verschiedene pathophysiologische und auch klinisch relevante Aspekte neu beleuchtet werden.

\section{IS011}

\section{Genchipdiagnostik in der Senologie - Quo vadis?}

Rody $A$.

Universitätsklinikum, Frauenklinik, Frankfurt/M

Die Untersuchung des gesamten menschlichen Genoms mit Hilfe der Genexpressionsanalyse an einer Tumorprobe hat viele Erwartungen geweckt, die bis dato nicht oder nur unzureichend erfüllt werden konnten. In der wissenschaftlichen Literatur wurden zahlreiche prognostische und prädiktive Signaturen für das Mammakarzinom identifiziert, die zum einen nur wenige 
überlappende Schlüsselgene aufweisen („,master genes“), zum anderen eine unzureichende Reproduzierbarkeit zeigen. Die klinische Relevanz in entsprechenden prospektiven Phase III-Studien steht nach wie vor aus. Neben methodischen Problemen (biostatistische Analyse, Ergebnisreproduzierbarkeit, Patientenkollektiv, Plattform), spielt die Heterogenität des Mammakarzinoms eine ganz entscheidende Rolle. Östrogen- und Proliferationsabhängigkeit sind wesentlichen biologischen Faktoren, die in der Mehrzahl der identifzierten Signaturen die entscheidenden Grundprinzipien darstellen. Ein wichtiger Schritt zu einer erfolgreichen Anwendung solcher globalen Analysetechniken scheint die klinisch und molekularbiologisch sinnvolle Klassifikation des Untersuchungskollektivs zu sein. Hierüber könnte eine verbesserte funktionelle und biologisch plausiblere Untersuchung der Tumore möglich sein. Des weiteren spielen biologische Modelle, wie z.B. das Mammastammzellkonzept eine zunehmende Rolle für das Verständnis und die Pathophysiologie von Brustkrebs.

Zusammenfassend muß die Genexpressionsanalyse noch den Beweis der klinischen Relevanz führen und die Analysestrategie auf sinnvolle Fragestellungen im Sinne der Untersuchung klar definierter Subgruppen fokussieren.

\section{IS012 \\ Capecitabine given concomitantly or in sequence with $E C \rightarrow$ Docetaxel as neoadjuvant treatment for early breast cancer: GeparQuattro - a GBG/AGO intergroup-study}

\author{
von Minckwitz G. ${ }^{1,2}$, Rezai M. ${ }^{3}$, Loibl S. ${ }^{2}$, Fasching $P .{ }^{4}$,

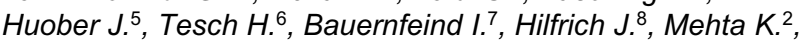 \\ Untch $M .^{9}$ \\ ${ }^{1}$ Universitätsklinikum, Frauenklinik, Frankfurt a.M.; ${ }^{2} \mathrm{GBG}$ Forschungs \\ $\mathrm{GmbH}$, Neu-Isenburg; ${ }^{3}$ Senologie Düsseldorf, Düsseldorf; \\ ${ }^{4}$ Universitätsklinikum, Frauenklinik, Erlangen; ${ }^{5}$ Senologiezentrum \\ Ostschweiz, St. Gallen; ${ }^{6}$ Onkologie Bethanien, Frankfurt a.M.; \\ ${ }^{7}$ Frauenklinik München, München; ${ }^{8}$ Henriettenstiftung, Frauenklinik, \\ Hannover; ${ }^{9}$ Helios Kliniken Berlin Buch, Frauenklinik, Berlin
}

Background: Integration of new cytotoxic agents is possible by either simultaneous or sequential addition to established regimens. Direct comparison of these strategies is biased by differences in treatment duration. A three-arm neoadjuvant study (GeparQuattro) was designed to address this question by adding capecitabine (X) to docetaxel (D) after pretreatment with epirubicin/cyclophosphamide (EC).

Patients and methods: Patients (pts) were eligible in whom adjuvant chemotherapy would be considered otherwise. Therefore, either large operable (T3) and locally advanced (T4), or estrogen (ER) and progesterone (PR) negative receptor status, or ER/PR positive tumors but clinically node-positive disease were recruited to receive 4 cycles of $\mathrm{EC}\left(90 \mathrm{mg} / \mathrm{m}^{2} / 600 \mathrm{mg} / \mathrm{m}^{2}\right)$ and to be than randomized to either 4 cycles of D $\left(100 \mathrm{mg} / \mathrm{m}^{2}\right)$ or 4 cycles of DX $\left(75 \mathrm{mg} / \mathrm{m}^{2} / 1800 \mathrm{mg} / \mathrm{m}^{2}\right)$ or 4 cycles of $\mathrm{D}\left(75 \mathrm{mg} / \mathrm{m}^{2}\right)$ followed by 4 cycles of $\mathrm{X}\left(1800 \mathrm{mg} / \mathrm{m}^{2}\right)(\mathrm{D} \rightarrow \mathrm{X})$. Pts with HER-2 positive tumors received trastuzumab concomitantly with all regimens. The primary endpoint was pathologic complete response (pCR) at surgery. The co-primary objectives were to assess the effect of $\mathrm{X}$ by comparing $\mathrm{EC} \rightarrow \mathrm{D}$ vs. $\mathrm{EC} \rightarrow \mathrm{DX}+\mathrm{EC} \rightarrow$ $\mathrm{D} \rightarrow \mathrm{X}$ (effect of $\mathrm{X}$ ) and to assess the effect of time (24 vs 36 weeks) by comparing $\mathrm{EC} \rightarrow \mathrm{D}+\mathrm{EC} \rightarrow \mathrm{DX}$ vs $\mathrm{EC} \rightarrow \mathrm{Doc} \rightarrow \mathrm{X}$. The trial was designed to detect an increase in $\mathrm{pCR}$ from $17 \%$ to $23.5 \%$ (OR 1.5) for each comparison. Results: Between 08/05 and 12/06 1510 pts were recruited in 115 centers and after receiving 4 cycles EC, 1421 pts were randomized to $\mathrm{D}(\mathrm{N}=471)$, DX $(\mathrm{N}=471)$, and $\mathrm{D} \rightarrow \mathrm{X}(\mathrm{N}=479)$. $\mathrm{pCR}$ was observed in around $21 \%$ in all three treatment groups. No statistically significant difference neither for the effect of capecitabine or for the effect of treatment duration was found. Breast conserving surgery was possible in $65 \%$ of these patients. Hematological toxicity was similar among the three arms. Only leucopenia was more frequent in the docetaxel monotherapy arm. Febrile neutropenia was observed in around $7 \%$ of patients. The simultaneous administration of docetaxel and capecitabine was associated with significantly more non haematological toxicities (i.e. diarrhea, nail changes, hand-foot-syndrome).

Conclusions: Addition of $\mathrm{X}$ to EC-T does not allow administration of $\mathrm{T}$ and $\mathrm{X}$ at full dose, leads to more non-hematologic toxicities and does not improve pathologic response in general. Prolongation of neoadjuvant chemotherapy reduces patient's compliance and does not improve pathologic response.
IS013

Death as an everyday challange - Risc or chance for a team

\section{Gaspar M.}

Hamm-Kliniken, Psychosozial, St. Peter-Ording

How is death experienced in a medical work environment where dying people are the norm? There are many indications of the negative consequences of working with severely ill or terminally ill people. However, an increasing number of people deliberately choose to help dying people. This suggests that despite the strain, these work environments also offer positive aspects. This presentation will focus on which factors determine whether the immense confrontation with death leads to a chance or a risk for teams.

\section{IS014}

\section{Radiotherapy in SCLC limited disease}

Klautke G., Fietkau R.

Universität Rostock, Strahlentherapie, Rostock

SCLC was always classified as a systemic disease, even when locally limited. Chemotherapy alone was the standard treatment for limited-stage SCLC; accordingly, local recurrence rates were as high as $90 \%$. Two meta-analyses showed that thoracic irradiation improves local control (LC) and survival (OS). So radiotherapy has been an integral part of treatment of SCLC LD, normally administered sequentially, after completion of chemotherapy.

The effect of the timing of radiotherapy on LC and OS has been investigated in a number of randomized clinical trials. Trials with thoracic radiation starting with the first or second course of a platinum containing platinum chemotherapy, improve LC and OS. In Jeremic's early chemoradiotherapy group, LC was $58 \%$ vs. $37 \%$ ( $p<0.05)$, OS was 34 months vs. 26 months $(\mathrm{p}=0.027)$, and the distant metastasis rate was $51 \%$ vs. $55 \%$. Six meta-analyses demonstrate also, that early radiotherapy improves LC and OS without further intensivation of the whole treatment schedule.

Based on the study of Turrisi, hyperfractionated accelerated radiation (HART) (2x $1,5 \mathrm{~Gy}$ to $45 \mathrm{~Gy}$ ) seems to be the standard fractionation. However, the $45 \mathrm{~Gy}$ dose used in the conventional fractionation (CFRT) must be criticized as too low. In a retrospective analysis of Tada, LC with CFRT to a total dose of 45Gy within 4 years was only $56 \%$ compared to $70 \%$ in patients receiving a total dose of $50 \mathrm{~Gy}$. Choi demonstrated that $45 \mathrm{~Gy}$ is the maximum tolerable dose for concurrent chemoradiotherapy when radiation is administered in $1.5 \mathrm{~Gy}$ twice daily. Acute esophagitis is the dose-limiting toxicity (DLT). No DLT occurred in the CFRT, even with a total dose of $70 \mathrm{~Gy}$. The available data justifies the use of concurrent chemoradiotherapy using either HART to a total dose of $45 \mathrm{~Gy}$ or CFRT to a total dose of at least $56 \mathrm{~Gy}$ for treatment SCLC LD. 40 to $50 \%$ of all patients with SCLC develop brain metastases. A meta-analysis investigated prophylactic cranial irradiation (PCI) in SCLC LD patients who achieved a complete response to therapy. PCI resulted in statistically significant improvement of disease-free survival and OS. Moreover, the reduction of the occurrence of brain metastases was dose-dependent. The positive effect of PCI in SCLC ED patients has now been proven in a new EORTC study. So it is a new question, wether patients with SCLC LD with partial response need a PCI, too? (references see Klautke et al, 2008).

\section{IS015}

\section{Diagnostische Verfahren in der Naturheilkunde: Was ist} von ihnen zu halten?

\section{Münstedt K., El-Safadi S.}

Universität Gießen, Frauenklinik, Gießen

Neben alternativen und komplementären Therapien existieren zahlreiche komplementäre und alternative diagnostische Verfahren. Da gibt es labordiagnostische Methoden (z. B. Spektralanalyse des Vollblutes nach Rilling, Carcinochrom-Reaktion (CCR) nach Gutschmid von Blut und Urin), Serumtests (z. B. Groß'sche Reaktion mit Quecksilberchlorid, Serum-in-aqua-Test), magische Methoden (z. B. Pendeldiagnose, Wünschelrutendiagnose), Bioelektrische Methoden (z. B. Biotonometrie nach Rilling, Kirlian-Photographie), 
Diagnoseverfahren aus morphologischen Strukturen (z. B. Fussreflexzonendiagnostik, Vorfelddiagnostik nach Mayr).

Die meisten Methoden wurden bisher nicht geprüft. In jüngerer Zeit wurden die Irismikroskopie und die Dunkelfeldmikroskopie, zwei weitverbreitete Verfahren auf den Prüfstand gestellt und ihre diagnostische Wertigkeit auf die Diagnose „Krebs“ gestellt. In Übereinstimmung mit früheren Untersuchungen ergaben die Studien, dass beide Verfahren keinen Stellenwert haben.

Komplementäre diagnostische Verfahren sollte mehr Aufmerksamkeit geschenkt werden, denn diese können neben finanziellem Schaden auch negative Folgen haben, z. B. Verunsicherung bei falsch-positiver Diagnose als auch das Verleugnen von Krankheitssymptomen bei falsch-negativer Diagnose.

\section{IS016 \\ Herausforderungen der Komplementärmedizin und sinnvolle Reaktionen}

\author{
Münstedt K., Harren H. \\ Universität Gießen, Frauenklinik, Gießen
}

Übereinstimmend zeigen verschiedene Studien, dass abhängig von Tumorentität und Schwere der Erkrankung etwa die Hälfte aller Krebspatienten alternative oder komplementäre, d.h. ergänzende Methoden (CAM) anwendet. Im Gegensatz zu anderen Ländern sind in Deutschland Ärzte die Hauptprotagonisten der Anwendung, obwohl diese während des Studium und der Zeit danach kaum die Möglichkeit hatten, sich auf diesem Gebiet umfangreich und objektiv zu bilden, bzw. fortzubilden.

Entsprechend werden die Methoden kaum nach rationalen Gesichtspunkten ausgewählt. Wünsche, die von Seiten der Patienten an sie herangetragen werden und die durch Konzepte wie der von Nagel propagierten Patientenkompetenz geprägt sind, beeinflussen die Wahl von Methoden mehr als die Studien zu den verschiedenen Methoden.

Es stellt sich die Frage, wie von Seite einer offenen, aber evidenzbasierten Medizin, die sowohl das seelische als auch das körperliche Wohl der Patienten im Auge haben sollte, auf diese Herausforderung reagiert werden muss.

Da CAM-Methoden auch in anderen Bereichen, z.B. in der Geburtshilfe eine sehr große Rolle spielen, erscheinen folgende Maßnahmen sinnvoll, bzw. diskussionswürdig:

Integration von CAM in die Lehre, denn CAM kann nicht ignoriert werden

Angebote von unabhängigen Fortbildungen zu CAM, denn Protagonisten von CAM veranstalten zahlreiche Fortbildungen ohne Bezug zur Evidenz

Formulierung von sinnvollen CAM-Konzepten in den verschiedenen Therapiesituationen

Organisation einer Weiterbildung zum Thema CAM analog zum österreichischen Vorbild

Formulierung von S2-Leitlinien zur komplementären Therapie

IS017

\section{Distress screening with the questionnaire on stress in cancer patients}

\section{Herschbach $P$}

Technische Universität, München

Three versions of the Questionnaire on Stress in Cancer Patients (QSC) will be presented.

The QSC-R23 is a disease-specific questionnaire to assess psychosocial stress in cancer patients (all diagnoses and treatment settings). It can be applied to analyse the need for psychosocial support and to evaluate the efficiency of treatment. The QSC-R23 contains 23 items (1 page) that describe potential distress in all areas of life in everyday language. Each problem includes to answers: does it apply at present and - if it does apply - to what extent does this problem cause distress? The range of the response categories varies between $0(=$ the problem does not apply to me $)$ and $5(=$ the problem applies to me and is a very big problem). The items are grouped into five homogeneous scales: psychosomatic complaints, fears, information deficits, everyday life restrictions, and social strains. The QSC-R23 was evaluated (convergent and discriminant validity, sensitivity to change, reliability) based on a data set containing data from $\mathrm{n}=3223$ patients.
Especially for the purpose of distress screening a short form of the QSC was developed, the QSC-R10. It is a 10 item version containing one dimension. It can be completed by cancer patients within a few minutes. The total score of this version is correlated $r=.95$ with the total score of the standard version (QSC-R23). We suggest a cut off score to indicate need for psychosocial support. An electronic version of the QSC-R10 is also available, the QSC-R10e. Patients answer the 10 items online on a computer. The result, including the cut off score can be seen immediately on the computer screen or an outprint. The total scores of the paper and the electronic version correlate $r=.98$. Pretests demonstrated that this version is feasible and acceptable even for older patients.

\section{IS018}

\section{Circulating tumor cells - Implications for diagnosis and therapy}

Müller V. ${ }^{1}$, Pantel K. ${ }^{2}$, Riethdorf $S .{ }^{2}$, Rack $B .{ }^{3}$, Janni $W .{ }^{3}$, Solomayer E. ${ }^{4}$, Fehm $T^{4}$

${ }^{1}$ Universitätsklinikum Eppendorf, Klinik für Gynäkologie, Hamburg; ${ }^{2}$ Universitätsklinikum Eppendorf, Institut für Tumorbiologie, Hamburg; ${ }^{3} \mathrm{LMU}$, Universitäts-Frauenklinik, München; ${ }^{4}$ Universitäts-Frauenklinik, Tübingen

Hematogenus tumor cell dissemination is known to be an early event during breast cancer progression. This early step in the metastatic cascade can be detected using modern immunocytochemical or molecular methods. Clinical studies demonstrated that the detection of disseminated tumor cells in the bone marrow of patients with primary breast cancer is a strong prognostic factor. This is an evidence for the biologic relevance of these cells. Despite of these findings, bone marrow aspiration is not widely established in clinical routine. Circulating tumor cells can be detected also in the blood. Blood sampling is easy to perform and repeated sampling is possible. The identification of patients at increased risk for recurrence in the context of adjuvant chemotherapy is an application of high clinical relevance. These patients might benefit from an additional "second-line" treatment, e.g. bisphosphonates or targeted therapies like anti-HER2 approaches or anti-angiogenetic drugs and therapeutic targets could be identified on residual tumor cells. Several translational research studies in Germany examine unsolved questions in this context and should help to improve treatment of breast cancer patients.

\section{IS019}

Differences between outpatient and inpatient arts therapy (AT)

\section{Seegenschmiedt M.H., Connert S.} Klinik für Radioonkologie, Essen

Aim of study: To describe different forms of behaviour of the participating patients - out- and inpatients - and elaborate the respective relevance of AT for the patients in their specific situation, as well as showing in what sense the integration of AT makes in the therapy treatment of patients with certain clinical pictures.

Patients and Methods: AT is offered in two different ways: inpatient during the acute treatment; outpatient during the aftercare. The data of the AT are collected in a psychosocial report sheet of the PSAPOH since 2005 and with the OPS number 9-401.4 - psychosocial individual number for 'Creative Therapies (arts, music etc)

(1) Inpatient AT is practiced since 1999. Group AT (120 minutes per week). Individual (50 minutes per week) in the hospital ward. In $2007 \mathrm{n}=181$ patients (136 f / $45 \mathrm{~m}$, average age 62,7) contacted AT: 77 oncological patients $(69 \mathrm{f} / 8 \mathrm{~m}), 45$ non- oncological, 59 diagnosis unknown. The participation is documented according to OPS -number: AT group 141, individual At 65. 8 male patients with the diagnosis tumor had no recommendation for their medical treatment plan. There were 24 pain patients $(13 \mathrm{f} / 11 \mathrm{~m})$ who had a recommendation for their AT treatment.

(2) Outpatient AT is practiced since 2003 (120 minutes per week), no individual Therapy being offered. In 2007 (39 days) $\mathrm{n}=12$ (12 f / $0 \mathrm{~m}$, average age 55,2) 9 oncological patients, 3 non - oncological patients. Participation documented according to OPS number 145. 
Results: The number of participants at the impatients and outpatient AT is almost equal according to the OPS number (in. 141/out.145). Inpatients only take part in AT for a short time, often only once or twice. Patients during the period of aftercare make use of the AT for a long period of time. Patients, who got a recommendation, find a way into AT more easily. Men emotionally benefit from the therapeutic situation. During the aftercare mostly women suffering from breast cancer have taken part in the outpatient AT - whereas men haven't so far. In the At setting they meet people alike and the find emotional and psychological backing. Not only does the picture but also the AT setting have a positive effect on the stability of the involved participants. By joining the AT groups for a long time the patients develop solidarity and confidence in each other because of their common activity of painting. After the death of one patient all of them attended the meetings, but with individual interruptions and all of them dealt with the subject 'death' in a different way.

Conclusion: The number of patients of the breast cancer center shows how the $\mathrm{S} 3$ guideline is realized. The fact that more male patients during the pain treatment take part in AT groups commend an integration of AT into medical treatment plans. As pain inpatients react in a positive way to the recommended AT, it is worth thinking to integrate AT systematically into the treatment plan of cancer patients with a secondary diagnosis of pain.

\section{IS020}

\section{Radiosensitization in radiation oncology}

\section{Baumann M., Zips D., Krause M.}

Universitätsklinikum Carl Gustav Carus Dresden, Strahlentherapie und Radioonkologie, Dresden

Background: Radiotherapy is highly efficient to kill cancer stem cells and can control tumours in many clinical situations. However the radiosensitivity of tumour surrounding normal tissues limits applicable radiation doses. Therefore approaches to specifically radiosensitize tumours have been tested over the last decades in preclinical investigations and clinical studies.

Methods: This presentation will review preclinical and clinical research on radiosensitization in radiation oncology and will give an outlook on future developments using biology driven approaches.

Results: Classical radiosensitization approaches have usually applied cytotoxic substances which mainly via additional cell kill have increased treatment intensity. Although the results of radiotherapy on average could be improved by combined radiochemotherapy, its use and future potential is limited due to increased normal tissue toxicity. New biologically active targeted drugs such as epidermal growth factor receptor (EGFR) inhibitors have the potential to directly radiosensitize tumour cells by modulation of e.g. signal transduction. Preclinical and first clinical data show promising results of such combined approaches. However, a considerable heterogeneity of the response of individual tumours to the combined therapy as well as of the activity of different classes of drugs has been observed. To understand the underlying mechanisms, further preclinical and clinical research is warranted. An alternative or additional biological approach is to indirectly radiosensitize tumour cells by modulation of the tumour microenvironment, i.e. by minimization of mediators of radioresistance. For either avenue of modern radiosensitization, radiotherapy specific research strategies are needed to explore interactions of drugs with radiation effects, to adapt the radiation doses and schedules, and to develop predictive tests which in future could lead to a more individualized anticancer therapy. These new developments need highest quality radiotherapy planning and application to be safely and effectively translated into clinical practice. Conclusion: Radiochemotherapy has moderately improved treatment results and has become current standard for radiosensitization in many clinical situations. However, its mechanisms of action are rather unspecific and its future potential appears limited by its toxicity. It is anticipated that novel biology-driven direct or indirect approaches of radiosensitization.will assume an increasing role in modern radiation oncology.

\section{IS021}

\section{Einflüsse von Rehabilitationssport auf die physischen, psychischen und psychosozialen Parameter von Patienten nach Prostatakarzinom, Evaluationsstudie}

\section{Baumann F. ${ }^{1}$, Schüle K. ${ }^{1}$, Bloch $W^{2}$}

${ }^{1}$ Deutsche Sporthochschule Köln, Institut für Rehabilitation und Behindertensport, Köln; ${ }^{2}$ Deutsche Sporthochschule Köln, Institut für Kreislaufforschung und Sportmedizin, Köln

Einleitung: Trotz der hohen Zahl an Neuerkrankungen pro Jahr (48.650), erscheint das Angebot supportiver Maßnahmen für die männlichen Patienten eher bescheiden [ RKI 2006]. Obgleich der schon langjährigen Erfahrung mit körperlichen Aktivitäten in der onkologischen Rehabilitation finden sich nur wenige Studien, die den Rehabilitationssport in der Krebsnachsorge evaluieren.

Problembesprechung: 1981 entstand in Köln die weltweit erste Krebsnachsorge-Sportgruppe [Schüle 1983]. Heute existieren in Deutschland knapp 700 Krebssportgruppen, an denen vorwiegend Brustkrebs betroffene Frauen teilnehmen. Mehrere Modellprojekte mit speziellen Angeboten für Männer und Frauen wurden nicht angenommen [Schüle 2006]. Demnach findet sich auch keine Literatur über die Wirksamkeit von Rehabilitationssport nach Prostatakarzinom und darüber hinaus nur sehr wenige Studie, die über eine Verbesserung der körperlichen Leistungsfähigkeit durch rehabilitative Maßnahmen berichten.

Die Ziele: In der multizentrischen, randomisierten, kontrollierten Präferenzstudie soll der Einfluss von Bewegungs-Aktivitäten auf die physische, psychische und psychosoziale Ebene des Patienten nach der Prostata-OP untersucht werden. Das übergeordnete Ziel dieser Untersuchung ist die Evaluierung des Rehabilitationssports mit prostataektomierten Patienten, in dem vom Gesetzgeber vorgegebenen Rahmen (\$44 SGB IX) sowie der nachhaltigen Gründung mehrere Prostata-Gruppen. So sollen durch gezielte Bewegung physische Komponenten wie Inkontinenz, erektile Dysfunktion und die allgemeine Leistungsfähigkeit (Hauptziel) verbessert werden. Des Weiteren werden psychische Größen wie Selbstverantwortung, Compliance, Krankheitsbewältigung, Angst, Depression und darüber hinaus Fatigue beobachtet, um damit vorangestellt die Entwicklung der Lebensqualität zu überprüfen.

Das Projekt und sein Ausblick: Es werden in einem Rekrutierungszeitraum von 18 Monaten 200 bis 300 prostataektomierte Patienten in die Untersuchung eingebunden. In dieser „comprehensive cohort study“ [Olschewski und Scheurlen 1985] sollen alle Teilnehmer ohne Ansehen Ihres Randomisierungsstatus nachbeobachtet werden. Falls ein Patient der Randomisierung zustimmt, wird ihm eine Studienintervention zufällig zugeteilt. Falls er der Randomisierung wegen starker Präferenz einer der beiden Interventionen nicht zustimmen kann, bekommt er die präferierte Behandlung und der Patient wird nachbeobachtet wie in einer Kohortenstudie. Die Kontrollgruppe bilden Probanden, die weniger als $60 \mathrm{~min}$ Sport pro Woche treiben. Die Trainingsgruppe nimmt über den gesamten Interventionszeitraum an einer ambulanten Rehabilitationssportgruppe teil. Das Programm sieht vor, dass die Teilnehmer über 18 Monate 1-mal pro Woche über $60 \mathrm{~min}$ in der Krebssportgruppe trainieren und dazu motiviert werden einen zweiten Sport-Termin wahrzunehmen.

\section{IS022}

\section{What can comprehensive cancer centers offer to recuit} and promote the best young brains for academic oncology?

\section{Baumann M., Ehninger G., Distler W., Herrmann T.,} Saeger H.-D., Schackert H.K., Wirth M.

Universitätsklinikum Carl Gustav Carus Dresden, mit Trennstrich von nächster Zeile trennen Universitäts-KrebsCentrum UCC, Dresden

Background: It is increasingly difficult to recruit young talents for academic oncology. This is not only a phenomenon in Germany but in many European countries. University-based multidisciplinary Comprehensive Cancer Centers by definition do not only focus on excellent patient care, but also run a variety of programs in basic, translational and clinical cancer research and have an important role in education and training. 
Methods: Typical structures of multidisciplinary Comprehensive Cancer Centers are reviewed to address the question whether special features of these institutions may be supportive for young talents to pursue a career in academic oncology.

Results: Although hypothetical at the present time, several aspects of Comprehensive Cancer Centers are anticipated to be useful for recruitment and academic promotion of young talented oncologist. Examples include among others excellent multidisciplinary training possibilities, day-by-day patient centered interdisciplinary interactions, inclusion of a maximum spectrum of oncology services into the training and specialization options, rotation systems for translational and clinical research periods, budgetary research support, a spectrum of high quality, investigator driven translational and clinical research options, integration in national and international networks, and excellent academic but also non-academic career options.

Conclusions: University-based Comprehensive Cancer Centers are anticipated to assume an important role in recruitment and promotion of young talented academic oncologists. However, experience with such models in Germany is still very limited and therefore this conclusion will remain a working hypothesis until firm data is available.

\section{IS023}

\section{Tumorscreening bei älteren Patienten: Mammakarzinom}

Kolb G.

St. Bonifatius Hospital, Lingen/Ems

Das altersabhängige Risiko an einem Mammakarzinom zu erkranken, steigt von rund 1:2.500 im Alter 30+ zu >1:10 für 80jährige an. Nichts desto trotz enden die meisten nationalen Mammakarzinom-Screening-Programme mit dem 60.ten Lebensjahr oder sogar früher. Deshalb wird die Mehrheit aller fortgeschrittenen Stadien, d. h. z. B. T4-Stadien des Mammakarzinoms bei älteren Frauen über 60 Jahren gefunden. Häufig wird angenommen, dass es die altersabhängige Komorbidität den evtl. Vorteil einer regelrechten und frühzeitigen Behandlung im Alter eliminiere. Zwei europaweit durchgeführte Studien $[1,2,3]$ haben jedoch gezeigt, dass eine saubere und stadiengerecht durchgeführte Chirurgie in Verbindung mit einer erforderlichen adjuvanten Chemotherapie bei älteren Frauen ebenso wirksam ist wie bei jüngeren Frauen. Die Komorbidität spielt nicht die Rolle, die man ihr früher beigemessen hat. Per Mammographie konnte gezeigt werden, dass die Mamma-CA-Mortalität signifikant abfällt in Abhängigkeit von einer regelmäßigen Durchführung eines Mammographie-Screenings aller Altersgruppen [4]. Es konnte sogar gezeigt werden, dass sowohl die Spezifität und Sensitivität der Mammographie speziell bei den älteren Frauen über 70 Jahren am höchsten ist.

Literatur

1. Mustacci $\mathrm{G}$ et al:Tamoxifen alone versus adjuvant tomoxifen for operable breast cancer of the elderly: Long-term results of the phase III randomized controlled multicenter GRETA trial. ANN Oncol 2003;14:414-420.

2. Fentiman IS et al: Treatment of operable breast cancer in the elderly: A randomised clinical trial EORTC 10850 comparing modified radical mastectomy with tumorectomy plus tamoxifen. Eur J Cancer 2003; 39:300-308.

3. Fentiman IS et al: Treatment of operable breast cancer in the elderly: A randomised clinical trial EORTC 10851 comparing tamoxifen alone with modified radical mastectomy. ibd 309-316.

4. Freedman G. M., Anderson P. R., Goldstein L. J., Hanlon A. L., Cianfrocca M. E., Millenson M. M., Mehren von M., Torosian M. H., Boraas M. C., Nicolaou N., Patchefsky A. S., Evers K. Routine Mammography Is Associated with Earlier Stage Disease and Greater Eligiblility for Breast Conversation in Breast Carcinoma Patients Age 40 Years and Older. Cancer 2003;98:918-925.

\section{IS024}

\section{Status QUO 2008: Basic documentation for psycho-oncology (PO-BADO)*}

\section{Marten-Mittag B. ${ }^{1}$, Huber B. ${ }^{2}$, Pirker $C .{ }^{1}$, Book K. ${ }^{1}$, Kiver $S .{ }^{3}$,} Herschbach $P^{3}$

${ }^{1}$ TU München, Psychosomatik, München; ${ }^{2}$ Klinikum Dritter Orden, München; ${ }^{3} \mathrm{TU}$ München, Psychosom./Psychosoz.Onkologie, München

Background: The Basic Documentation for Psycho-Oncology (PO-Bado) has become an established expert rating scale for the psychosocial distress of cancer patients in Germany. By now, three versions of this expert rating are available: the standard version, a shortform, and a disease specific version for breast cancer. Advancement and experiences in practical application will be presented.

PO-Bado standard version: Apart from documentation this version is frequently used for psycho-oncological screening in different clinical settings. To determine the need for psycho-oncological support a cutoff criterion was developed.

A user-friendly software was developed to record individual patient data and for statistical analyses of group data. This allows to compare the data with data from a PO-Bado reference sample containing nearly 7000 patient records. PO-Bado shortform (SF): Clinicians from acute clinical settings frequently expressed the need of a short psycho-oncological screening instrument that can be easily integrated into routine admission procedure. Hence, a shortform of the PO-Bado was developed that consists of 6 items. Psychometric evaluation was conducted. As for the PO-Bado standard version, a cut-off criterion is available to identify cancer patients in need for psycho-oncological support.

PO-Bado breastcancer (BC): The development of this disease specific version was also based on requirements of clinicians mainly from breast centers. The breast cancer specific tool includes all items from the standard version and additionally four breast cancer related items. Psychometric validation was carried out.

Also, a PO-Bado version for follow-up documentation is available and the standard version exists in different languages (English, French and Italian). Manuals are available for all versions.

*supported by Deutsche Arbeitsgemeinschaft für Psychosoziale Onkologie e.V. (dapo), Arbeitsgemeinschaft für Psychoonkologie (PSO) and Deutsche Krebshilfe e.V.

\section{IS025}

\section{Psycho-oncological care through psychological} consultation service at the Dresden breast cancer centre

\section{Ohms M. ${ }^{1}$, Schiebe $C{ }^{2}$}

${ }^{1}$ Städtisches Krankenhaus Dresden -Friedrichstadt, Klinik für Psychiatrie und Psychotherapie, Dresden; ${ }^{2}$ Städtisches Krankenhaus DresdenNeustadt, Klinik für Psychiatrie und Psychotherpaie, Dresden

The need for psycho-oncological care is expressed clearly in the guidelines given by the Deutsche Krebsgesellschaft and the Deutsche Gesellschaft für Senologie. Concerning its practical outworking there are major differences depending on location and experience. What we are presenting here is a care structure with therapeutic supplies and interdisciplinary networking in East German breast cancer centre.

The Dresden Breast Cancer Centre operates in two locations, Städtisches Krankenhaus Dresden Friedrichstadt and Städtisches Krankenhaus Neustadt. With each one of them, a psychologist who is on staff at the Clinic of Psychiatry and Psychotherapy working in the consultation-liason psychological service takes care of the breast cancer patients. Standard treatment is that each of the inpatients is consulted on site. Depending on the individual's needs we offer further consultations and meetings with family members. The consultations are primarily to help with crisis intervention, and to give strategies to cope, to mobilize resources, psycho-education, and to provide information about the psychosocial activities that are on offer, for instance if the need arises, motivation for further psycho-oncological/ psychotherapeutic treatment for outpatients. Because we work closely with a local group called Qualitätszirkel Psychoonkologie der KV Sachsen' there is seamless continuity 
for further care available from medical and psychological psychotherapists. The Dresden Breast Cancer Centre is also offering its former patients the opportunity to meet once a month over a six month period in an open forum which is led by psychotherapists. This is a structured psycho-education group which provides the opportunity to discuss specific given subjects and to receive more information. While we are furthering the interdisciplinary work and extending the network of in- and out- carers, especially in the framework of regular meetings of the social network, a greater degree of transparency can be reached by communication of the starting points and possiblities of the psycho-oncological work.

Questions for discussion: How can we reduce uncertainties and fears for both patients and the care team? How can interdisciplinary work and acceptance of psychosocial care within the team of physicians be improved?

\section{IS026 \\ Hereditary gastrointestinal polyposis syndromes: Recent improvements in classification and molecular genetic diagnostics}

\section{Aretz S.}

Universität Bonn, Institut für Humangenetik, Bonn

Hereditary gastrointestinal polyposis syndromes such as familial adenomatous polyposis (FAP), Peutz-Jeghers syndrome (PJS), or juvenile polyposis syndrome (JPS) are rare, however, the recognition and correct differential diagnosis is important given the high risk of gastrointestinal cancer and the effectiveness of the established surveillance programmes. In addition to the endoscopic results and histologic evaluation of the polyps molecular genetic analysis becomes increasingly valuable for diagnosis, risk prediction, and predictive testing. Our results are based on the examination of around 1250 unrelated patients with an adenomatous polyposis, 80 JPS families and 71 unrelated patients with a clinical diagnosis of PJS.

Recent developments in polyposis disorders include various areas: 1) The description of the $M U T Y H$-associated polyposis (MAP), an autosomal recessive adenomatous polyposis which represents an important differential diagnosis to attenuated and atypical FAP. The colorectal cancer risk is high, duodenal polyps were observed in one quarter of MAP patients, extraintestinal malignancies seem to be slightly increased with no predominant cancer type. In contrast to FAP the recurrence risk in offspring of MAP patients is low. 2) The implementation of the MLPA method allows for the identification of large genomic deletions in routine diagnostic settings. Our MLPA results demonstrate that large deletions represent $10-15 \%$ of germline mutations in polyposis genes, in PJS they even account for around $30 \%$ of all mutations detected. 3) The functional characterisation of rare genetic variants and the awareness of somatic mosaicism. 4) The delineation of novel genotype-phenotype correlations: in FAP large deletions are associated with a classic course of the disease; somatic mosaicism is frequently observed in FAP de novo cases and often accompanied by unexpected mild phenotypes. In our JPS patients gastric polyposis, gastric cancer, and hereditary hemorrhagic telangiectasia occur almost exclusively in SMAD4 mutation carriers.

Together, these developments raised the mutation detection rate considerably. However, in a substantial number of polyposis families the underlying genetic etiology of the disease remains to be uncovered. Hamartomatous polyposis syndromes may be a diagnostic challenge due to a wide distribution of different polyp types, thus, histopathological results must be critically interpreted.

The work was supported by the Deutsche Krebshilfe

\section{IS027}

\section{When and how to perform nutrition in cancer patients}

\section{Zürcher G}

Universitätsklinikum, Medizinische Klinik, Freiburg

Malnutrition and nutritional dysfunctions are common findings in cancer patients.Results are an increased morbidity and mortality and a reduced quality of life.As the symptoms indicative of malnutrition are present already at the time of diagnosis,or may emerge early with a still satisfactory nutritional status,medical dietary counseling should be included in the treatment plan from the beginning.Hence at weight loss of 5\% and more from healthy weight by every consultation nutritional examination should be done including examination of the energy uptake,and,if necessary,a medical dietary counseling should be given.During specific cancer-therapy in most cases patients could be nourished with normal meals or light normal meals given as variable mixed diet, individually modified by patients desires and needs.If the oral feeding is unsufficient ( $=$ oral intake under $60 \%$ of calculated needs expected for at least 10 days) or not feasible (= oral intake under $500 \mathrm{kcal} / \mathrm{d}$ expected at least for 5 days) an indication exits for artificial nutrition,primarily as enteral nutrition.For bedridden patients an energy requirement of $25 \mathrm{kcal} / \mathrm{kg} / \mathrm{d}$ is recommended,for ambulatory patients of 30-35 kcal/ $/ \mathrm{kg} / \mathrm{d}$.Fat intake should exceed $35 \%$ of total energy intake.The recommended protein intake is $1,2-1,5$ $\mathrm{g} / \mathrm{kg} / \mathrm{d}$. The recommended intake of vitamins and minerals correspond to the recommended dietary allowances (RDA) of the specialized organisations.The specific nutritional recommenda tions bevor and after operations, under chemo-and radiotherapy,under hematopoetic cell transplantation,outside cancer treatment and in the terminal phase are given in the evidence-based Guidelines on Enteral and Parenteral Nutrition of the DGEM (= Deutsche Gesellschaft für Ernährungsmedizin).They could be found under www.dgem.de.After cancer treatment a healthy diet should be taken.

\section{IS028}

\section{Screening for psychosocial distress using the NCCN distress thermometer}

\section{Mehnert A.}

Universitaetsklinikum Hamburg-Eppendorf, Institut fuer Medizinische Psychologie, Hamburg

Screening for psychosocial distress has become an important part of routine cancer care and is increasingly recommended in good practice guidelines. Given the small amount of time available during in- and outpatient cancer care, ultra short screening tools are needed to provide information about psychosocial distress and related problems in patients. The NCCN DistressThermometer is an ultra brief screening measure for psychological distress in cancer patients. Originally developed by the US National Comprehensive Cancer Network (NCCN), the German version consists of a visual analog scale ranging from $0-10$ on which a patient indicates how distressed he or she has been during the last week. In addition, a problem list provides information about possible causes of distress such as practical issues, partner and family problems, emotional problems, spiritual problems as well as a wide range of physical problems such as pain, fatigue or sleep problems. A score of 5 on the visual analog scale is recommended as an indicator that a patient is distressed and needs professional support. The problem list also indicates to which health care professionals a patient should be referred (e.g., psychological support, social work, spiritual/religious counseling or oncology). The German version has a sensitivity up to $84 \%$ and a specifity up to $47 \%$ when screening for moderate levels of anxiety or/and depression. The discriminating power of the Distress Thermometer was particularly good when screening for higher levels of depression or/and anxiety. Due to its high acceptance, its brevity and practice orientation, the NCCN Distress-Thermometer is a valuable ultra short screening to assess psychosocial distress in cancer patients. The presentation furthermore provides recommendations for the implementation of the screening in routine care and the use of interventions following the screening.

\section{IS029}

\section{Quality of life (QL) in Hodgkin's Disease (HD): Results from the german and european multicentre trials}

\section{Flechtner $\mathrm{H}$.}

Universität, KJPP, Magdeburg

Introduction: 1) To study and compare the quality of life (QoL) of patients on various QoL dimensions during, after therapy and during follow-up after the end of active treatment; 2) to identify longitudinal patterns of QoL dimensions during re-adaptation to normal life and 3) to obtain comparisons between treatment arms and prognostic groups.

Methods: Within the randomised trials, patients receive a QoL questionnaire for completion after chemotherapy/radiotherapy and during follow-up after 
the end of the first-line therapy. The EORTC QLQ C-30 is used for quality of life assessment, the MFI20 for assessment of fatigue, and further aspects include sexuality, specific side effects, and subjective retrospective evaluation of treatment. Overall, the instruments include 68 questions relating to 15 functional, symptom, and fatigue scales plus 17 additional single items, and 3 open questions. In addition, the German shortened version of the life situation questionnaire (LSQ) is used for the evaluation of objective parameters of the patients' life situation after end of treatment.

Results: For the current analysis about 18.000 questionnaires from 5000 patients enrolled into the trials are available. Replication of the psychometric properties of the scales revealed satisfactory results using factor analyses and reliability testing. Feasibility analysis showed a good acceptance of the questionnaire by both patients and physicians resulting in a high return rate during follow-up. Regarding the functional and fatigue scales, patients report a mixed pattern of responses but indicate severe limitations in their perceived QoL during the first years of follow-up. Emotional functioning recovers fully only in $50 \%$ of patients 3-5 years after end of treatment and $25 \%$ report constantly severe strain. The same is true for fatigue and global QoL. In physical functioning $85 \%$ recover fully and only 5\% report low functioning. In general, women report a lower QoL functioning and higher symptom scores over time than men. Patients with more advanced disease report lower functioning and higher symptom levels during follow-up.

Discussion: QoL assessment within multicentre trials in $\mathrm{HD}$ is feasible. QoL data from the reintegration process of patients into normal life during the first years of follow-up reveal substantial strain and limitations of QoL, particularly in specific subsets of patients. QoL assessment within the next trials generation is ongoing. Results regarding also socio-demographic variables and the longitudinal analysis of various subgroups will be presented in detail.

\section{IS030}

\section{Entscheidungskriterien zum Einsatz von Chemotherapie am Lebensende}

\section{Frickhofen $N$.}

HSK, Dr. Horst Schmidt Klinik, Innere Medizin III (Hämatologie, Onkologie, Palliativmedizin), Wiesbaden

Chemotherapie kann die beste Methode zur Kontrolle von Symptomen einer Tumorerkrankung sein. Beispiele sind allgemeines Krankheitsgefühl, Schwitzen oder Juckreiz durch ein Lymphom oder einen stark proliferierenden soliden Tumor, Beschwerden durch rezidivierende, nicht lokal behandelbare Ergüsse, Schmerzen durch nicht bestrahlbare, raumfordernde Metastasen oder Symptome durch Tumorinfiltration der Hirnhäute. Mit den neuen molekular gezielten Therapien wird sich dieses symptomkontrollierende Potential von "Chemotherapie“ eher noch erweitern.

Bei entsprechender Fachkunde gelingt die Abwägung zwischen positiven und negativen Wirkungen einer Chemotherapie Monate bis Jahre vor dem Lebensende meist gut. Mit der Annäherung an das Lebensende wird jedoch die Entscheidung schwieriger. Folgende systematischen Fragen helfen, in dieser Phase der Erkrankung zu einer patientengerechten Einschätzung zu kommen: (1) Liegt tatsächlich eine terminale Situation vor? Es kommt leider immer wieder vor, dass einem schwerst symptomatischen, wenig vorbehandelten Tumorpatienten in Unkenntnis guter Erfolgsaussichten einer Chemotherapie die Chance einer guten Symptomkontrolle und Wiederherstellung guter Lebensqualität durch eine Chemotherapie vorenthalten wird. (2) Gibt es eine auf den Tumor zielende Therapie, bei der die Aussichten auf eine Symptomkontrolle die Gefahr von Nebenwirkungen überwiegt, und wird der Patient dies voraussichtlich erleben? Chemotherapie braucht bei fortgeschrittenen Erkrankungen mindestens 1-2 Monate, um positive Wirkungen zu entfalten. Diese Zeit haben viele Patienten nicht. (3) Was will der Patient? Ist er ausreichend über die Chancen und Risiken einer Chemotherapie und die ihm verbleibende Zeit informiert? Patienten haben nicht selten falsche Vorstellungen von Chemotherapie. Es ist z.B. wichtig Ihnen zu verdeutlichen, dass selbst bei Wirksamkeit der Chemotherapie dieser positive Effekt in späten Phasen der Erkrankung nahezu immer nur wenige Wochen anhält

In den meisten Fällen werden sich informierte Patienten kurz vor dem Lebensende gegen eine Chemotherapie entscheiden, entweder wegen zu geringer Erfolgsaussichten oder wegen der begrenzten Zeitspanne, in der nur Nebenwirkungen und keine Wirkung zu erwarten sind. Es ist Aufgabe des Aztes, dem Patienten Zugang zu valider Informationen als Grundlage für eine solche Entscheidung zu beschaffen.

\section{IS031}

\section{Facial reconstruction using an individualized 3D technique - Directly from surface scanning to facial prosthesis}

\section{Mueller A.A. ${ }^{1,2}$, Paysan P. ${ }^{3}$, Schumacher R. ${ }^{4}$, Berg-Boerner B.-I. ${ }^{1,2}$,} Maurer J. ${ }^{1}$, Schkommodau E. ${ }^{4}$, Vetter $T^{3}{ }^{3}$, Zeilhofer H.-F. ${ }^{1,2}$, Schwenzer-Zimmerer $K^{5,2}$

${ }^{1}$ University Hospital Basle, Cranio-Maxillofacial Surgery, Switzerland; 2University of Basle, Hightech Research Centre of Cranio-Maxillofacial Surgery, Switzerland; ${ }^{3}$ University of Basle, Department of Informatics, Switzerland; ${ }^{4}$ University of Applied Sciences, Institute for Medical and Analytical Technologies, Northwestern Switzerland; ${ }^{5}$ University Hospital Basle, Cranio-Maxillofacial Surgery, Schweiz

Summary: In this pilot study we generated an individual facial reconstruction based on a statistical shape model. Then we transferred the planning directly into a biocompatible prosthesis by laser rapid prototyping.

Introduction: Facial defects due to trauma or extensive tumour surgery result in major physical and psychological implication for the patient. The morphological quality of the facial replacement depends on the clinical experience of the prosthesis technician. The conventional production process is labour-intensive and the conventional facial imprint is awkward for the patient. The aim of this pilot study was to improve these drawbacks of conventional prosthesis processing. Material and Methods: A 3D white light surface scan of the patients face is made. Then a Morphable Model was applied to reconstruct the nose in a statistical meaningful way. The Morphable Model is a statistical shape model learned from 3D face scans of 200 persons using Principal Component Analysis. For the reconstruction a non rigid registration algorithm is used to fit the face model to the 3D scan of the remaining facial parts.

The reconstruction was then manually combined with the scanned surface of the pathological region to form the 3D model of the prosthesis surface. Then the prosthesis surface had to be virtually materialised into a shell giving enough material to apply connectors. The edge was modified according to guidelines of the prosthesis technician. After this, the prosthesis was directly transferred into a biocompatible prosthesis using laser-sintering of Polyethlyen powder. The margins were hand finished on the patient.

Results: For the first time the Morphable Model was applied in a medical case to reconstruct a nose in a statistical meaningful way. The advantages of this method are that the reconstruction is not dependent on the artistic skills of the technician and it is suitable for region where mirroring is not possible like the nose.

The finished rapid prototyped prosthesis showed a good fitting of the prosthesis margins. The dimensions of the finished rapid prototyped prosthesis were compared to the virtual planning to show the deviation of the virtual planning and the definite shape of the prosthesis.

The shape of the remodelling was very realistic and close to the old patient photographs. Minor corrections had to be done by hand drilling. The colour fitting is presently unsatisfactory and has to be optimized.

\section{IS032}

\section{Molecular targeting in radiation oncology}

Baumann M., Dörfler A., Eicheler W., Gurtner K., Krause M., Schütze C., Yaromina A., Zips D.

Universitätsklinikum Carl Gustav Carus, Strahlentherapie und Radioonkologie, Dresden

Background: Molecular targeting is a rapidly evolving field of preclinical and clinical research in radiation oncology.

Materials and Methods: The presentation will review the rationale of molecular targeting in radiation oncology and the current status of translational and clinical research in this field.

Results: The aim of curative radiotherapy is to achieve permanent local tumor control which requires inactivation of all tumor stem cells, i.e. those cells able to form a recurrence. Molecular drugs, when given alone, have shown only little efficacy to kill tumor stem cells. In contrast, radiotherapy is a highly efficient modality for inactivation of tumor stem cells, and recurrences after high dose radiotherapy often occur from only one ore few surviving cells. Therefore radiotherapy offers a promising environment for integration of molecular targeted agents to increase the cure rates of cancer patients. Several 
preclinical investigations on molecular targeted drugs, particularly in the field of EGFR inhibition but also with cytotoxic antibodies or vascular-targeted approaches, have provided proof-of-principle that it is possible to specifically interfere in radiobiological mechanisms of radioresistance such as stem cell number, repair, repopulation or tumor hypoxia. Clinical trials, including a phase III multicentre trial on anti EGFR antibodies, are in accord with these preclinical investigations.

Conclusions: Molecular targeting combined with radiotherapy has demonstrated effectiveness in preclinical and clinical cancer research and is highly promising for further research in the coming years. In some instances molecular targeted drugs already today may be considered an appropriate option for clinical application.

\section{IS033 \\ Computer assisted quality of life diagnostic within psychooncological routine treatment}

\author{
Pirker C. ${ }^{1}$, Geinitz H. ${ }^{2}$, Berg P. ${ }^{1}$, Henrich G. ${ }^{1}$, Sehlen S. ${ }^{3}$, \\ Herschbach P. ${ }^{1}$ \\ ${ }^{1}$ Universität, Psychosomatik, München; ${ }^{2}$ Universität, Radioonkologie, \\ München; ${ }^{3}$ Universität LMU, Radioonkologie, München
}

Purpose: About 25\% of all cancer patients suffer from psychosocial distress that requires psycho-oncological treatment. Clinical experiences indicate that the percentage is even higher among the patients treated with radiotherapy $(33-42 \%)$. The objective of the study is to evaluate the acceptability and feasibility of a computer touchscreen technology as a method to screen cancer patients under radiotherapy for psychosocial support.

Method: A questionnaire was computed on tablet PCs for specifically accessing psychological distress in radiooncological patients (StressIndex Radioonkologie, SIRO, Sehlen et al. 2003).

While waiting for radiotherapy the patients were asked by RTAs to complete the SIRO. A psychooncologic report was printed immediately and given to the doctors seeing the patients. The satisfaction of doctors and RTAs with this procedure including the practical implementation and its benefit was surveyed.

Results: Experiences show that the implementation of the procedure into daily routine is very complex and has also an important influence on the perceived importance of psychosocial aspects within treatment process. The study included 142 patients. $99,2 \%$ of the patients had no problems in handling the questionnaire on tablet PC. 93,3\% of the doctors considered the psychooncologic report easy to read. $3,7 \%$ of the RTAs estimated the complexity of computer version too high on average they needed 6.36 minutes per patient. The costs for each person were 3.51 Euro.

Taken together, the implementation of a computer assisted QoL diagnostic procedure is feasible and beneficial, even though the consideration of psychosocial distress requires special preparation for clinical staff.

Acknowledgements: The project was funded by the Deutsche Krebshilfe e.V.

\section{IS034}

\section{S3-guidelines - Breast cancer: Pathology}

\section{Lebeau A.}

Universität, Pathologie, Hamburg

Aims: Within the multidisciplinary process of clarifying palpable or nonpalpable abnormalities, it's the role of the pathologist to provide that information crucial for the adequate management of the patient. Since the publication of the German S3-guidelines for the early detection of breast cancer (www.senologie.org) and for the diagnosis and therapy of breast cancer in women (www.krebsgesellschaft.de) in 2003 and 2004, respectively, there have been new data published to update recommendations in several areas concerning the local and systemic treatment of DCIS and invasive breast cancer.

Methods: Both guidelines have been updated by focusing attention on new data in the more controversial areas regarding HER2 testing, sentinel lymph node biopsy, radiotherapy, and systemic treatment of invasive breast cancer.

Results and Conclusions: Updates concerning the pathological determination of necessary and relevant criteria to support the adequate and evidence based management of the patients are presented.

\section{IS035}

Implications of tumour biological models for cancer therapy

\section{Mader R.}

Medizinische Universität Wien, Klinische Abteilung für Onkologie, Wien

Rational approaches to anticancer treatment are dependent on the comprehensive understanding of the biological processes underlying cancer. Although rational anticancer drug design started very early (e.g. cyclophosphamide or 5fluorouracil), the integration of distinct tumourigenic mechanisms into models of cancer development enables us to bridge the gap between tumour biology and cancer therapy. Using colorectal cancer as a paradigm, the three most recent models of tumourigenesis had an enormous impact on clinical approaches: the colorectal adenoma-carcinoma sequence with escalating mutations as driving force, the epigenetic model of tumourigenesis, and the cancer stem cell hypothesis. Although the mutational status of $K$-ras or $p 53$ had little predictive power for the therapy of colon carcinoma with 5-fluorouracil, other mutation associated mechanisms such as angiogenesis have set the stage for therapeutic interventions including bevacizumab and matrix metalloproteinase inhibitors. The emergence of epigenetic regulations as a very early event in the adenoma-carcinoma sequence has prompted the development of new agents towards these targets such as 5-aza-2'-desoxycytidin or zebularine (inhibitors of DNA-methyltransferase) and suberoylanilide hydroxamic acid or PXD101 (inhibitors of histone deacetylase). These intracellular models have been completed by the stem cell hypothesis stressing a whole cell population as carrier of the malignant potential. As the most recent of our models, there is urgent need for scientific evidence as figures are often divergent, if not contradictory (number or tumour initiating stem cells, marker molecules, relevant experimental models, ...). These models are a starting point for the integrative view of cancer as a disease involving processes at the cellular, the tissue and the organ level including the complex communication between the tumour environment and the malignancy. Among these regulatory molecules, micro-RNAs are very promising targets. The translation of this knowledge will depend on the cooperation between experimental and clinical oncology and the rigorous validation of these targets in prospective clinical trials.

\section{IS036}

Multifactorial prevention, risk of cancer and physical activity

\section{Steindorf $K$.}

Deutsches Krebsforschungszentrum, AG Umweltepidemiologie, Heidelberg

In its early days, research on protective effects of physical activity focussed on cardiovascular endpoints. In the 1980s, epidemiologists and other basic scientists started to also investigate the effects of physical activity on the risk of cancer. It appeared that a differentiated tumour-specific view has to be taken in order to describe the effects. This presentation will give an overview on the current knowledge for various cancer sites. It will incorporate several epidemiologic studies performed in our research unit for colorectal, breast and lung cancer. Furthermore, possible biologic mechanisms will be discussed. It will be shown that increased physical activity is a protective factor for specific tumours. The effects are remarkably stable over different study situations and the effect sizes are substantial. Physically active persons have a 40 to 50 percent decreased relative risk for colon cancer compared to inactive persons. The relative risk for postmenopausal breast cancer is decreased on average by 20 to 40 percent. Protective effects for other tumours, for example for endometrial and prostate cancer, are classified as possible. Besides these clear results several important questions remain open: less studied tumours need extended attention, the underlying biologic mechanisms need further investigation, and it is still unclear whether there are specific life or age periods in which physical activity is specifically effective to reduce the cancer risk, an important issue for the planning of interventional programs. Another open point is whether there are interactions with dietary factors, and whether the observed effects for physical activity are mostly explainable through the different dietary habits of active subjects. In this presentation it will be shown that there is currently no scientific basis to believe that the observed protective effects of physical activity only mirror the effects from a healthier diet. Available data suggest an independent protective effect of physical activity.

Colon and breast cancer belong to the most frequent incident tumours in Germany. Thus, the relative risk reductions by physical activity transform into 
substantial absolute numbers of cancer cases implying a great relevance from the public health perspective. This relevant potential of physical activity as a clear cancer-preventive factor could be better used in future for primary prevention and intervention programs in the engagement against cancer.

\section{IS037}

\section{Follow-up care for breast cancer - Guideline and study}

Heidemann E. ${ }^{1}$, Meisner $C^{2}{ }^{2}$, Brinkmann F. ${ }^{1}$, Rössle S. ${ }^{1}$

${ }^{1}$ Onkologischer Schwerpunkt Stuttgart e.V., Stuttgart; ${ }^{2}$ Universität

Tübingen, Institut für Medzinische Biometrie, Tübingen

Objects: Symptom-oriented follow-up care has been incorporated into the S3 guideline and the disease management programme (DMP) for breast cancer on a national scale. Internationally, this has been the standard for some time. In a study symptom-oriented and apparatus-oriented follow-up care were compared over a follow-up observation period of five years following primary therapyin regard to the overall time of survival and the recurrence time, in Germany.

Methods: Reviews of studies and literature; patient surveys regarding the choice of follow-up care form, and prospective, comparative, multi-centre, non-randomised cohort study from 1995 to 2005 on 665 patients.

Results: The results of the study confirm that regularly performed imaging procedures and laboratory investigations have no significant influence on the survival of breast cancer patients following curative primary therapy and support the introduction of symptom-oriented follow-up treatment in routine care. Discussions indicate that, at the present time, the persons affected continue to request, above all apparatus-oriented, follow-up care.

Conclusion: Symptom-oriented follow-up care has required a long time to gain acceptance in the form of guidelines and in practice and does not always conform to the need for reassurance of different patient characters. Practice and study at the OSP Stuttgart have shown that quality management of follow-up care offers both patients and physicians the required assurance and can be successfully integrated in the disease management programme for breast cancer.

*Comprehensive Cancer Centre of Stuttgart.

\section{IS038}

The Hornheide Screening Instrument (HSI) as an assessment tool for need of psychosocial care in cancer patients

\section{Strittmatter G. ${ }^{1}$, Gerhards $F^{2}$ \\ ${ }^{1}$ Fachklinik Hornheide, Psychosoziale Onkologie, Münster; ${ }^{2}$ Universität, Klinische Psychologie und Psychotherapie, Trier}

Objective: The Hornheide Screening Instrument (HSI) is the latest development of Hornheide instruments for identifying tumour patients who need special psychosocial care. The HSI consists of 7 questions which are put during an initial conversation with the patient (interview version) or in written form (questionnaire version). We investigated the performance of the HSI interview version as well as the questionnaire form and analyzed the reliability and validity of the HSI

Methods: In a first study with 122 consecutive inpatients with defined skin and facial tumours the HSI interview was conducted, and patients filled out the Hornheide questionnaire (HQ). The HQ was looked at as a "gold standard for determining the need for psychosocial care. By means of a discriminant analysis the mathematical function optimally parting patients with and without need for psychosocial care (according to their HQ scores) was calculated.

In a second and third study with 295 oncological inpatients and 143 outpatients the performance and dimensionality of the HSI questionnaire version was analyzed. All patients filled out the HSI questionnaire as well as the German version of the Hospital Anxiety and Depression Scale (HADS; Herrmann et al., 1995).

Results: The reliability of the HSI interview version was a $=.74$. Nearly $79 \%$ of the patients in need of psychosocial care and $89 \%$ of those without need for such care were correctly identified on the basis of their interview responses. Altogether, $86 \%$ of all cases were correctly classified by means the discriminant function that had been generated.

The reliability of the HSI questionnaire version was a $=.60$. A principal component analysis of the questionnaire data resulted in a three factorial solution that explained $61.4 \%$ (study II) and $61.9 \%$ (study III) of the total variance. The correlation of the HSI total score and the HADS total score or the HADS scores for anxiety and depression varied between .50 and .55 , all coefficients were highly significant. A HSI total score $\geq 4$ proved to be a fairly good indicator of the need for psychosocial care: For this HIS criterion sensitivity scores of 0.68 or 0.62 (studies II and III) and specificity scores of 0.76 or 0.75 were calculated using the cut-off scores recommended for the German HADS version as a "gold standard" for determining the need for psychosocial care. Conclusions: The HSI is a practicable, fairly reliable and valid screening instrument for identifying oncological patients in need of psychosocial care. The instrument can be used in form of an interview as well as in a questionnaire format and is suitable for tumour patients independent of the kind of diagnosis, the stage of the disease or the kind of treatment.

\section{IS039}

Impact of physical activity vs relaxation intervention (autogenes training) in women with breast cancer in an adjuvant chemotherapy setting. Results of a randomised study

\section{Kleine-Tebbe A., Dimeo F.}

Universität, Berlin

Background: Epidemiological data indicate that physical activity (PA) is associated with a decreased risk for breast cancer. Few studies suggested that physically active breast cancer survivors are at lower risk of recurrence compared with inactive survivors. We investigated the feasibility of an early additional PA intervention compared a relaxation intervention (Autogenes Training, AT) in a clinical trail for breast cancer patients with adjuvant chemotherapy. We collected data to evaluate the safety, tolerance and toxicity as well as quality of life.

Methods: After randomisation while on anthracyclin based chemotherapy we distribute among two groups for either PA or AT intervention. The women in the PA group were instructed to run 3 times per week with assistance of a health care trainer. In the AT group women were introduced to this method and were asked to repeat it 3 times a week.

Results: Thirtysix women were evaluated. The results show that moderate PA is an effective, safe and suitable additional intervention to maintain the physical and emotional capability in women with breast cancer. There was less toxicity due to chemotherapy in the PA intervention arm compared to the AT arm. There were transient changes in biomarkers and immunofunction in both arms which were comparable. The data from the cytokines suggest that PA does not lead to an exhaustion of cytokine resources.

Conclusion: Women with breast cancer are interested in participating in physical activity intervention studies. Adjuvant chemotherapy in breast cancer patients does not invariably lead to of deterioration of body function and impaired quality of life when PA intervention ist used additional. Further studies are necessary to determine the impact of physical activity on endpoints related to breast cancer risk and therapy.

\section{IS040}

Trends in alternative cancer therapy 2007: What patients want to know

\section{Hiller $B$}

Krebsinformationsdienst, Heidelberg

Complementary and alternative methods (CAM) are a source of hope for many cancer patients. Which methods were of interest to German patients, their relatives and friends in 2007?

Materials and Methods: The German Cancer Information Service (Krebsinformationsdienst) at the German Cancer Research Center (Deutsches Krebsforschungszentrum) is a service giving science based information to the public via phone, e-mail and internet. In 2007, an evaluation of the almost 6.500 individual e-mails reaching krebsinformationsdienst@dkfz.de provided data on the users' questions and their personal beliefs concerning alternative cancer treatment (CAM).

Results: German cancer patients and their relatives categorize a wide spectrum as ,alternative medicine“, from mistletoe to ethnic medicine. The 
requests for phytotherapy, "holistic" or "complementary" methods to the Cancer Information Service, however, have decreased from more than $20 \%$ of the overall questions in the early 90s down to $12,4 \%$ CAM in 2007. Today many questions concern unproven methods, which mimic clinical trials and claim to be science based, even when no data on their effectiveness are available. These methods could not be identified as unproven or sometimes even illegal by patients and most physicians in 2007. A similar problem arises from the growing international market for nutritional supplements: Most users of the Cancer Information Service in 2007 were not aware that there was a difference between prescription drugs and dietary supplements, and that some of them, like soy preparations or mega doses of vitamins, might even have harmful side effects or lead to interactions with standard cancer therapy.

Conclusions: Most cancer patients and their relatives contacting the Cancer Information Service do not seek an alternative to standard treatment in general. They are looking for any option seeming to offer more choices in treatment, less side effects, more hope and, in a growing number, an early access to "science and research“, even if they have to pay for it. To come to a decision about the use of CAM, they need unbiased and evidence based information. To protect patients from fraud, however, it is not appropriate to limit the scientific discussion about unproven methods to the usual CAM definitions.

\section{IS041}

\section{Explosion of knowledge in cancer medicine - Consequences for patients and physicians}

\section{Gebest H.-J.}

Deutsches Krebsforschungszentrum, Krebsinformationsdienst, Heidelberg

Since the last decade the amount of knowledge about cancer, diagnosis and treatment has been increasing enormously. This development has several different aspects:

1. Cancer in general is a very complex issue and needs comprehensible explanations

2. Abundant information about cancer is available for everybody who has access to the internet

3. Patients and relatives are faced with a variety of confusing information not knowing which piece of information can be trusted in

4. Patients gather plenty of information about their disease in order to understand their disease and discuss treatment options and other illness related issues with their doctors

5. Patients and physicians are confronted with an increasingly complex array of possibilities for cancer diagnosis and cancer treatment

6. Even for physicians it is becoming more difficult to keep track of new developments in cancer medicine

7. There is a steadily growing need for unbiased, high-quality information to both the public and medicals professionals

8. In addition to a Cancer Information Service for the public the time has come now to launch a Cancer Information Service for Physicians

\section{IS042}

\section{Psycho-oncological care in breast centre in cooperation with resident psychotherapists}

\section{Reuter E. ${ }^{1}$, Schwickerath J. ${ }^{2}$}

${ }^{1}$ Praxis für Psychotherapie, Olpe; ${ }^{2}$ St. Martinus-Hospital, Olpe

Since 1999 - several years before the certified Breast Centre Siegen-Olpe was established - there has already been a consultation service between the local gynaecological hospital and a nearby psychotherapy practice with emphasis on psycho-oncology.

In 2001 a non-profit association "Kompetenz gegen Brustkrebs"(Competence against Breast Cancer) was established by persons affected, regional doctors and scientists. Among others, this association is responsible for the organisation of the so-called "Patient Seminars".

In 2003 a study on the acceptance and usage of psycho-social options (consultation hours, patient training, and individual psycho-therapy) during acute and aftercare periods was started. This study was promoted by the Deutsche Krebshilfe e.V. (German Cancer Aid).

In 2006 the existing consultation service evolved into a regular liaison service with its individual offers being stipulated in a cooperation contract.

Currently the following structures and cost arrangements are available:

- 2 visits of the psycho-oncologist per week with patients in the gynaecology hospital facing their first cancer diagnosis

- Regular advanced training of nurses and doctors (3 times per annum)

- Offer for a short-term therapy (of up to 10 hours) on disease coping (especially for traumatized patients and patients in the neo-adjuvant phase)

- These services will be paid by the hospital.

- Twice a year 18-hour patient seminars on medical, psychological, naturopathic, sociological and social-legally issues. Invited speakers provide information and

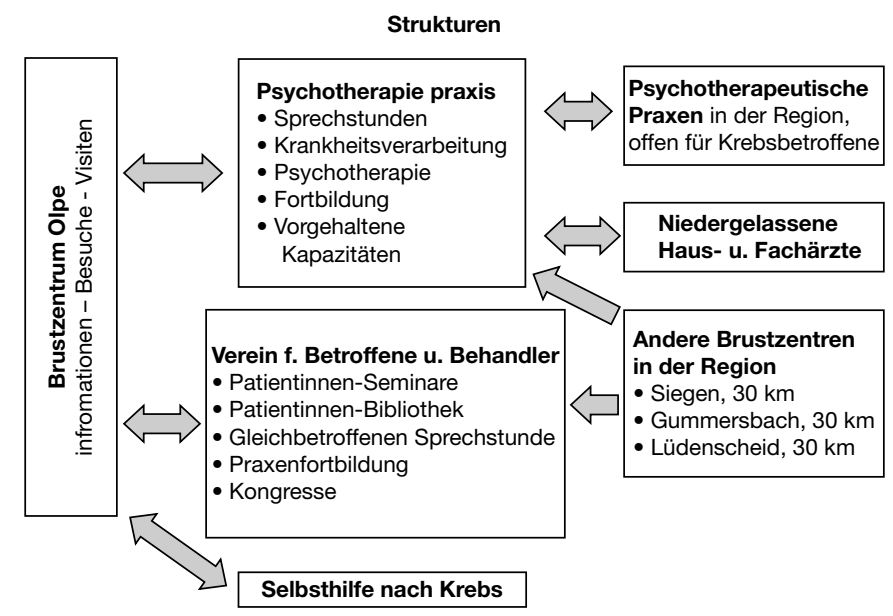

Table 1: Gesamtgruppe Mamma-Ca. Erstbefund 2004/05 + 2006/07; Frauenklinik Olpe; N = 314; Durchschnittsalter 59,21 Jahre (for abstract ISO42)

\begin{tabular}{|c|c|c|c|c|c|c|c|c|}
\hline \multirow[t]{2}{*}{ Altersgruppe (\%) } & \multicolumn{2}{|l|}{ Sprechstunde $^{\mathrm{a}}$} & \multirow[t]{2}{*}{ Diagnostik (\%) } & \multicolumn{2}{|c|}{ Belastung $^{\text {b }}$} & \multirow{2}{*}{$\begin{array}{l}\text { Bewältigungs- } \\
\text { kompetenz }^{\mathrm{c}}\end{array}$} & \multicolumn{2}{|l|}{ Teilnahme an ${ }^{d}$} \\
\hline & erwünscht (\%) & unerwünscht $(\%)$ & & Angst & Depression & & Seminar (\%) & $\operatorname{EP}(\%)$ \\
\hline $\begin{array}{l}\leq 50 \text { Jahre } \\
N=86(27,4 \%)\end{array}$ & 70,93 & 29,07 & 83,73 & 9,74 & 5,93 & 53,20 & 23,25 & 26,74 \\
\hline $\begin{array}{l}51 \text { - } 65 \text { Jahre } \\
N=123(39,2 \%)\end{array}$ & 60,16 & 39,84 & 78,86 & 8,83 & 5,71 & 60,59 & 17,07 & 17,88 \\
\hline $\begin{array}{l}66 \text { - } 80 \text { Jahre } \\
\mathbf{N}=87(27,7 \%)\end{array}$ & 47,13 & 52,87 & 71,26 & 6,34 & 5,39 & 58,59 & 1,1 & 4,59 \\
\hline $\begin{array}{l}>80 \text { Jahre } \\
N=18(5,7 \%)\end{array}$ & 38,88 & 61,12 & 61,11 & 5,69 & 4,84 & 73,60 & 5,5 & $0 \%$ \\
\hline \multicolumn{9}{|c|}{$\begin{array}{l}\text { aSprechstunde im Akutkrankenhaus } \\
\text { bmittlere Angst- und Depressionsbelastung (HADS): Cut-off Werte: normal }<8 \text {, fraglich } 8-10 \text {, hoch }>10 \text {. Erhoben ca. } 7 \text { Tage nach Erstdiagnose } \\
{ }^{\mathrm{c}} \text { mittlere Bewältigungskompetenz (SOC-L9): gering }=\mathrm{PR}<25 \text {, normal }=\text { PR } 25-75 \text {, hoch }=\mathrm{PR}>75 \\
{ }^{\mathrm{d} S} \text { Seminar- und Einzelpsychotherapiebeginn ca. } 3 \text { Monate nach Erstdiagnose }\end{array}$} \\
\hline
\end{tabular}


answer questions - fee for seminars required from patients - supported by the health insurance companies and the association (with hardship provisions)

- Regular individual psychotherapy sessions (approx. 40 hours) - health insurance companies pay costs.

We describe processes and contents of the individual psycho-social interventions as well as the actual number of cases, using the services. Also psychic parameters of persons affected, age pattern and conditions of the medical systems, which present the described clinical pathways.

Furthermore personnel, structural and procedural qualifications of the psychotherapy practice to meet the needs of the breast centre.

\section{IS043 \\ Überleben nach Krebs - Ergebnisse epidemiologischer Krebsregister}

\section{Kraywinkel K. ${ }^{1}$, Nennecke A. ${ }^{2}$, Holleczek B. ${ }^{3}$, Hense H.-W. ${ }^{4}$}

${ }^{1}$ Epidemiologisches Krebsregister NRW, Münster; ${ }^{2}$ Hamburgisches Krebsregister, Hamburg; ${ }^{3}$ Epidemiologisches Krebsregister Saarland, Saarbrücken;

${ }^{4}$ Universität Münster, Institut für Epidemiologie und Sozialmedizin , Münster

Hintergrund: Gerade bei Krebserkrankungen sind Überlebensraten ein wichtiges Kriterium für die Versorgungsqualität auf Bevölkerungsebene. In Epidemiologischen Krebsregistern sind Überlebensraten für bestimmte Regionen mit überschaubarem Aufwand messbar, da das Ersterkrankungsdatum obligater Bestandteil der Inzidenzmeldung ist und in der Regel eine Gesetzesgrundlage für eine Erfassung der Sterbefälle mittels Todesbescheinigungen und Meldeamtsdaten besteht.Voraussetzung für eine valide Bestimmung sind hierbei eine ausreichende Vollzähligkeit, gute Datenqualität sowie ein vollständiger Mortalitätsabgleich.

Ziel: In zahlreichen Publikationen und auch im Rahmen des EUROCAREProjekts sind für Deutschland bisher fast ausschließlich die Daten aus dem Saarländischen Krebsregister herangezogen worden. Inzwischen haben jedoch mehrere andere Krebsregister in Deutschland eine ausreichende Vollzähligkeit und Beobachtungsdauer aufzuweisen, so dass Fragen der Vergleichbarkeit von Einzelergebnissen einerseits sowie gemeinsamer bzw. gepoolter Auswertungen anderseits anstehen.

Methode: Eine Arbeitsgruppe der Gesellschaft Epidemiologischer Krebsregister in Deutschland hat daher schon 2006 begonnen, sich mit den methodischen Problemen der Überlebenszeitanalyse aus Krebsregisterdaten zu befassen. Wichtige Themen waren insbesondere der Vergleich unterschiedlicher Berechnungsmethoden bzw. Software-Anwendungen, der Einfluss unterschiedlicher Sterbetafeln zur Berechnung des relativen Überlebens und die Einigung auf einheitliche Ein- und Ausschlusskriterien.

Ergebnisse: Zum Redaktionsschluss der 6. Auflage der Broschüre „Krebs in Deutschland“" waren noch nicht alle methodischen Fragen abschließend geklärt, sodass hierfür letztmalig ausschließlich Überlebensraten aus dem Saarland herangezogen wurden. In naher Zukunft sind jedoch Publikationen von Überlebensraten aus mehreren deutschen Krebsregistern zu erwarten.

Exemplarisch berechneten wir relative Überlebensraten zum Brustkrebs bei Frauen aus den Daten der Krebsregister des Saarlandes, des Regierungsbezirks Münsters und der Stadt Hamburg mit Hilfe des Periodenansatzes, der eine valide Schätzung der aktuellen Überlebenschancen liefert. Die Ergebnisse aus den einzelnen Registern zeigten sowohl nach 5 Jahren (relatives Überleben $82 \%-84 \%)$ als auch nach 10 Jahren $(73 \%$ - 75\%) eine hohe Übereinstimmung, auch die Stratifizierung nach Erkrankungsstadien (UICC) erbrachte sehr ähnliche Ergebnisse.

Fazit: In Zukunft werden die epidemiologischen Krebsregister in Deutschland mit der Veröffentlichung auch regionaler Überlebensraten nach Krebserkrankung einen wichtigen Beitrag zur Messung der Versorgungsqualität von Krebspatientinnen und -patienten liefern können.

\section{IS044}

\section{Onkologische Komplementärmedizin in einem erweiterten supportiven Konzept}

Holzhauer $P$

Veramed-Klinik, Onkologie, Brannenburg

Komplementärmedizin in der Onkologie wird aus den jeweils unterschiedlichen Sichtweisen der Patienten und der sie betreuenden Ärzte häufig kontrovers beurteilt und diskutiert. Viele Patienten und ihre Angehörigen suchen im Angesicht der oft schicksalhaften Krebserkrankung nach neuen, gelegentlich auch unkonventionellen Wegen der Hilfe. Neben medizinischen Informationen suchen sie nach Verständnis, Empathie und patientennaher Kommunikation. An dieser Schnittstelle trifft die krankheitsbezogene Ausrichtung der klassischen Schulmedizin auf die salutogenetisch orientierten Selbsthilfekonzepte der Patienten, die eigene Ressourcen zur Gesundung und Gesunderhaltung einbringen möchten. Aus dieser scheinbaren Polarität heraus definiert sich eine moderne Komplementärmedizin, die sowohl Aspekte der Unterstützung der Selbstheilung, als auch Aspekte der Ergänzung und Optimierung einer konventionellen onkologischen Therapie aufgreift und integriert. Komplementärmedizin ist nie eine Alternative, sondern immer nur eine Ergänzung. Der Schutz der Patienten vor den Folgen einer nicht gerechtfertigten Polypragmasie steht dabei immer im Vordergrund. Dazu ist eine kompetente Kenntnis der vielfältigen, oft unüberschaubaren Methoden erforderlich. Hier setzt die moderne evidenzbasierte komplementäre Onkologie an. Als erweiterte supportive, immer flankierende Maßnahme der konventionellen Basistherapie haben sich mittlerweile zahlreiche Methoden der Komplementärmedizin, unter dem zunehmenden Evidenzdruck der modernen Medizin, für den klinischen Einsatz qualifiziert. Diese Behandlungsmethoden sind gekennzeichnet durch zunehmende Evaluation sowie eine hohe Akzeptanz durch die Patienten. Besonders hervorzuheben sind die neueren Forschungsergebnisse aus den Bereichen der Therapie mit anorganischem Selen, dem Vitaminoid L-Carnitin und der Einsatz der Misteltherapie als eine der Therapieoptionen des tumorbezogenen Fatigue-Syndroms. Im Vortrag wird eine Auswahl geeigneter praktischer Einsatzmöglichkeiten aus diesen Bereichen dargestellt. Die aktuelle und zukünftige Ausrichtung der komplementären Onkologie sollte der weiteren wissenschaftlichen Überprüfung geeigneter Methoden und Substanzen höchste Priorität einräumen.

\section{IS045}

Hemochromatosis and hemosiderosis: Clinics and therapy

\section{Nielsen $P$.}

Universitätsklinikum Hamburg-Eppendorf, Zentrum für Experimentelle Medizin, Hamburg

Iron is an essential trace element involved in important metabolic reactions. Iron deficiency in humans is still a global medical problem. Unlike with most other trace elements, overloading with iron is also possible and these diseases are also very frequent.

The iron induced formation of reactive radicals is frequently attributed to the clinical symptoms of iron overload diseases in the liver (fibrosis, cirrhosis, liver cancer), pancreas (diabetes mellitus), heart (cardiomyopathy), or endocrine systems (growth retardation, infertility), etc.

Up to date four forms of a genetic iron overload (hereditary hemochromatosis) have been identified. In Northern Europe, only the type1 (= HFE-associated) hemochromatosis is of practical relevance, whereas other forms are rare. 1 out of 200-300 is homozygote for a single mutation (C282Y) in the HFE-gene of chromosome 6 . The function of the HFE-proteins is not fully understood but it must be involved in the synthesis of a peptide in the liver named hepcidin. Hepcidin represents the main regulatory hormone in iron metabolism and seems to have also many other functions. Hepcidin secreted into the plasma inhibits the uptake of food iron. Patients with hemochromatosis develop a progressive organ siderosis. What is not clear is the clinical variability of hemochromatosis. Only some patients develop the typical "text-book-symptoms" ("bronze-diabetes": liver cirrhosis, diabetes, skin coloration). Most patients diagnosed today have little or even no clinical symptoms. Nevertheless, all adult patients diagnosed should be treated by exhaustive phlebotomies in order to minimize the risk for the development of iron induced organ damages. In secondary forms of iron overload (hemosiderosis), the increase of iron absorption ("iron-loading anemias") and/or chronic blood transfusions lead also to a progressive iron overload which limits life-expectancies. Patients die from heart failure, diabetes or liver cirrhosis. The iron chelator deferoxamine $\left(\right.$ Desferal $\left.^{\circledR}\right)$, introduced in the 1970th , has clearly shown is life-saving properties in many patients with iron overload world-wide. However, the parenteral application is demanding for the patients. Some experience exists also concerning two oral drugs which are available (deferipron, Ferriprox ${ }^{\circledR}$; very recently, deferasirox, Exjade ${ }^{\circledR}$ ). These drugs seem to have advantages in some patients, but more long-term data are needed. Future developments could favour also the synergistic combination of different chelators. 


\section{IS046}

\section{Breast cancer - Clinical part}

Kaufmann $M$.

Universitätsklinikum, Frankfurt/M.

Breast Cancer is heterogeneous and chronic disease with early haematological micrometastases in most cases.

In general the disease is defined as endocrine responsive and -nonresponsive as well as HER-2 neu positive and negative cancer in pre- and postmenopausal women.

This is the basis for the understanding of our todays treatment strategies. Breast cancer is the leading cause of cancer death in women worldwide.

The estimated lifetime risk is 1 in $8-9$ in the western world.

In Germany more than 55.000 new cases are diagnosed.

The incidence may be increased by factors like: Higher prevalence of obesity, earlier menarche, delayed first pregnancy or nulliparity, increased use of hormone replacement therapy, greater alcohol consumption and aging female population.

The incidence rate is increasing, however, the mortality at ages 35-69 is decreasing. Risk of mortality is just half for women $<50$ years and is reduced by one third for women $>50$ years compared to patients of the last generation. (acc. overview analyses, R. Peto, Oxford)

Besides adjuvant and neoadjuvant cytotoxic and endocrine systemic treatments, early detection and screening are relevant for this highly positive progress.

We have now learned not to treat the risk of breast cancer patients but the tumor. For clinical routine work tumor characterisation is mainly performed by pathologists.

In contrast to endocrine therapies there are so far no predictive factors available to decide who will benefit from cytotoxic chemotherapy and which drugs should be used.

Besides old targeted therapies new treatment options are possible, which will lead to further better outcome.

Individualized optimal surgical, radiotherapeutic and medical treatment will be the aim for the future.

Besides this, prevention will also be a further step to overcome this disease.

Much progress has been made in screening, diagnosis, treatment and prevention of breast cancer over the past 40 years.

As a result, breast cancer is now a highly curable disease, if early detected and optimally treated. Breast cancer units and guidelines will further support this progress.

\section{IS047}

\section{Systembiologie zur Beantwortung biomedizinischer Fragen: Metastasen und Resistenzen bei Krebs}

\section{Arlt D., Sahin Z., Korf U., Löbke C., Fröhlich H., Sültmann H., Beißbarth T., Wiemann S., Poustka A.}

Deutsches Krebsforschungszentrum (DKFZ), Molekulare Genomanalyse, Heidelberg

Bei der Entartung von Zellen sind die Kontrollmechanismen zur Zellteilung und Integrität außer Kraft gesetzt, was zur Enstehung von Tumoren sowie zur Bildung von Metastasen führt. Insbesondere bei der Resistenzbildung gegen Therapeutika und bei der Metastasierung hat dieser Kontrollverlust fatale Folgen für die Krebs-Patienten. Die Fähigkeit von Krebszellen vom ursprünglichen Tumor weg zu wandern, ist eine der frühen Ereignisse bei der Metastasierung. Um Proteine zu identifizieren, die bei diesem Prozess eine Rolle spielen, haben wir eine genomweiten siRNA Screen durchgeführt, der den Effekt von Proteinen auf die Ablösung von Zellen misst. Aus den gefundenen Kandidatenproteinen wurde mittels verschiedener bioinformatischer Methoden ein Proteinnetzwerk ermittelt, welches die Interaktionen zwischen Tumorzellen und deren unmittelbarer Umgebung wesentlich beeinflusst. Dieses Netzwerk beinhaltet mehrere Proteine, deren Wirkungsmechanismus außerhalb der Zelle zum tragen kommt, was wiederum einen regulatorischen Einfluss auf verschiedene Signalwege haben kann. Für dieses System werden nun Experimente durchgeführt, die den Einfluss auf Zellwachstum, Zelltod, Signaltransduktion und Integrität messen. In einem weiteren Projekt untersuchen wir Bypass-Mechanismen, die bei der Resistenzbildung in der
Brustkrebs-Therapie eine Rolle spielen. Zunächst wurde ein Protein-Netzwerk basierend auf publizierten Daten und Ergebnissen aus Expressionsstudien generiert, dessen Proteine einen Einfluss auf die Zellzyklus Regulation in Brustepithelzellen haben. Mittels Simulation wurde dann ermittelt, welche Proteine in Kombination ausgeschaltet werden müssen, damit kein Bypass, der zur Resistenzbildung führen würde, mehr möglich ist. Anhand dieser Daten wurden gezielte Perturbationen mittels RNA Interferenz duchgeführt und die zeitaufgelöste Quantifizierung der Protein Abundanz und Aktivierung vorgenommen, um die Ergebnisse aus den Simulationsversuchen zu verifizieren. Das Ziel dieser systembiologischen Ansätze ist, verschiedene molekulare Informationen in Modellen zu kombinieren, um die biologischen Prozesse und deren Komplexität zu verstehen und schließlich Funktionen auf der zellulären Ebene vorherzusagen. Durch die verstärkte Einbindung klinischer Expertisen sollen zukünftig auch prospektive Studien ermöglicht werden.

\section{IS048}

Aims and struggle: How does the German cancer information service kid generate evidence- based information and how would it effectively communicate it to the public?

\section{Hagmann $R$}

Deutsches Krebsforschungszentrum, Krebsinformationsdienst, Heidelberg

The German Cancer Information Service KID aims to offer established and confirmed information about cancer based on the best available evidence. Providing evidence based information on cancer in Germany is complicated by the lack of publications with evidence level I, such as highly developed guidelines. In many fields there exists a variety of different opinions because of the absence of randomised controlled clinical trials and systematic reviews. People in the street demand new developments to be rapidly introduced into general medical care, thus putting high pressure on scientists. Sometimes they are not given enough time to thoroughly investigate and prove the efficacy of a new method by means of EBM.

Most people who call up the KID are patients or relatives. The main inquiries regard cancer diagnosis and treatment. People actually do not want to know exactly what the evidence of certain methods are, because they are mostly convinced that the efficacy of the procedures has already been proven scientifically . They would rather like to know whether the procedure they are offered is the best for themselves. Satisfactory answers are hardly to find in these cases, and it is a difficult task for the KID to explain the lack of evidence concerning a certain treatment method or to justify that there are different opinions on a medical method.

On the other hand we observe a growing public awareness about differences in the quality of medical care and rising interest in the process of EBM. Consequently, there is an increasing request for evidenced based information and for the sources of special information given by the cancer information service. Our aim in the future is that more patients ask their doctors whether the suggested treatment is based on reliable outcome data from clinical trials, or only on the doctor's individual opinion.

If we succeed to understandably communicate information about cancer to the public and enhance the understanding of evidence based medicine, we will be able to contribute to the improvement of cancer patient's care in our country.

\section{IS049}

\section{Therapiezieländerung: Kommunikative und ethische Herausforderungen}

\section{Schildmann J.}

Universitätsklinikum, Bochum

Entscheidungen über Therapiezieländerungen sind ein wichtiger Bestandteil der Arbeit in der Onkologie und anderen klinischen Fachgebieten. Empirische Untersuchungen belegen, dass diese Entscheidungen von vielen Ärzten als schwierige Herausforderung wahrgenommen werden. Die medizinisch-fachliche Expertise, ethische und kommunikative Kompetenzen sind notwendige 
Voraussetzungen, um den Entscheidungsfindungsprozess professionell gestalten zu können. In diesem Beitrag aus der klinischen Medizinethik werden die für eine angemessene Entscheidungsfindung notwendigen ethischen und kommunikativen Kompetenzen beschrieben und mit Blick auf die Anwendung in der klinischen Praxis diskutiert. Den Ausgangspunkt bilden eine Definition des Terminus „Therapiezieländerung “ und die Beschreibung typischer Szenarien im Fachgebiet der Hämatologie-Onkologie, in denen entsprechende Entscheidungen getroffen werden. In einem zweiten Schritt erfolgt eine Analyse des Begriffs der „medizinischen“ beziehungsweise ,ärztlichen Indikation“ als wichtige Grundlage für Entscheidungen über Therapiezieländerungen. Mit Blick auf die Bedeutung normativer Urteile im Zusammenhang mit diesen Entscheidungen werden anschließend Modelle und Methoden der ethischen Reflexion und Analyse vorgestellt. Im abschließenden Teil des Beitrags wird die Bedeutung kommunikativer Kompetenzen mit Blick auf die an der Entscheidungsfindung beteiligten Mitglieder des Behandlungsteams sowie im Hinblick auf das Gespräch mit Patienten sowie dessen Nächsten analysiert.

IS050

\section{UV-schutz}

\section{Berneburg M.}

Eberhard Karls Universität, Universitäts-Hautklinik, Tübingen

Die Haut des Menschen schützt vor einer Vielzahl schädigender Umwelteinflüsse. Wegen der akuten und chronischen Folgen wie Sonnenbrand einerseits sowie Lichtalterung und Hautkrebs andererseits ist ultraviolette (UV) Strahlung der Sonne eine der gefährlichsten Noxen, vor der unsere Haut geschützt werden muss. Schutz vor herkömmlichem Sonnenbrand durch UVBFilter stellt heutzutage eine Selbstverständlichkeit dar. Die Entwicklung und Anwendung von effektiven und sicheren Substanzen mit Schutz im UVABereich ist dagegen erst in jüngerer Zeit erfolgt. Insbesondere die Folgen chronischer UV-Exposition stellen eine besondere Gefahr dar. Hierzu gehört die Entstehung von Hautkrebs und vorzeitige Alterung der Haut durch UVStrahlung. Untersuchungen in Mäusen und an Patienten mit erhöhtem Hautkrebsrisiko haben ergeben, dass hier UVB-Strahlung aber auch die UVAStrahlung eine wichtige Rolle spielt. Etabliertes und neues Wissen zu diesem Thema wird im Rahmen des Vortrages besprochen. Über die wissenschaftlichen Grundlagen hinaus werden auch die praktischen Hinweise für das Verhalten im Zusammenhang mit Lichtschutz vorgestellt. Intensive Sonneneinstrahlung, in der Zeit zwischen 11:00 und 15:00 Uhr, sollte gemieden werden. Sonnenschutzpräparate sollten vor dem Sonnen aufgetragen werden und danach mehrmals während der Sonnenexposition. Babys und Kleinkinder sollten allgemein und durch schützende Kopfbedeckung und Kleidung vor direkter Sonneneinstrahlung geschützt werden. Insgesamt ist zu raten Präparate mit hohem Lichtschutzfaktor sowohl gegen UVB als auch gegen UVA anzuwenden.

\section{IS051}

\section{Factors indicating need for rehabilitation and defining the outcome after multi-modal therapy of breast cancer}

\section{Schröck R.}

Paracelsusklinik Scheidegg, Gynäkologische Onkologie, Scheidegg

Functional deficiencies resulting from typical symptoms or from multi-modal therapy of primary or recurrent breast cancer often necessitate rehabilitation programs.

Typical somatic factors are painful malfunction of shoulder, arm or lymphatic system, sexual problems, fatigue, or sleeping disorders. Typical psychological factors are anxiety of recurrence, reduced self-confidence, and depression. Subjective lack of information is reported about side effects of endocrine therapy, stress reduction, possible support in social and economic problems, potential advantages of dietetic and physical training, and occupational support.

If the status of a patient is suitable for rehabilitation, she must be informed about the possibilities and her legal right for rehabilitation in a specialized rehab hospital. In cooperation with the patient a suitable therapy plan will be aimed at therapy-goals, based on specific oncologic and rehabilitative procedures and includes medical function-related therapy as well as psychooncological, occupational, and educational programs. For the German pension insurance company an expert socio-medical evaluation of the patient must be based on the current functional level and not the oncological prognosis, whereas the current degree of impairment determines the legal disability. External and internal quality management is integrated into the oncologic rehabilitation system: At the beginning and at the end of a three weeks rehabilitation program in a specialized oncologic rehab hospital the described somatic and psychological factors are assessed. Measurements of physical strength, improvement of pain and anxiety reduction, satisfaction with therapy and outcome are used in an individual goal attainment system. From this data, a quality score is calculated every three months and reported regularly to the therapeutic team. Additionally, a bench marking with similarly specialized hospitals is performed and once a year data about the outcome regarding the patients "returning to work" are obtained.

All data indicate that the evaluation of the described typical factors for need of oncologic rehabilitation result in more specific rehab programs and high satisfaction of the patients in regard to their individual therapy goals.

\section{IS052}

\section{Small-molecule inhibitors of cancer-relevant protein- protein interactions}

\section{Kiessling A., Schust J., Müller J., Sperl B., Reindl W., Hollis A.,} Berg $T$.

Max-Planck-Institut für Biochemie, Abteilung für Molekularbiologie, Martinsried

Signals originating at the cell surface are conveyed by a complex system of interconnected signaling pathways to the nucleus. They converge at transcription factors, which in turn regulate the transcription of sets of genes which ultimately determine the cellular phenotype. Therefore, cell-permeable inhibitors of transcription factors would offer new opportunities to directly interfere with gene transcription. However, transcription factors are usually considered to be "nondruggable". Therefore, we aimed to explore the feasibility of inhibiting dimeric transcription factors by small organic inhibitors of protein-protein interactions. As one of our model systems, we have chosen the oncogenic transcription factor c-Myc. Since all known biological functions of c-Myc depend on its interaction with Max, inhibition of the c-Myc/Max interaction represents the most direct approach towards inhibition of c-Myc. We have identified three pyrazolo[1,5- $a$ ]pyrimidines as the first small molecules which inhibit both dimerization and DNA binding of c-Myc with preference over related transcription factors in vitro. Furthermore, we have identified a substitution pattern which appears to be associated with activity of pyrazolo[1,5- $a$ ]pyrimidines against cMyc/Max dimerization. Our inhibitors specifically exhibit c-Myc-dependent proliferation, transcription, and oncogenic transformation.

Another group of model systems includes Signal Transducers and Activators of Transcription (STATs), a family of latent cytoplasmic transcription factors that transmit signals from the cell membrane to the nucleus. Since the SH2 domain of STATs is required for both their tyrosine-phosphorylation and dimerization, the most logical approach toward inhibition of any STAT would impair the function of its SH2 domain. We have identified Stattic, the first nonpeptidic small molecule shown to selectively inhibit the function of the STAT3 $\mathrm{SH} 2$ domain regardless of the STAT3 activation state in vitro. Stattic selectively inhibits activation, dimerization, and nuclear translocation of STAT3 and increases the apoptotic rate of STAT3-dependent breast cancer cell lines. Furthermore, we have identified small-molecule inhibitors of the STAT5 SH2 domains, which selectively prevent activation of STAT5 in lymphoma cells.

\section{IS053}

\section{Therapie und Ergebnisse bei Kindern, Jugendlichen und jungen Erwachsenen mit AML}

\section{Creutzig U. ${ }^{1}$, Schlenk R.F. ${ }^{2}$, Büchner T. ${ }^{1}$}

${ }^{1}$ Universitätsklinikum, Münster; ${ }^{2}$ Universität, Innere III, UIm

Die Bedeutung der Einflussgröße „Alter“ wurde bei unter 30-jährigen AMLPatienten bisher kaum untersucht. Wir haben eine gemeinsame Auswertung durchgeführt mit 891 Patienten unter 18 Jahren aus den pädiatrischen AMLBMF-Studien 93/98 und 290 Jugendlichen und jungen Erwachsenen zwischen 16 und 30 Jahren, die in den Studien AMLCG 92/99 und AMLSG HD 93/98A behandelt wurden. Behandlungspläne und Dosisintensität der Studien waren vergleichbar. 
Ergebnisse: Die Initialbefunde und Risikofaktoren unterschieden sich insbesondere zwischen den sehr jungen Kindern (unter zwei Jahre) und den anderen Altersgruppen, doch nur gering zwischen Kindern (zwei bis 13 Jahre), Jugendlichen (13 bis 21 Jahre) und jungen Erwachsenen (21 bis 30 Jahre). Die Behandlungsergebnisse waren insbesondere bei Kindern sehr gut (5-jähriges ereignisfreies Überleben [EFS]: $54 \% \pm 3 \%$ ); sie lagen geringfügig niedriger bei Jugendlichen $(46 \% \pm 4 \%, \mathrm{p}=0.03)$ und waren ungünstig bei jungen Erwachsenen $(28 \% \pm 5 \%, \mathrm{p}=0,001)$.

Auch bei Beachtung der Risikogruppen - definiert nach zytogenetischen Subgruppen - zeigte sich die gleiche Abstufung wie bei der Gesamtgruppe. Auffällig war, dass mit zunehmendem Alter auch die Anzahl der Patienten mit einem Blastenanteil von über $5 \%$ im Knochenmark nach Induktion zunahm. Gleichzeitig verschlechterte sich mit steigendem Alter die Prognose insbesondere bei Patienten mit erhöhtem Blastenanteil. Insgesamt zeigen unsere Untersuchungen, dass die biologischen Daten vorwiegend zwischen Kleinkindern unter zwei Jahren und den älteren Altersgruppen unterschiedlich waren. Beim Vergleich von gleichen Altersgruppen, die in unterschiedlichen Studien behandelt wurden, ergaben sich nur minimale Unterschiede in der Prognose. Dies steht im Gegensatz zu Ergebnissen, die bei der akuten lymphoblastischen Leukämie berichtet wurden. Andererseits sank die Prognose nach dem Kindesalter unabhängig von anderen Risikofaktoren. Das bedeutet, dass nicht nur bei älteren Erwachsenen der Faktor „Alter“ als ein zusätzlich ungünstiger Faktor anzusehen ist.

IS054

\section{Kompass - Communication competence to improve patient-physician interaction by structured communication skills training}

\section{Keller M., Schulmeister E., Brennfleck B.}

Universitätsklinik, Psychosomatische Medizin, Psychoonkologie, Heidelberg

The patient-physician interaction assumes great significance for cancer patients and represents a central component of the oncology care delivery process. However, this faces physicians' own substantial strain and their so far insufficient education and training concerning this matter. Target of the project is to develop a structured and standardized communication training to improve psychosocial competence of oncologists as well as to reduce their professional distress and to evaluate the training effects. During the first project phase two training workshops will take place at each of the cooperating centres (8-10 participants, 2 experienced trainers, minimum 20 hours in 2 days, use of 'patientactors'). Afterwards the training program will be modified by the task force according to the respective experiences. During the first project phase the change of communication skills will be assessed in a prospective/ controlled pre-post design. Self-assessment of the participating oncologists will be collected before, directly following and 6 months after the KoMPASS training and it will be compared with the assessment of the control group (physicians without training). Possible interaction effects of motivation or willingness for attending communication training will be controlled. Internationally known instruments will be used to assess self-efficacy (relating to various communicative requirements), occupational distress and burn-out symptoms. In the second phase of the project three KoMPASS trainings will be conducted at each centre, supplemented by a refresher-course after 6 months. The evaluation will be done with a one-group pre-post design by using expert rating of the communicative behaviour ("skills" and "attitude") and the change after the training based on a standardized rating-system [Modified Roter Interaction Analysis System - RIAS] of video-documented patient-physician interaction, recorded respectively before and 6 months after the training. The target sample size comprises 160-200 oncologists. All KoMPASS trainings will be evaluated with regard to participants' satisfaction and personal benefit (quality control).

\section{IS055}

\section{Hope - A success story}

Lindena $G$.

CLARA Klinische Forschung, Kleinmachnow

In 200767 palliative care inpatient units, 8 oncological units, 24 inpatient hospices, outpatient services of 28 physicians and 22 nursing care services documented 3184 patient courses following the quality management and benchmarking system HOPE HOspice and Palliative care Evaluation. The number of ambulatory services of medical and nurse care is still increasing since their first inclusion in 2004 , but is not regionally covering, while the participating palliative care units represent $75 \%$ of the available beds in Germany. Since 1999 agreed criteria (patient diagnoses, symptoms and severity of disease, drug and non-drug interventions as well as aims, results, end of respective care and in case of change the specific description) were documented for 30 consecutive patients during a yearly documentation period of 3 months, then evaluated and reported by comparing unit specific data with the data of the attending groups of institutions. Additional data sheets were developed for research on scientific questions or quality of care. Thus specific contributions of different services were evaluated - still quality of nursing care is not evaluated but severity of disease and amount of nursing instead - and their descriptive questions added to the combined sheet of all medical, nursing, psychological and social services in one institution.

Quality management in palliative care should use specific instruments for the specific tasks in the different settings for all aspects of medical and psychological symptom control, nursing and social issues as well as communication with patients and their families. The base sheet of HOPE is recommended for standard documentation purposes in palliative care by the Society for Palliative Care in Germany and the German Hospice and Palliative Care Association and additionally supported by the German Cancer Society. The yearly quality cycle, the documentation period of up to three months, the documentation preparing and results discussion meetings lead to the success of HOPE. It is now necessary to keep on with the actual documentation tasks in the development of ambulatory care, in integrating concepts and structures in the growing palliative care services in Germany.

Due to a continuing independent grant from Mundipharma $\mathrm{GmbH}$ and additional sponsoring by the named associations documents, online availability of the data, reports and meetings were free for the attending institutions.

\section{IS056}

\section{Decision criteria for the use of artificial nutrition at the end of life}

\section{Schuler U. ${ }^{1}$, Gretzinger $S .{ }^{1}$, Schubert B. ${ }^{2}$}

${ }^{1}$ Medizinische Klinik I, Dresden; ${ }^{2} \mathrm{KH}$ St.Joseph-Stift, Palliativstation, Dresden

Energy metabolism is the most elementary characteristic of life and precedes any other physiologic process in evolutionary history. It is not surprising, that "eating" in the human perception is not reduced to "intake of calories, vitamins etc." but has profound archetypical, sometimes subconscious connotations. Rules and rites concerning food play an essential role in religion (offering to the gods/ancestors, fasting, holy grail, communion etc. ) and the sharing of food is fundamental to the creation of human relations, ranging from breastfeeding to the original meaning of "symposion" as a party with drinking and eating. Both is reflected in proverbial expressions like "eating keeps body and soul together" and "love goes through the stomach". Therefore nutrition has implications beyond energy metabolism and sensory satisfaction into psychosocial and maybe even spiritual dimensions. It is not surprising, that communication and decisions about nutrition go way beyond the immediate rationale (duration of survival, influence on symptoms) by which the physicians mind is preoccupied. Cessation of nutrition may be understood as leaving the human community (defined by eating together) and more than any other limitations imposed by disease as an omen of death.

In the physiological medical context it is well established that parenteral nutrition $(\mathrm{PN})$ or artifical enteral nutrition (EN) can contribute to prognosis and well-being in situations of disturbed intake or absorption either due to obstructing tumors of the upper GI-tract, reduced GI absorption area or side effects of radio-/chemotherapy. This is especially true, if no other disease manifestations limits prognosis within few weeks or months. On the other hand, there is evidence, that the etiology of extreme tumor cachexia is determined by genetic factors and mediated by cytokines, which are beyond the reach of merely nutritional interventions. In the presence of lung pathology, ascites or venous or lymphoid flow obstruction, the fluid intake of PN may become a burden and requires appropriate restrictions. When approaching death (within days or few weeks), the impact of nutrition on prognosis is overrated, but this "rational" approach does not account for the cultural factors described above. All these have to be balanced against the risks, taking into account that the 
continuation of PN or EN via PEG is a different issue than the interventions of creating longterm venous access or a PEG.

\section{IS057 \\ Developing a postgraduate course of palliative care in Germany}

\section{Schubert B. ${ }^{1}$, Schuler U. ${ }^{2}$}

${ }^{1} \mathrm{KH}$ St.Joseph-Stift, Palliativstation, Dresden; ${ }^{2}$ Medizinische Klinik I, Dresden

Postgraduate education in palliative care in Germany has been limited to the clinical training in established PCUs and the training course system based on the curriculum developed by the German Society for Palliative Care (DGP) leading to the board certified degree "Zusatzweiterbildung Palliativmedizin". Courses with a focus on the scientific basis of palliative care leading to a Masters Degree have been available abroad for some years, but not in Germany. An initiative of the Dresden International University has led to the development of a curriculum for a multidisciplinary two-year course which can be completed while working full time. Introductory modules focus on scientific methodology, communication and ethical and legal aspects of end of life decisions. Later modules include (among other subjects) symptom control, medical infrastructure, legal issues, medical didactics and multiprofessional and transcultural aspects of palliative care. One focus is the analysis how art (literature, visual arts and music) deals with pain, suffering and death. A brief introduction into the ongoing curriculum and the aims of the course will be given. After successful completion of the course and a Masters Thesis, participants will receive the academic degree of ,Master of Science in Palliative Care“(M. Sc.)

\section{IS058}

\section{Treatment of elderly patients with colorectal cancer - Therapie des älteren patienten mit kolorektalem karzinom}

\section{Honecker F.}

Universitätsklinikum Hamburg-Eppendorf, Onkologisches Zentrum, Hamburg

Colorectal cancer is a disease mainly affecting the elderly. $70 \%$ of patients are $>65$ years of age. As elderly patients often present with impaired reserves due to e.g. reduced performance status, increased comorbidity, or low social support, a thorough assessment of the patient's fitness for therapy should be performed before a decision is taken. A geriatric assessment can help to identify unfit or frail patients who are more likely to suffer from adverse outcomes and may not benefit from chemotherapy. Both in the adjuvant and in the palliative setting, there is enough data to support the use of 5-fluorouracil (5-FU) based chemotherapy, alone or in combination, in fit elderly patients. Systemic chemotherapy has shown to effectively reduce mortality in the adjuvant situation and has proven clinical benefit in terms of longer survival, control of symptoms and quality of life in patients that cannot be cured. Within the last years, combinations of 5-FU and new substances such as oxaliplatin and irinotecan have been examined within clinical trials. The results indicate that selected elderly patients may derive benefit from palliative treatment that is comparable to that observed in younger patients, albeit at the cost of increased gastrointestinal toxicity. Prospective data from trials including less fit or even frail patients, however, is still scarce. Recently, results from a large randomized controlled trial including 460 patients with unpretreated metastatic colorectal cancer judged unfit for full-dose combination chemotherapy have been reported (Seymour et al, ASCO 2007). In this frail elderly population, substituting capecitabine for FU avoided the need for venous port systems, but did not improve overall QL or efficacy, and increased toxicity. Addition of oxaliplatin gave significantly higher anticancer activity in terms of response rate without increasing toxicity, but at the cost of slightly reduced quality of life. Clearly, further clinical trials, designed specifically for this population, are necessary, as is the incorporation of some kind of geriatric assessment in order to improve care of elderly patients with colorectal cancer in the future.

\section{IS059 \\ Complementary substances: Vitamins and trace elements - What is really evidence based?}

\section{Micke O.}

Franziskus Hospital, Klinik für Strahlentherapie und Radioonkologie, Bielefeld

The use of complementary or alternative medicine is the norm for many cancer patients. One of the major interests of these patients is vitamins and trace elements. An own study on 1013 cancer patients showed that $18 \%$ use any kind of vitamins or vitamin combinations and $17 \%$ trace elements or combinations, more than half of these patients use the essential trace element selenium.

Despite this interest the level of evidence on vitamins and trace elements is low and the number of randomized trials and meta-analyses is very limited. Most data are available on cancer prevention by vitamins or trace elements based on their antioxidative features: A chochrane analysis of antioxidant supplements for preventing gastrointestinal cancers showed, that based on properly designed and conducted randomised clinical trials, convincing evidence that beta-carotene, vitamin $\mathrm{A}$, vitamin $\mathrm{C}$, and vitamin $\mathrm{E}$ or their combinations may prevent gastrointestinal cancers is not found. These antioxidant supplements may even increase mortality. Selenium alone may have preventive effects on cancer. This finding, however, is based on trials with flaws in their design and needs confirmation in properly conducted randomised clinical trials.

Another chochrane analysis on drugs for preventing lung cancer in healthy people revealed that there is currently no evidence to recommend vitamins such as alpha-tocopherol, beta-carotene or retinol, alone or in combination, to prevent lung cancer. A harmful effect was found for beta-carotene with retinol at pharmacological doses in people with risk factors for lung cancer.

There are only few data on cytoprotective effects of vitamins and trace elements in chemotherapy and radiotherapy: A chochrane analysis on Selenium for alleviating the side effects of chemotherapy, radiotherapy and surgery in cancer patients showed There is insufficient evidence at present that selenium supplementation alleviates the side effects of tumour specific chemotherapy or radiotherapy treatments. Or, that it improves the after effects of surgery, or improves quality of life in cancer patients or reduces secondary lymphedema. To date research findings do not provide a basis for any recommendation in favour or against selenium supplementation in cancer patients.

A small randomized trial presented a beneficial effect of zinc sulfate is in decreasing the severity of radiation-induced mucositis and oral discomfort. An own randomized phase III study in 82 patients undergoing pelvic irradiation for gynaecological malignancies showed a significant reduction of radiogenic diarrhoea by application of sodium selenite.

In conclusion, despite the lack of clear evidence vitamins and trace elements remain a very interesting topic for further research and discussion in oncology.

\section{IS060}

\section{Custom-made reconstructive surgery in the head and neck region - An overview}

\section{Schwenzer-Zimmerer K}

Universitätsspital, Kiefer-und Gesichtschirurgie, Basel

Introduction: Individual 3-D shaped facial reconstructions will be presented. Different procedures are possible. In patients with reasons against a reconstruction with an autogenous transplant, a individualized prosthesis can be produced, in other cases soft tissue, bony and dental reconstructions are chosen in order to rehabilitate patients completely functionally and esthetically. The tumor defects can be filled with microvascular reanastomosed soft and hard tissue transplants.

Material and Methods: Individualized 3-D planned and computer assisted reconstructions of all levels of the face including the skull base after tumor resections were accomplished:

MRI, CT and functional data sets were used to create multimodal 3-D virtual models of the patients head and neck region. The segmentation and visualization techniques used were bases on the principle of fusing various data sets. Through segmentation and registration steps, the complementary case relevant information was extracted and integrated in the virtual 3-D planning. A reconstructive computer-aided method based on patient-individual virtual 3-D models to plan exactly the preformed graft respecting the dental and bony situation at the host site as well as the anatomy of the graft site and the transfer of the 
virtual plan into the operation theater is shown. The multidisciplinary approach for extended reconstructive skull base surgery using navigation will be presented. Furthermore the reconstruction of hard and soft palate defects using functional reanimated forearm flaps is shown.

Results and Discussion: Precise planning can help to reduce operation time. It allows the surgeon to define the optimal surgical approach for complex reconstructions. In order to achieve the best results, different configurations can be tried in order to create the best matching shape of the graft in respect of the bony and dental situation at the host site. The final plan can be realized in the operation theater using a stereolithographic drill guide which summarizes all spatial information derived from the preoperative plan or by navigation due to the individual case.

\section{IS061}

\section{Complementary therapies: Homeopathy}

\section{Rostock M.}

Klinik für Tumorbiologie an der Albert-Ludwigs-Universität, Freiburg

Many cancer patients use homeopathic remedies with the aim to improve their quality of life and to treat cancer therapy related or illness related complaints. Many patients additionally hope that this kind of complementary treatment also has a positive effect on the course of their illness.

Up to now there are only five randomized placebo-controlled trials investigating homeopathic treatment in cancer patients. Two RCTs prooved the efficacy of homeopathic remedies in prevention and treatment of side effects of radiotherapy. In the RCT from Kulkarni, 1988 with patients with different types of cancer $(n=82)$ the radiation reaction index was lower in the intervention groups, but differences were not significant. Balzarini (2000) tested two homeopathic remedies vs. placebo in breast cancer patients undergoing radiotherapy $(\mathrm{n}=61)$. The homeopathic treated patients showed a significant decrease of total severity score of symptoms, but only during recovery.

Two placebo-controlled RCTs studied menopausal symptoms in breast cancer survivors (Jacobs J, 2005, Thompson EA, 2005). None of these studies came to significant improvement of hot flashes under homeopathic treatment, while in a previous prospective observational study the homeopathic approach appeared to be clinically useful in the management of oestrogen withdrawal symptoms in breast cancer patients (Thompson EA, 2003).

Another placebo-controlled RCT with a homeopathic combination remedy for prevention and treatment of chemotherapy-induced stomatitis showed significantly reduced severity and duration of stomatitis in the intervention group (Oberbaum M, 2001).

While most observational studies on homeopathy in general medicine show beneficial effects, the few randomized placebo-controlled trials in cancer patients have conflicting results. The great demand for homeopathic treatment in cancer patients calls for further research.

\section{IS062}

\section{Radiotherapeutic strategies in oncological emergency}

\section{Adamietz $l$.}

Ruhr-Universität-Bochum, Strahlentherapie, Herne

Oncological emergency can be defined as an acute condition that is caused by cancer or its treatment, requiring rapid intervention to avoid death or severe permanent damage. Radiotherapy is beneficial in structural or obstructive emergencies caused by a space-occupying tumor as superior vena cava syndrome, spinal cord compression, increased intracranial pressure, hemorrhage and airway obstruction

Superior vena cava syndrome (SVCS) results from the partial or complete obstruction of blood flow through the superior cava vein to the right atrium, causing severe reduction in venous return from the head, neck and upper extremities. The management of SVCS has shifted from empirical radiation, recommended for more than two decades, to a more methodical diagnostic evaluation. The only accepted exception to this may be those cases with impending airway obstruction or severe increase in intracranial pressure. Radiotherapy remains the main option for patients having SVCS due to tumors insensitive to chemotherapy, such as recurrent disease of non-small-cell lung cancer. If a new patient with a non-small-cell lung cancer presents with SVCS, initial treatment may be chemotherapy. But if there is no objective response, radiotherapy should be given promptly. External beam radiation for SVCS is well tolerated and an improvement of symptoms is seen within a few weeks. Spinal cord compression is the first manifestation of cancer in $10 \%$ of patients who present with this complication and will also occur during the disease course of $5-10 \%$ of all cancer patients. It should be considered a true oncological emergency. Delays in starting treatment may result in irreversible consequences, including paraplegia. For most patients with spinal cord compression and a radiosensitive tumor, radiation therapy with dexamethasone is considered the standard treatment. In some cases, surgical decompression plus other techniques to stabilize the spine may also help.

Increased intracranial pressure may be caused by brain metastases. Around a quarter of cancer patients will die with intracranial metastases. Lung, breast and melanoma are the most common tumors that metastasize to the brain. If multiple nodules are seen, whole-brain irradiation is considered standard. However, for a single brain metastasis, surgery plus radiation should be considered. Radiosurgery may be indicated in patients having fewer than three metastases, each measuring $<2 \mathrm{~cm}$.

Massive hemorrhage may be inhibited by radiotherapy causing vascular thrombosis and necrosis of contributing vessels. External radiation or brachytherapy given together with steroids may also be useful in opening an acute obstructed airway.

\section{IS063}

\section{Supportive-expressive group therapy for cancer patients - Feasability and evaluation in outpatient care}

Reuter K.

Universitätsklinik , Abt. Psychiatrie und Psychotherapie, Freiburg

Purpose: Due to the growing need for short term, cancer specific, group interventions, this study aimed to investigate brief supportive-expressive group therapy (Classen et al., 1993) for three different types of cancer (breast and colon cancer as well as malignant melanoma) and to test the feasability of this therapy module in the German health care setting.

Methods: The uncontrolled pre-post design included eight intervention groups with 12 weekly sessions. Participants were recruited in Interdisciplinary Breast Cancer Treatment Centers the department of dermatology of the University Medical Center, Freiburg and Gastrointestinal Cancer Centers. Participants ( $\mathrm{N}=48 ; 78 \%$ female : $22 \%$ male) completed self report questionnaires measuring quality of life and fatigue, mood disturbances, and coping as well as social support. After intervention, patient satisfaction and group experiences during therapy were assessed with self rating inventories. Results: Acceptance of the intervention was good with a drop out rate of $20 \%$ and an average rate of 2 missed sessions per patient. Although not statistically significant, patients quality of life, in particular emotional well-being, fatigue and body image, improved from pre to post intervention in all cancer groups. Satisfaction with treatment was highest in patients coping with their illness by actively seeking information and experiencing positive social support. The most important therapeutic experiences in the patient groups were expressing true feelings and belonging to a group.

Conclusion: Brief supportive-expressive group therapy can be adapted to different groups of cancer patients and implemented in oncological outpatient settings in Germany. Randomized studies are needed to examine treatment effects in controlled conditions.

\section{IS064}

\section{ZNS-Lymphome}

Thiel E.

Charité, Berlin

Das primäre Lymphom des zentralen Nervensystems (PZNSL) ist definiert als ein Lymphom, das zum Zeitpunkt der Erstdiagnose auf das ZNS begrenzt ist. Aus ungeklärtem Gründ nimmt die Inzidenz des PZNSL auch bei immunkompetenten Patienten zu. Die Prognose des PZNSL ist immer noch relativ ungünstig. Das Alter und der Allgemeinzustand des Patienten sind die wichtigsten Prognosefaktoren. Aufgrund der Seltenheit der Erkrankung konnte die optimale Primärtherapie des PZNSL bisher nicht etabliert werden. Die Ganzhirnbestrahlung hat zwar die Vorteile einer hohen Ansprechrate und einer 
relativ geringen Toxizität, allerdings bietet sie in den meisten Fällen keine Langzeitkontrolle und sollte daher nicht mehr als Therapie erster Wahl eingesetzt werden. Durch die Kombination von Chemotherapie mit Hochdosis Methotrexat (HDMTX) und Schädelbestrahlung kann zwar eine deutliche Verlängerung der Überlebenszeit im Vergleich zur Strahlentherapie allein erreicht werden, allerdings um den Preis höherer Spätneurotoxizität vor allem bei Patienten $>60$ Jahre. Die Chemotherapie allein wurde bisher unzureichend prospektiv evaluiert; ihre Gleichwertigkeit mit dem kombinierten Verfahren gilt daher noch nicht als belegt. Die Rolle der konsolidierenden Schädelbestrahlung nach einer auf HDMTX-basierender Chemotherapie wird zu Zeit in einer randomisierten multizentrischen deutschen Studie (G-PCNSL-SG1) geprüft.

Die Prognose von Patienten mit sekundärem ZNS-Befall eines aggressiven Lymphoms ist unter der konventionellen Therapie mit intrathekaler Zytostatikagabe und Neuroachsenbestrahlung noch ungünstiger mit einer medianen Überlebenszeit von maximal 6 Monaten. In einer Phase II Studie wird aktuell der Stellenwert einer liquorgängigen systemischen Chemotherapie gefolgt von Hochdosischemotherapie mit autologer Stammzelltransplantation geprüft.

\section{IS065}

\section{Moleculargenetic changes in myelodysplastic syndrome}

\section{Hofmann W.-K}

Campus Benjamin Franklin, Berlin

Myelodysplastic syndromes are clonal disorders of the hematopoietic stem cell characterized by peripheral cytopenias in combination with a hyperplastic bone marrow. The classification according to the WHO includes mainly morphological criteria and is supplemented by the International Prognostic Scoring System which takes cytogenetical changes into consideration when determining the prognosis of MDS. The underlying mechanisms causing primary MDS requires further work. Different molecular alterations which have been described, suggest that it is a multistep alteration to the hematopoietic stem cells that include genes involved in cell cycle control, mitotic checkpoints as well as growth factor receptors. Secondary signal proteins and transcription factors which gives the cell a growth advantage over its normal counterpart, may be affected as well. The accumulation of such defects may finally cause the leukemic transformation of MDS. However, the identification of single or combined molecular defects (e. g. the recent described gene alteration of the RPS14 gene in bone marrow CD34+ cells collected from patients with MDS, in particular the 5q- syndrome) may contribute to the further selection of active targetspecific drugs in myelodysplastic syndrome.

\section{IS066}

\section{Therapeutic approaches in tumour therapy related fatigue}

Feyer $P$.

Vivantes Klinikum Berlin Neukölln, Berlin

Fatigue is one of the most complaints of patients with cancer. Fatigue exists in $50-96 \%$ of cancer patients particularly in individuals actively undergoing treatment.

Fatigue is difficult to describe and patients express it in a variety of ways. Generally fatigue may be defined as a condition characterized by distress and decreased functional physical and mental status related to a decrease in energy. Although a variety of treatment- and disease- related factors may contribute to the development of fatigue. The biochemical, physiologic, psychologic, and behavioural mechanisms of this symptom complex are poorly understood. Several instruments to measure fatigue have been validated in patients with cancer and are being utilized to characterize the symptom of fatigue and its effect on quality of life.

To quantify the fatigue in routine oncological praxis patients involved in the Patients Satisfaction and Quality in Oncological Care (PASQOC $)^{\circledR}$ Study 2004 were examined for their fatigue experience.

5600 patients from 49 oncological ambulatories were asked by means of a validated PASQOC-questionairy about the quality of oncological care in Germany. $60 \%$ of the patients suffered from fatigue. To define risk factors the severity of fatigue was correlated with demographic, therapeutic and tumor related factors, that were documented.

Risk factors were gender, age, social status, tumour diagnosis, chemotherapy and numereous therapy related side effects.
Consequently, a thorough understanding of fatigue may lead to initiation of effective interventions.

Interventions such as the use of erythropoietin to improve quality of life and functional capacity are being evaluated with promising results in numerous trials.

Evidence suggests that anaemia may be a major factor in cancer related fatigue and reduced quality of life in cancer patients. Anaemia can be related to the disease itself or due to therapy. The impact of anaemia varies depending on factors such as the rapidity of onset, patient age, plasma volume status, and the number and severity of comorbidities.

The European Cancer Anaemia Survey (ECAS) included 15367 patients demonstrated a prevalence of anaemia in 39\% at enrollment and 67\% during the survey. Anaemia prevalence and incidence in cancer patients are high. Anaemia correlates with poor performace status.

Cancer associated anaemia decreases patients'quality of life and may affect clinical treatment.

Anaemia is best managed by treatment of the underlying cause. Supportive treatment includes nutritional interventions, transfusions as well as Erythropoiesis - Stimulating - Agents in the treatment of anaemia.Treatment of anaemia with the objective of improvement of the quality of life should be one part of the complex treatment modalities of the fatigue syndrom. Furthermore general strategies, non - pharmacological and pharmacological treatment options taking into consideration the actualized guidelines should be proved for the individual patient.

\section{IS067}

\section{Palliative radiotherapy in breast cancer}

\section{Feyer $P^{3}$, Souchon $R .{ }^{1}$, Sauer $R^{2}{ }^{2}$, Sautter-Bihl M.-L. ${ }^{4}$,} Budach $W^{5}{ }^{5}$, Harms $W .{ }^{6}$, Dunst J. ${ }^{7}$, Wenz F. ${ }^{8}$, Haase $W^{9}$

${ }^{1}$ Allgemeines Krankenhaus Hagen $\mathrm{gGmbH}$, Strahlenklinik, Hagen; ${ }^{2}$ Universität Erlangen, Klinik für Strahlentherapie, Erlangen; ${ }^{3}$ Vivantes Klinikum Neukölln, Klinik für Radioonkologie, Berlin; ${ }^{4}$ Städt. Klinikum Karlsruhe, Klinik für Strahlentherapie, Karlsruhe; ${ }^{5}$ Universitätsklinikum, Klinik für Strahlentherapie, Düsseldorf; ${ }^{6}$ Universität Heidelberg, Klinik für Radio-Onkologie, Heidelberg; ${ }^{7}$ Universitätsklinikum Campus Lübeck, Klinik für Strahlentherapie, Lübeck; ${ }^{8}$ Universitätsklinikum Mannheim, Klinik für Strahlentherapie und Radioonkologie, Mannheim; ${ }^{9}$ ehemals: St. Vincentius-Kliniken, Klinik für Radioonkologie, Karlsruhe

Radiotherapy is an important tool in the palliative setting for breast cancer patients.

Improvement of the quality of life and minimizing of tumour induced symptoms are focused. Radiotherapy is an effective method to achieve a good symptom control in a short time without severe side effects.

Major indications for a palliative radiotherapy in metastatic breast cancer are painful bone metastases, brain metastases with and without neurological symptoms, spinal cord compression, meningeosis carcinomatosa and exulcerations of locally advanced or relapsed breast cancer.

In dependence of the prognosis and the performance status of the patient fractionation of the radiotherapy can range from a short treatment protocol as a single dose irradiation f.e. irradiation of painful bone metastases with $1 \times 8 \mathrm{~Gy}$ or radiosurgery for brain metastases up to treatment protocols over a period of one to four weeks.

The effectiveness on symptom control of a short course radiotherapy with higher single doses is equally to a conventionally fractionated radiotherapy . Important for the decision making are the prognosis and the performance status of the patient. Is the expected survival rate less than 6 months the possible increased late toxicity connected with high single doses is not of importance. In every case a careful discussion is necessary to chose the optimal individual treatment protocol for the patient.

Pain mainly caused by bone metastases or nerval infiltration can be improved by radiotherapy in $60-70 \%$ of patients during 1-2 weeks and the analgetics can be reduced. The effect is long lasting in $60 \%$ of patients and in general a second course of radiotherapy is possible, if it is necessary.

In brain metastases radiotherapy is an highly effective palliative treatment option. The neurological symptoms can be improved in $70-85 \%$ of the patients. The results are even better if there is an improvement of the neurological symptoms during the initial corticosteroid therapy. Whole brain irradiation, fractionated stereotactic radiotherapy or radiosurgery are used. 
The metastatic spinal cord compression is an emergency indication. In dependence of the neurological status before starting the radiotherapy there can be achieved a remission in $30 \%$ up to $80 \%$.

Different treatment protocols focusing the individual situation of the breast cancer patient are discussed.

Palliative radiotherapy is an important treatment option in metastatic breast cancer. There can be achieved long lasting improvement of tumor induced symptoms affecting the quality of life of breast cancer patients.

\section{IS068}

\section{Radiotherapy induced late side effects}

Feyer, P., Höller U.

Vivantes Klinikum Neukölln, Klinik für Radioonkologie, Berlin

The therapeutic range in tumour therapy protocols is well defined. The goal to achieve a maximal tumour cell reduction is limited by acute and late side effects caused by radiotherapy as well as by chemotherapy.

Therefore the definition of the treatment plan and communication with the patient before starting the tumour specific therapy are of importance. Temporary side effects have been accepted in relation to the benefit risk calculation.

In radiotherapy there is a large variety of influencing factors defining the extent of acute and late side effects. There are patient related factors like comorbidities, treatment modalities before starting radiotherapy (surgery, chemotherapy or other systemic therapy), simultaneous therapies as well as radiotherapy specific factors ( single and total dose, irradiated volume and organs included)

The radiosensitivity of the different tissues is well known and tolerance doses of the organs at risk should be careful accepted in order to prevent handicaped late side effects.

Beside using modern treatment planning techniques, new irradiation modalities (particle therapy, image guided radiotherapy, respiratory guided radiotherapy, intensity modulated radiotherapy) it is not possible to prevent late side effects in every case.

It is of increasing importance to prevent and minimize late side effects with respect to the better survival rates in order to ensure a good quality of life for the patient.

Radiotherapy induced late side effects can be manifested from 6 months up to $10-15$ years after radiotherapy.

Of importance are skin and mucosal reactions with fibrosis and atrophia, dysfunction of the thyroidal and salivary glands, pulmonary and gastrointestinal manifestation of late effects. Especially attention should be drawn to the gonadal function in young patients. New treatment protocols with targeted therapies and biosimilars need a good cooperation of radiation and medical oncologist.

Secondary malignancies after $10-15$ years (incidence 3-5 \%) causes a long term follow up of irradiated patients.

Radiobiological mechanisms and treatment options are discussed.

The best way to ensure a good quality of life in long term survivors is the prevention of the damage causing late side effects. Additional supportive care treatment support this strategy.

\section{IS069 \\ Spätfolgen der Radio- und Radiochemotherapie an Haut und Subkutangewebe}

\section{Höller U., Feyer, P.}

Vivantes Klinikum Neukölln, Klinik für Radioonkologie, Berlin

Die Fibrose ist eine entscheidende Spätfolge der Strahlentherapie an zahlreichen Organen. Sie gleicht einer niemals heilenden Wunde. Die Fibrose ist ein dynamischer Prozess, der in drei Phasen verläuft: die präfibrotische inflammatorische, die konstituierende zellreiche/fibrotische Phase und die späte fibroatrophe Phase. In einem selbstunterhaltenden Prozess kommt es zu vermehrter terminaler Differenzierung von Fibroblasten und Produktion von Kollagen. Die Kenntnis des Mechanismus auf molekularer und zellulärer Ebene eröffnet in Zukunft die Möglichkeit, gezielt die Entwicklung der Fibrose zu verhindern oder diesen Prozess umzukehren. Tumor growth factor $\beta$
(TGF $\beta$ ) und das System der reactive oxidative /nitrogen species (ROS/RNS) spielen eine Schlüsselrolle.

Tierexperimentell wurden Antikörper gegen TGF $\beta$ und TGF $\beta$-Rezeptoren erfolgreich zur Prophylaxe der fibrotischen Reaktion z.B. der Lunge eingesetzt. In ersten klinischen Studien bei Mammakarzinom-Patientinnen reduzierten die Antioxidantien Pentoxyfillin/Tocopherol und Superoxiddismutase subcutane Fibrosen. In einer kleinen, Placebo-kontrollierten Phase II-Studie reduzierte die prophylaktische Gabe von Pentoxifyllin, das TNF $\alpha$ herunterreguliert, die klinische Pneumopathierate. Kontrovers wird der Radioprotektor Amifostin, der u.a. als Radikalenfänger wirkt und zytotoxische Substanzen inaktiviert, beurteilt. Im Gegensatz zu kleineren Studien reduzierte Amifostin in einer großen Phase IIIStudie die Häufigkeit der aktuen Pneumonitis und Fibrose nach Radiochemotherapie des Lungenkarzinoms nicht.

Im Rahmen kombinierter Radiochemotherapien werden verstärkte Strahlenreaktionen beobachtet. Der Einsatz neuer Substanzen (small molecules, Biologicals) verändert das Nebenwirkungsspektrum. Das Management von Hautreaktionen unter und nach Strahlentherapie muss adaptiert werden. Das klinische Bild der verschiedenen Reaktionsmuster und die geeigneten Pflegemaßnahmen werden vorgestellt.

Korrespondenz

Ulrike.hoeller@vivantes.de

\section{IS070}

\section{Role of oxidative signalling in activation-induced cell death of $T$ cells}

Krammer, P.H.

German Cancer Research Center, Tumor Immunology Program D030, Heidelberg

During the immune response, $\mathrm{T}$ cells activated by engagement of their T-cell receptor (TCR) undergo rapid proliferation and differentiation. In turn, termination of an immune response requires elimination of activated $\mathrm{T}$ lymphocytes (ATC) by a process of programmed cell death (apoptosis), called activation induced cell death (AICD). In AICD CD95 (Apo-1/Fas) ligand (L) triggers apoptosis of CD95 positive ATC.

Recently, oxidative signalling events following TCR stimulation were identified. However, their role in AICD is still unclear. Therefore, the relevance of the oxidative signal and intracellular $\mathrm{Ca}^{2+}$ signals for regulation of CD95L expression was analyzed. Here, we show that it is hydrogen peroxide $\left(\mathrm{H}_{2} \mathrm{O}_{2}\right)$ that functions as an essential second messenger in T cell receptor (TCR) signalling. Abrogation of the oxidative signal by addition of the antioxidant, $\mathrm{N}$ acetyl-cystein (NAC), can downregulate CD95L expression and rescue cells from AICD. Consequently, oxidative signals are necessary for activation of oxidation-dependent transcription factors $\mathrm{NF \kappa B}$ and $\mathrm{AP}-1$, which are crucial regulators of $\mathrm{CD} 95 \mathrm{~L}$ expression. Finally, we show that the $\mathrm{H}_{2} \mathrm{O}_{2}$ signal combined with simultaneous calcium $\left(\mathrm{Ca}^{++}\right)$influx into the cytosol constitutes the minimal requirement for induction of CD95L expression. Either signal alone is insufficient.

Korrespondenz

h.sauter@dkfz-heidelberg.de

\section{IS071}

\section{Therapy of Myelodysplastic Syndromes (MDS) in elderly} patient

\section{Stauder R. ${ }^{1}$, Deschler B. ${ }^{2}$}

${ }^{1}$ Medizinische Universität, Innsbruck; ${ }^{2}$ Universitätsklinikum, Freiburg

Until recently, only very limited specific treatment options existed for elderly patients with MDS. These consisted primarily of best supportive care, growth factors and low-dose chemotherapy. There was and still is a clear need for innovative (ideally: targeted), specific therapy that takes into account particular aspects of older patients with hemato-oncological malignancies. We will summarize the most relevant progresses that are currently being made ranging from optimization of supportive care and innovative non-intensive treatment to reduced-intensity conditioning (RIC) allografting.

Transfusion strategies have been optimized in the last years taking into account special considerations of clinical judgement beyond mere transfusion 
below a defined haemoglobin value. Iron overload syndromes causing significant morbidity and mortality can be treated by chelator therapy including orally available compounds.

Epigenetic treatment with DNA demethylating agents (Decitabine, Vidaza) shows very encouraging results particularly in the high-risk group, the largest population that has been evaluated until now. Data for valproic acid are very promising regarding response rates in low-risk MDS patients. Finally, lenalidomide shows very convincing efficacy in MDS with the 5q-Syndrome (particularly in the absence of additional chromosomal aberrations).

RIC followed by allogeneic stem cell transplantation can be performed with curative intent at least until the biological age of 70 years, since it is increasingly understood that numerical age of is not of primary relevance.

With a long-awaited expansion of specific treatment options in MDS, choices are increasingly directed by MDS risk scores (IPSS, WPSS), cytogenetics, and of course the age-specific host factors such as performance status, comorbidities, all together defining biological age.

\section{IS072 \\ Komplementäre und alternative Methoden in der Onkologie: Die Situation in Europa}

Jungi, W.F.

Krebsliga Schweiz, Studiengruppe für komplementäre und alternative Methoden, Bern, Wittenbach

Es fällt schwer, die Situation betr. Verbreitung komplementärer und alternativer Methoden(KAM) bei Krebs in Europa zu erfassen. Vieles spricht dafür, dass sie in den letzten Jahren zugenommen hat, sichere Daten dazu liegen aber nicht vor. Die Ergebnisse zahlreicher entsprechender Untersuchungen in verschiedenen europäischen Ländern aus den letzten Jahren lassen sich nur schwer oder gar nicht vergleichen, zu hinderlich sind dazu Unterschiede in der Definition von KAM, in der Auswahl der Methoden, in der Zusammensetzung der Befragten und in der Methodik. Horneber hat versucht, die Zahlen der Krebspatienten, die KAM anwenden, für Europa zusammenzufassen und kommt dabei auf 39\%, mit grossen Unterschieden(Niederlande 18\%, Südeuropa 47\%) und Variationsbreiten (Europa 9-78\%). Eine gesamteuropäische Studie der European Nursing Society (Molassiotis, 2005) ergab gleichfalls stark divergierende Werte (z.B. 10\% UK, 38\% Italien). Eine Wiederholung dieser Befragung mit einheitlicher Methodik im Abstand einiger Jahre wäre sehr angebracht.

Ziel und Zweck all dieser Untersuchungen muss sein, die Bedürfnisse der von Krebs betroffenen Patienten besser zu erfassen, sie zu beraten, ihnen von angeblich alternativen, potentiell gefährlichen Methoden abzuraten und mit ihnen den Wert und die Verträglichkeit komplementärer Methoden in prospektiven Studien zu bestimmen.

\section{IS074}

\section{Breakthrough pain - Rules and new concepts of treatment}

Nauck, F., Eulitz, N., Alt-Epping, B.

Universitätsmedizin, Abt. Palliativmedizin, Göttingen

Cancer pain imposes a great burden on patients and results in considerable constraints limiting their quality of life. Basic analgesia for chronic cancer pain consists of non-invasively (orally) administered long-acting preparations of various analgesic and co-analgetic agents according to the WHO approved escalating schedule. This will lead to sufficient pain control in approximately 80-90\% [Rees 2002].

In addition to chronic pain, however, about $60 \%$ of cancer patients will experience breakthrough pain, implying rapid onset exacerbations of chronic pain, mostly described as moderate to severe in intensity [Mercadante et al. 2002]. Breakthrough pain poses great burden on quality of life and activity of patients and leads to distress also for the relatives. The exact diagnosis and assessment of different forms of breakthrough pain, including a comprehensive medical history, remains a therapeutic challenge. Rapid-onset and short acting preparations of highly potent opioids are available for the management of theses attacks, but require an adaequate administration of basic analgesia in appropriate doses and time schedules, and a sufficient patient compliance.

This lecture will explain new relevant aspects on diagnosis and therapy of breakthrough pain.

\section{IS075}

\section{Psychoonkologische Versorgung im Brustzentrum eines Akutkrankenhauses durch den integrierten psycho-onkologischen Dienst}

\section{Schönhals-Schlaudt, D., von Kries, $A$}

Dr. Horst-Schmidt-Kliniken, Wiesbaden

\section{Das Besondere einer ,Liaison zwischen POD und Brustzentrum}

Der Psychoonkologische Dienst (POD) ist eine zentrale Versorgungseinheit der HSK und somit auch für das Brustzentrum zuständig. Tätigkeitsbereiche des POD sind die Versorgung (Beratung/Therapie) der Patienten und Angehörigen, Entlastung und Schulung der Kollegen (Ärzte, Pflege) und Weiterentwicklung der Institution HSK. Die Integration des POD in die Strukturen und Versorgungsabläufe gewährleistet eine besondere Qualität. Einzelne Merkmale der besonderen Qualität sind: die Erreichbarkeit und Vertrauenswürdigkeit (für Patienten und Kollegen), der Informationsfluss, die Versorgungsangebote in allen Tätigkeitsbereichen. Die Versorgung des POD erstreckt sich auch in den Bereich der ambulanten Nachsorge und schließt die Vernetzung in der Region mit ein. Die Kenntnis der hausinternen Strukturen, Abläufe und der jeweiligen beteiligten Kollegen (von der Ambulanz bis zur Palliativstation), ermöglichen es dem POD initiativ auf akuten Bedarf, besondere Belastungen, Veränderungen im Ablauf zu reagieren und passgenaue Angebote gestaltend einzubringen. Dazu gehört auch ein in den medizinischen Ablauf integriertes Screening. Die Besonderheit der „Liaison“ wird durch ein Beispiel aus der musiktherapeutischen Arbeit gezeigt, die eine wichtige nonverbal-orientierte Ergänzung zum psychoonkologischen Gespräch darstellt.

\section{IS076}

\section{Patientengesteuerte Gewebebank am Beispiel von PATH}

Gallmeier I.

Stiftung PATH, Augsburg

PATH in brief stands for Patients Tumor Bank of Hope and is the first and only tumor tissue bank in the world that is fully organized and funded by breast cancer patients. With currently approx. 30.000 specimen of more than 3.000 patients PATH is one of the biggest tumorbanks in Europe for fresh frozen breast cancer tissue.

PATH Foundation is a non-profit organisation independent of economic interests and was incorporated to address the crucial lack of funding for clinical and genetic research, especially in the area of molecular pathology. PATH wants to bring lifesaving discoveries from the laboratory to the bedside of every woman suffering from breast cancer by supporting innovative research, specifically through the advancement of molecular pathology and breast cancer medicine. While we currently observe the funding of tumor banks in many places around the world PATH stands out in its approach. Essentially, researchers use the tumor banks to collect tissue for their research but at no benefit for the donating patient. We at PATH however believe that patients should be directly involved in the process and should benefit personally from the storage of their tissue.

The Idea: Once after surgery all diagnostic procedures are completed the tissue and blood serum left over is cut into pieces and deep frozen at temperatures below -150 degrees to guarantee durable safekeeping for several years. The first cut of tissue stays at the patient's disposal. Whenever she wants she can access it: In case of a recurrence, for instance, when new diagnostic approaches are developed and new options of treatment are available.

The other parts are donated to the tissue collection meant for research. Therefore the patient has both: a private benefit of her own tissue and the satisfaction of contributing to scientific progress in the area that personally affects her.

PATH was established in 2002 by the breast cancer advocacy group "mamazone as a unique joint-venture of patients, physicians and researchers aiming to support appliance-oriented cancer research.

The Actual Situation: Currently seven breast centers in Germany give patients access to this promising opportunity. Until today we have collected specimen (tumor and normal tissue and serum) of more than 3.000 patients, all processed after standardised SOPs. All patients have signed an informed consent created by Jochen Taupitz, member of the National board of ethics in Germany and checked by the ethics committee of the University Bonn. PATH is collecting patients data sets from the gynaecologists and pathologists in a centralized data base. The whole process has an acknowledge of the commission of data protection. 
Innovative Follow-Up: PATH contacts its patients on a regular basis via mail and phone for generating follow up data. Until now the compliance of this procedere is very high. It seems to be one of the most effective way to get follow up data.

IS078

\section{Effects of a structured physical exercise program in the rehabilitation of breast cancer patients with cancer- related fatigue: A randomized controlled study}

\section{Wuttke M. ${ }^{1}$, Niklas A. ${ }^{2}$, v.Steinbüchel N. ${ }^{3}$, Heim M.E. ${ }^{3}$}

${ }^{1}$ Sonnenberg-Klinik, Bad Sooden-Allendorf; ${ }^{2}$ Inst. f. Sportwissenschaften, Göttingen; ${ }^{3}$ Inst. f. Med. Psychologie, Göttingen

Background: Chronic fatigue is the most frequent complaint of tumor patients in rehabilitation. Several studies could document the positive effects of physical training in the rehabilitation of cancer patients, including improvement of cancerrelated fatigue. We present a prospective randomized controlled trial evaluating the effects of a structured program of aerobic and resistance exercises.

Patients and Methods: 140 breast cancer patients with fatigue symptoms will be asked to estimate their fatigue level on a Fatigue-LASA screening instrument. Patients fulfilling the inclusion criteria are randomized to a control group receiving the complex rehabilitation program according to the guidelines of the DRV, and an intervention group receiving in addition a structured areobic and resistance exercise program with a written instruction and the assignment to continue the training at home. The training time and number of exercises have to be documented continuesly. Patients in both groups were analyzed at 4 different points in time: $\mathrm{t} 1$ :beginning of rehabilitation, $\mathrm{t} 2$ : end of rehabilitation, $\mathrm{t} 3$ and $\mathrm{t} 4: 3$ and 6 months after $\mathrm{t} 2$. At $\mathrm{t} 1$ and $\mathrm{t} 2$ exercise tests measure the anaerobic capacity and muscle strength (Digimax muscle-functiontest). Patients are asked to complete the following questionnaires at t1-t4: MFI, FACT-G/F, EORTC-QLQ-C30, HADS,SF-12, adherencequestionnaire, and some questions about recent physical activity.

Conclusion: In a recently completed pilot-study (Heim et al. Onkologie 2007; 30:429-434) we could show a significantly reduced cancer-related fatigue in patients with a structured physical training program, even at the 3-month followup. In this study we will test if the improvement of fatigue and health-related quality of life can be sustained for a 6-month period.

Acknowledgement: This study is supported by a grant of the Deutsche Krebshilfe.

\section{IS079}

\section{Judgement bias in responding to questionnaires in patients suffering from cancer}

\section{Zenger M., Hinz A.}

Universitätsklinikum, Selbständige Abteilung für Medizinsche Psychologie und Medizinische Soziologie, Leipzig

The aim of this study is to examine different aspects of psychosocial burdens of cancer patients by means of questionnaires. Furthermore we want to reflect the quality of life and the general health status of these patients as well as their individual needs and requirements for psychological assistance. The main focus is on changes over time. In this field of research the scientific literature takes more and more into account the phenomenon of the so called 'response shift'. It means, for example, that changes of self-evaluations of individual health related quality of life are not only due to objective real changes of the health status, but also to changes in a cognitive manner, namely, changes in internal standards, values or in the whole concepts about a construct like health and disease.

This study will quantify the phenomenon of 'response shift', using the so called 'Then-Test' among others. Further results will be expected from the relationship between the psychological situation of cancer patients on the one hand and the psychosocial care as requested or realized on the other hand. Thus, the results can contribute to develop specific care programs for persons suffering from cancer. Patients with urological and gynaecological cancer tumours from five wards of the university hospital of Leipzig will be interviewed at three different times: during the stay in the hospital (T1), two weeks after discharge (T2) and three months later (T3).

This study aims at the evaluation of about 300 patients with complete data sets. Constituting parts of the questionnaire are among others the EORTC QLQC30, Life Satisfaction Questionnaire (FLZ), Hospital Anxiety and Depression Scale (HADS), Life Orientation Test (LOT) and Hornheider Screening (HS).
First results will be expected in October 2008 conforming to the application. Representative surveys of the general German population will be used for a better comparability and integration of the results.

Key words: Quality of life, psychological assistance, response shift

\section{IS080}

\section{Psycho-social adaptation of long-time survivors after cancer during adolescence}

\section{Goldbeck L., Besier T., Seitz D.}

Universitätsklinikum UIm, Kinder- and Jugendpsychiatrie/Psychotherapie, UIm

A cancer diagnosis and the related treatment are associated with various and sustained psychosocial burdens. American and Dutch studies with childhood cancer survivors showed an increased prevalence of posttraumatic stress disorder; regarding other mental disorders the evidence is still insufficient. Also, little is known so far about long-term psychosocial development and subsequent participation in society.

The aim of this study is to describe psychological distress, psychosocial development, life satisfaction and posttraumatic growth of German long-tem survivors after cancer during adolescence. This should help to identify indicators of a long lasting psychosocial (mal-)adaptation.

Based on the German Childhood Cancer Registry, 750 long-time cancer survivors will be compared to healthy peers and to normative reference scores. The inclusion criterions are (1) age of 15-18 years at first cancer diagnosis and (2) onset of cancer at least five years earlier than the beginning of this study. In a first step all participants are asked to fill in a questionnaire measuring psychological symptoms, posttraumatic growth, life satisfaction and achievement of milestones. In a second-step participants with a conspicuous psychopathology will be examined by a structured clinical interview via telephone to classify ICD-10 diagnosis. We present the rationale and the design of this epidemiological study. Funded by the "Deutsche Krebshilfe e.V." No. 107452

\section{IS081}

Improvement of communication skills of oncologists in explaining therapy options and clinical trials to cancer patients training concept and preliminary results

\author{
Wünsch A., Gölz T., Bertz H., Fritzsche K. \\ Universitätsklinikum Freiburg, Freiburg
}

Background: Physicians in oncology are obliged to inform patients about clinical trials in accordance to ethical and legal standards. Based on this information, the patient has to come to a decision whether to participate in a clinical trial. Physicians are, however, inadequately prepared for this task.

Objectives: Can a specific training for oncologists improve the conveying of key information about clinical trials (main objective)? Can this specific training increase the physicians' feeling of competence (objective 2) and the understanding of the concept of Informed Consent of the actor-patient (objective 3)? Methods: Physicians are randomly assigned to an intervention or a waiting control group. The intervention consists of a manualized training on conveying key information about therapy options and clinical trials. Training success is evaluated by comparison of 2 video-recorded consultations with actorpatients before and after training. Likewise, questionnaires are used to rate the physicians' feeling of competence and the understanding of Informed Consents by standardized patients.

Results: The training and evaluation concept as well as preliminary results are presented

IS082

Improving communication skills of oncologists in the transition from curative to palliative care training concept and preliminary results

\section{Gölz T., Wünsch A., Stubenrauch S., Bertz H., Fritzsche K. Universitätsklinikum, Freiburg}

Background: Consultations in which the transition to palliative care must be discussed pose a special type of problem: for oncologists, they are particularly 
stressful and patients and significant others want to be adequately informed and emotionally supported. This is best accomplished in patient-centered communication techniques.

Objectives: For this topic we have developed a specific communication training oriented to the individual learning goals of the participants and are examining the effect on conducting consultations (primary objective). Moreover, we are studying the effect of training on the physicians' experience of distress, on their self-ratings concerning the quality of their performance, on the satisfaction of patients and significant others with the consultations (secondary objective).

Methods: Physicians are randomly assigned to a training or waiting control group. The intervention consists of a 1.5-day workshop in small groups and includes practice consultings with actor-patients. The transfer to everyday practice is facilitated by 1:1 coaching after the workshop.

For the evaluation of the training, video-recorded, standardized consultations with actor-patients before and after training are analyzed using a specific checklist. The experience of distress, self-ratings concerning the quality of the consultations and patients' satisfaction with the consultations are evaluated using a questionnaire.

Results: The training and evaluation concept as well as preliminary results are presented.

\section{IS084}

Inhibition of Src tyrosine kinase reverts chemoresistance towards 5-Fluorouracil in human pancreatic carcinoma cells: An involvement of epidermal growth factor receptor signaling

\section{Ischenko I., Seeliger H., Camaj P., Guba M., Jauch K.-W.,} Bruns C.J.

Klinikum der Universität München, Chirurgische Klinik und Poliklinik Grosshadern, München

Purpose: Resistance to chemotherapy is believed to be a major cause of treatment failure in pancreatic cancer. Thus, it is necessary to explore alternative therapeutic modalities to overcome drug resistance in pancreatic cancer treatment. We tested the hypothesis that Src tyrosine kinase inhibition could augment the chemosensitivity of 5-Fluorouracil (5-FU)-resistant human pancreatic cancer cells to 5-FU.

Methods: Human pancreatic carcinoma cell lines AsPC-1 and L3.6pl and their 5-FU-resistant sublines $\mathrm{AsPC}_{5-\mathrm{FU} \text { RES }}$ and $\mathrm{L} 3.6 \mathrm{pl}_{5-\mathrm{FU} \text { RES }}$ were exposed to the combination of 5-FU and Src tyrosine kinase inhibitor PP2, and the proliferation was further analyzed by MTT Proliferation assay. Quantification of apoptosis was performed using propidium iodide staining. The levels of TS, dihydropyrimidine dehydrogenase (DYPD), epidermal growth factor receptor (EGFR), AKT, and MAPK were analyzed by immunoblotting and RT-PCR. The therapeutic efficacy of 5-FU in combination with PP2 was also tested in nude mice orthotopically xenografted with $\mathrm{AsPC}_{5 \text {-FU RES }}$ cells.

Results: Combination of 5-FU + PP2 reflected the chemotherapeutic sensitivity of $\mathrm{AsPC}_{5 \text {-FU RES }}$ and L3.6pl $1_{5 \text {-FU RES }}$ cells towards 5-FU. Pre-treatment with PP2 restored 5-FU-induced apoptosis in 5-FU-resistant cell lines. TS protein was overexpressed in 5-FU-resistant cells, however, decreased significantly following pre-treatment with Src kinase inhibitors PP2 or AZM475271. Furthermore, combination of 5-FU + PP2 significantly decreased the 5-FU-induced activation of EGFR-AKT pathway. Finally, PP2 in combination with 5-FU substantially decreased the in vivo tumor growth and inhibited metastases.

Conclusions: We have found that the overexpression of TS in both AsPC and L3.6pl resistant cells serves as a chemotherapy protective mechanism, however, 5-FU resistance can be reversed via indirect TS regulation by inhibiting Src tyrosine kinase. A potential mechanism of action of Src kinase inhibitors on 5-FU chemosensitivity might be linked to the inhibition of 5-FU-induced EGFR-AKT activation. Finally, our findings give a strong evidence for pursuing a strategy combining 5-FU with Src kinase inhibitors in pancreatic cancer therapy, at least in those tumors displaying resistance to 5-FU.

\section{IS085}

\section{Treating Fear of Progression (FOP) - Determinats for therapeutic success}

\section{Berg P. ${ }^{1}$, Duran G. ${ }^{2}$, Engst-Hastreiter U. ${ }^{3}$, Waadt $S .{ }^{2}$, Henrich G. ${ }^{2}$,} Herschbach $P{ }^{2}$

${ }^{1}$ Institut für Therapieforschung IFT, Psychotherapeutische Ambulanz, München; ${ }^{2} \mathrm{TU}$-München, Klinik für Psychosomatik und Psychotherapie, München; ${ }^{3}$ Rheumazentrum Wendelstein, Bad Aibling

Fear of progression (FOP) is a construct, which includes all kinds of fear connected to a possible worsening of a disease. Clinical experience and several studies have shown this fear to be one of the most important causes of distress in cancer-patients. It has to be differentiated from irrational fears and can affect quality of life in such an enduring way, that it has to be treated. The far reaching consequences of FOP lead to the development and psychometric testing of a specific questionnaire (FOP-Q; Herschbach et al. 2005) and conceptualisation and evaluation of a specific therapy for dysfunctional FOP.

Two therapeutic concepts were designed: one rather non-directive encounter group and one group based on cognitive behaviour therapy. In the first, patients select the therapeutic topics, share common emotional experiences and social support. In the latter, a patient learns to confront himself with his fear, learns to think it out and to cope with it. Both therapies aim at enabling the patient to manage his fear rather than to eliminate it, so that he can win back quality of life. The evaluation is based on a prospective control group design with external randomisation. The data (FOP-Q, HADS, FLZ «Xtags error: No such color: tag $\mathrm{c} »^{\mathrm{M}}$, SF-12) from 256 cancer- and 256 rheumatism-patients were evaluated. The measures were done pre, post, 3 and 12 month after treatment. We shall present the results of the therapy evaluation study. The data point at a significant and meaningful decrease of FOP-Scores over one year. Furthermore, determinants of Fear of Progression and determinats of therapeutic success will be discussed.

Literature: Herschbach, P., Berg, P., Dankert, A., Duran-Atzinger, G., EngstHastreiter, U., Waadt, S., Keller, M., R. Ukat \& Henrich, G. (2005). Fear of Progression in Diabetes Mellitus, Cancer and Chronic Arthritis - Psychometric Properties of the Fear of Progression Questionnaire (FoP-Q). Journal of Psychosomatic Research, 58, 505-511.

\section{IS086}

\section{Krebs und Chemotherapie im Alter}

\section{Naegele $M$.}

Uniklinikum, Freiburg

Aktuelle Zahlen über die demographische Entwicklung der Bevölkerung und über die Epidemiologie von Krankheiten in Deutschland sprechen eine eindeutige Sprache: Krebs wird bereits in der nahen Zukunft zur Volkskrankheit Nr. 1. Vor allem Menschen über 60 Jahren werden hiervon prozentual am meisten betroffen sein. Zahlen der Gesellschaft der epidemiologischen Krebsregister in Deutschland (Gekid 2006) zeigen, dass $2002 \mathrm{ca}$. 80\% der Krebsneuerkrankungen bei Menschen über 60 diagnostiziert wurden. Krebs entwickelt sich zur Alterskrankheit. Während Operation und Strahlentherapie beim alten Menschen häufig noch durchgeführt werden, wird eine Chemotherapie wegen einer höheren Toxizität bei geringem Nutzen häufig abgelehnt. Diese Annahmen sind jedoch widerlegt. Als sinnvolle Maßnahme wird die individuell angepasste Chemotherapie auf Grundlage eines umfassenden geriatrischen Assessment erachtet, bei welchem die Pflege mitwirkt. Sowohl das gegenwärtige Pflegeangebot sowie die Pflegequalifikation sind auf diese Entwicklung noch nicht eingerichtet. Wichtige Schritte in naher Zukunft müssen sein:

- Am Aufbau altersfreundlicher Strukturen in onkologischen Zentren mitzuwirken.

- Berücksichtigung von Konzepten der Pflege alter Menschen in der Gesundheits- und Krankenpflege.

- Der Altenpflege den Zugang zu spezifischen Qualifikationen in der onkologischen Pflege ermöglichen. Dies gilt auch für ambulant Pflegende.

- Aufbau eines Unterstützungsnetzwerks für den häuslichen Bereich, damit alte Krebskranke hier mit Ihrem Krankheits-, Therapie- und Symptommanagement besser umgehen können. 


\section{IS087}

\section{The European Oncology Nursing Society: A European network for nurses}

Foubert $J$.

European Oncology Society, Nursing, Brussels

Die EONS-Vernetzung auf Europäischer Ebene.

Jan Foubert, executive director EONS (European Oncology Nursing Society) The European Oncology Nursing Society (EONS), founded in 1984, is comprised of individual cancer nurses, national oncology nursing societies and institutions and agencies in Europe involved in cancer care.

The mission of the European Oncology Nursing Society (EONS) is to add value to the work of its individual members and societies in delivering care to patients with cancer.

It aims to assist in the promotion of developing healthy communities through influencing, research and education.

By now, over 240 individual nurses in Europe are EONS-members. More substantially, the EONS membership is composed of 34 national cancer-nursing societies in Europe, which represent 15,000 European cancer nurses. Furthermore, there are also 20 institutions and organisations co operating with EONS as associated member.

One of EONS' important activities is the accreditation of educational programs in cancer nursing.

The aim of the EONS accreditation team is to improve the quality of continuing education courses offered to cancer nurses throughout Europe and to provide a mark of professional recognition. This year accreditation has been updated in line with the EU Bologna agreement and the widening range of educational events and programmes that nurses attend. Accreditation forms have been developed for educational programme of study, educational events, educational resources for patients and distance learning educational programmes. EONS' strength lies in co-operation and collaboration with a range of multiprofessional organisations, helping to optimise the nursing contribution to cancer care. Underpinning this collaborative approach is the crucial relationship EONS must continue to develop with National Oncology Nursing Societies and individual nurses working with cancer patients.

To obtain further information on EONS, please contact the EONS Secretariat (eons.secretariat@skynet.be). The society website (www.cancerworld.org/ eons) is regularly updated and as such is an excellent source of information on activities as well as topics of interest to cancer nurses across Europe.

Die European Oncology Nursing Society (EONS) - Ziele und Aufgaben $\S$ Ziel: Qualität der Pflege und Betreuung von Personen mit einem erhöhten Krebsrisiko, einer Krebserkrankung oder nach der Heilung einer solchen in Europa zu verbessern.

$\S$ EONS fördert die Forschung, Weiterbildung und Praxis der onkologischen Pflege. $\S$ EONS entwickelte ein Curriculum für einen Weiterbildungsgang für diplomierte Pflegende in der Onkologie und bewertet Fort- und Weiterbildungskurse im Bereich onkologischer Pflege (Zertifizierung).

$\S$ Vorteil: Europaweite Anerkennung des Weiterbildungsganges in der Onkologie für Pflegende.

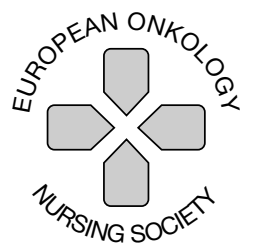

\section{IS088}

\section{Prevalence of psychological distress, mental disorders and their need for treatment in cancer patients - Quality assurance of assessment}

Härter M., Hund B., Reuter K.

Universitätsklinikum Freiburg, Freiburg

The department "Clinical Epidemiology and Health Services Research" at the University Medical Center, Freiburg will be responsible for providing the know how for structured clinical interviews within the multicenter study. Besides interview training and supervision for using the Composite International Diagnostic Interview (CIDI), this will also include conducting screening investifations in the clinics, and the editing of the computerized interview data. Moreover, a new diagnostic module for the assessment of adjustment disorders in somatically ill patients will be developed for the CIDI. Adjustment disorders are mental states of subjective suffering being diagnosed as a result of stress which affect emotional and behavioral reactions and disturb social functioning or professional capacity. Symptoms of an adjustment disorder are the following: depressive mood, anxiety, the feeling of being overwhelmed or problems in dealing with day to day life. In most cases isolated symptoms are being presented. Therefore, usually an adjustment disorder with depressive and/or anxious symptoms is diagnosed. So far, the structured and standardized clincial interview CIDI does not assessadjustment disorders. The development of the new module will rely on the operational criteria of the DSM-IV criteria for adjustment disorder and consider additional symptoma criteria relevant for diagnosis in patients with somatic diseases.

The module will be tested and validated within the design of the main study. It will be implemented from the second assessment wave on in the participating centers (Freiburg, Hamburg, Heidelberg, Leipzig, Würzburg). Therefore, approximately 1600 patients will be interviewed with the new module for adjustment disorders in addition to the CIDI.

\section{IS090}

Mental well-being and psychosocial support after partial resection of the larynx

\section{Singer S., Meyer A., Wollbrück D., Danker H., Schwarz R.}

Universität Leipzig, Sozialmedizin, Leipzig

Objectives: To present a new research project.

Background: Studies have shown that patients with head and neck cancer suffer more often from mental disorders than other cancer patients. Little is known about the specific influence of different surgery strategies on their psychological well-being. On the one hand, partial resection of the larynx usually leads to a better physical functioning and quality of life, so it should be assumed that the patients are less distressed than laryngectomees. On the other hand, there is always the possibility of tumour progress and therefore the adjustment could be poorer as well. Aim of this study is to evaluate the psychosocial well-being of those patients, to identify risk factors and to learn more about the amount and success of psychosocial aftercare.

Patients and Methods: Multicenter study. A consecutive sample of patients after partial resection of the larynx will be interviewed prospectively ( $\mathrm{t} 1$ : before surgery, t2: after surgery, t3: 12 weeks after surgery, t4: 1 year after surgery).

\section{Breast Cancer (Basic Research)}

\section{Oral Presentation}

\section{OP106}

No clinical relevance of standardized immuno-

cytological methods for detection of disseminated tumor cells in bone marrow of patients with primary breast cancer

Kaul S. ${ }^{1}$, Aggarwal M. ${ }^{1}$, Bartik B. ${ }^{1}$, Deckert A. ${ }^{2}$, Zeifang F. ${ }^{3}$, Bastert G. ${ }^{4}$, Fersis N.

${ }^{1}$ Universitätsfrauenklinik, Onkologisches Labor, Heidelberg; ${ }^{2}$ University, Inst. for medical biometry and informatics, Heidelberg; ${ }^{3}$ Orthopedic Clinic, Orthopedic Surgery, Heidelberg; ${ }^{4}$ Clinic for Oncology, Bad Trissl

Background: Bone marrow samples from 2017 patients operated for primary breast cancer (stage T1-4, N0/N+, M0) at the University Hospital Heidelberg between 1998 und 2004 were analysed for disseminated tumor cells (DTC) on cytospin slides using cytokeratin (CK) specific antibodies and the APAAP and SA-AP detection systems.

Material and Methods: Mononuclear cells were enriched by Ficoll densitygradient centrifugation. Cytospin-slides (mean 6) with $1 \times 10^{6} \mathrm{BM}$-cells (area $240 \mathrm{~mm}^{2}$ ) were air dried overnight. For immunocytochemical staining slides were fixed for $15 \mathrm{~min}$ in $3.5 \%$ buffered formalin at RT. Endogenous AP and Ig were blocked by incubation in $10 \%$ acetic acid and $2.28 \% \mathrm{NaJO}_{4}$. DTC were identified by $\mathrm{CK}$ antibodies 5D3, A45-B/B3, or AE1 + AE3 using automated 
Fig. 1. BM 4825, primary breast carcinoma, BM after neoadjuvant CHT, A45B/B3, APAAP, DakoTechmate 500, ACIS II Picture analysis, typical RS-type Stroma cells: area $<170$.

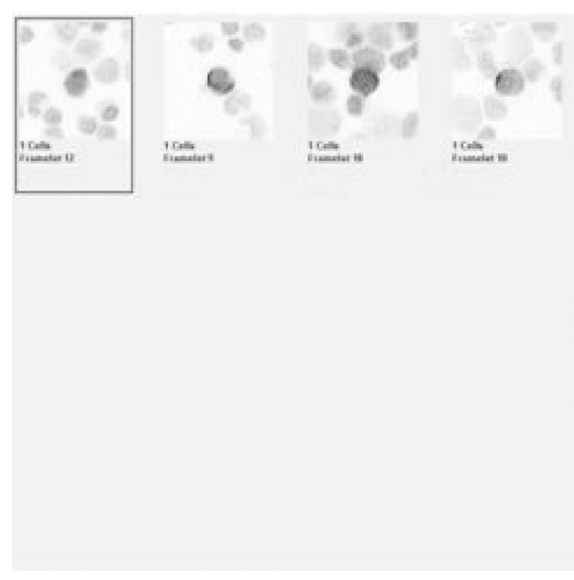

Fig. 2: BM 482, primary breast carcinoma,

A45B/B3, APAAP, DakoTechmate 500, ACIS II Picture analysis, tumor cells: area 309.

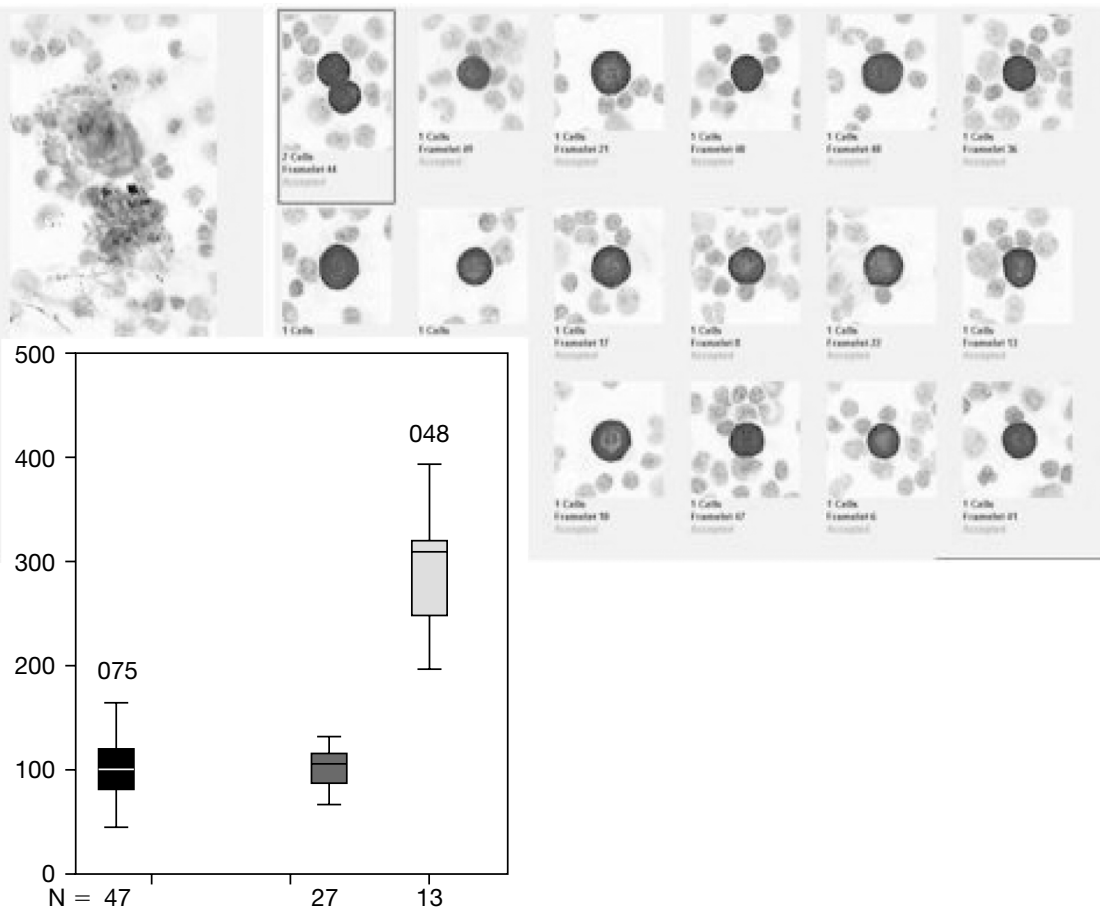

Table 1. Bone marrow samples from breast cancer patients 1998-2004

\begin{tabular}{|c|c|c|c|}
\hline \multicolumn{4}{|l|}{ University Hospital Heidelberg } \\
\hline \multirow[b]{2}{*}{ all samples } & \multirow{2}{*}{$\begin{array}{l}\text { Number (n) } \\
2775\end{array}$} & \multicolumn{2}{|c|}{ BM positive } \\
\hline & & $\mathrm{n}$ & $\%$ \\
\hline normal bone marrow & 84 & 0 & 0.0 \\
\hline no results/other Carcinomas & 37 & - & \\
\hline Metastatic breast carcinoma & 82 & 24 & 29.3 \\
\hline Secondary breast cancer & 83 & 5 & 6.0 \\
\hline Breast cancer recidive & 61 & 2 & 3.3 \\
\hline Breast cancer neoadjuvant & 351 & 8 & 2.3 \\
\hline Primary breast cancer & 2050 & 39 & 1.9 \\
\hline Prim. breast cancer $N O$ and $N+$ & 2017 & 26 & 1.3 \\
\hline Prim. breast cancer, $M 1$ & 33 & 13 & 39.4 \\
\hline Prim. breast cancer $\mathrm{MaCa}, \mathrm{N}+$ & 728 & 20 & 2.7 \\
\hline Prim. breast cancer $\mathrm{MaCa}, \mathrm{NO}$ & 1289 & 6 & 0.5 \\
\hline Prim. breast cancer $\mathrm{MaCa}, \mathrm{TO}+\mathrm{Tis}$ & 18 & 0 & 0.0 \\
\hline Prim. breast cancer $\mathrm{MaCa}, \mathrm{T1}$ & 1208 & 8 & 0.7 \\
\hline Prim. breast cancer $\mathrm{MaCa}, \mathrm{T} 2$ & 673 & 11 & 1.6 \\
\hline Prim. breast cancer $\mathrm{MaCa}, \mathrm{T} 3+4$ & 118 & 7 & 5.9 \\
\hline
\end{tabular}

immunostainers (Dako Techmate 500 and Ventana NEXES) with the APAAPand the enhanced SA-FastRed-method. Positive controls were routinely prepared by adding 50 tumor cells (breast carcinoma cell lines SK-BR3, HD1590 , HD-ZE) to $1 \times 10^{6} \mathrm{BM}$-cells either from clinical samples or from normal bone marrow donors. Slides were analysed by automated picture analysis with the ACIS I and ACIS II systems (ChromVision). Criteria for classification of disseminated tumor cells were in compliance with the publication of Fehm et al. (Cancer, Vol.107, 2006).
Results: Small cells characterized by an excentrically located small and clear nucleus were detected in $56 \%(475 / 850)$ of the bone marrow samples. These cytokeratin-positive normal bone marrow cells (Fig.1) were characterized by a mean area value of 102 (area $=$ cell size $\mathrm{x}$ staining intensitiy). Identical cell types were present in 27 samples from normal bone marrow donors. In contrast, tumor cells were characterized by strong and irregular cytoplasmic cytokeratin staining, a granular nucleus and a clearly enlarged nuclear size. These DTC (Fig.2) had a mean value for the parameter area of $309(n=13)$ according to the ACIS picture analysis. Using these tumor classification critera $26(1.3 \%)$ from 2017 patients with primary breast carcinoma were scored DTC positive (Table 1).

Discussion: We have shown that bone marrow stroma cells are positive for various epithelial antigens including CK. Elimination of these cells either by size exclusion in picture analysis or by immunomagnetic separation results in a tumor cell detection rates of less than $3 \%$ in $2 \times 10^{6}$ bone marrow cells. We conclude that cytological DTC analysis has no clinical relevance in patients with primary breast cancer.

\section{OP107}

\section{Normalized quantitative multi-gene expression analysis of Circulating Tumor Cells (CTC) in primary and metastatic breast cancer patients}

Fersis N., Koliogiannis D., Sisic L., Sohn C., Kaul S. Universitätsfrauenklinik, Onkologisches Labor, Heidelberg

Background: The purpose of this study was the validation of a new preanalytical enrichment and molecular detection method using embedded tumor cell calibrators (ETC) for quantitative gene expression analysis of circulating tumor cells (CTC) in breast cancer patients.

Methods: Samples from every patient were devided in native probes and matched calibrator probes containing either 2,4 or 8 breast carcinoma tumor cells (ETC). The high affinity antibodies BM7 (MUC-1) and VU1D9 (EpCAM) were used for immunomagnetic tumor cell enrichment in $10 \mathrm{~mL}$ of peripheral EDTA-blood of patients with primary breast cancer and metastatic disease. Separated cells were lysed and used for mRNA isolation and c-DNA synthesis. A new real-time quantitative RT-PCR approach using embedded tumor cells as internal calibrators for the markers cytokeratin 19 (CK19), 
Table 1

\begin{tabular}{|c|l|c|l|l|l|l|l|r|}
\hline Zeit & MUC & EpC & HER & CA153 & CK & SU & PSE & MG \\
\hline 0 & 0 & 0 & 0 & 18 & 0 & 0 & 0 & 0 \\
\hline 1 & 0 & 0 & 0 & & 0 & 0 & 0 & 0 \\
\hline 2 & 0 & 0 & 0 & & 0 & 0 & 0 & 0 \\
\hline 3 & 38 & 0 & 0 & 33 & 30 & 0 & 0 & 0 \\
\hline 4 & 0 & 0 & 0 & & 0 & 0 & 0 & 0 \\
\hline 5 & 0 & 0 & 0 & & 0 & 0 & 0 & 0 \\
\hline 6 & 0 & 0 & 6.4 & 24 & 9 & 0 & 0 & 0 \\
\hline 7 & 0 & 0 & 0 & & 0 & 0 & 0 & 0 \\
\hline 8 & 0 & 0 & 0 & & 0 & 0 & 0 & 0 \\
\hline 9 & 29 & 100 & 0 & 27 & 364 & 62 & 218 & 302 \\
\hline 10 & 0 & 0 & 0 & & 0 & 0 & 0 & 0 \\
\hline 11 & 0 & 0 & 0 & & 0 & 0 & 0 & 0 \\
\hline 12 & 28 & 164 & 10 & 168 & 285 & 50 & 174 & 674 \\
\hline
\end{tabular}

Fig. 1. HD-004: Zirkulierende Tumorzellen im Follow-up.

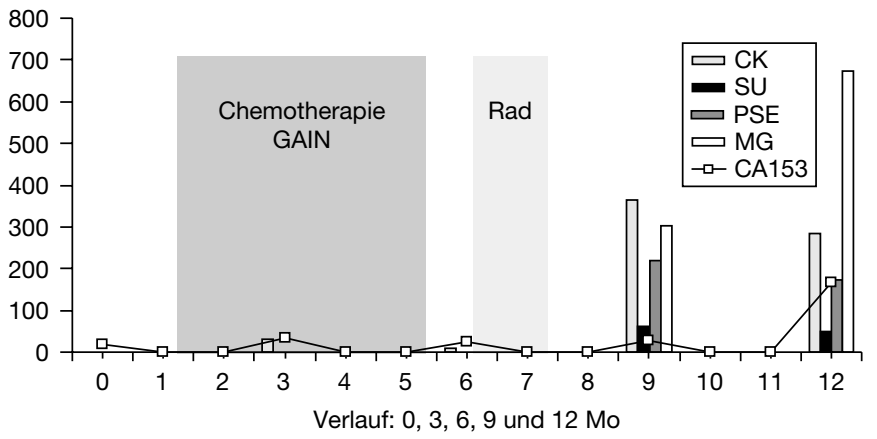

survivin (Sur), mammaglobin 1 (MG1) and prostate-specific ets factor (PSE), HER-2, CXCR4, Nanog, CD276 and FGFR2 was established using primers and FAM-labeled TaqMan probes selected with the UniversalProbeLibrary system (Roche AG, Basel, $\mathrm{CH}$ ).

Results: Positivity rate of ETC controlled realtime RT-PCR on the basis of CK19, MG1, Sur, and HER2 was $6.9 \%$ in 203 patients with primary breast cancer and $61.1 \%$ in patients with metastatic disease. Clonal selection or conversion from a HER2 negative (histology) to a HER2 positive phenotype was determined by qRT-PCR in 17 from $61(27.8 \%)$ patients. During a 18 months follow-up of 92 patients with primary breast cancer, multimarker positivity was determined in 10 patients, and in three of these patients early metastasis was clinically confirmed (Fig.1). In patients with metastatic disease CTCs coexpressed the tumor identifiers CK19, and MG1 together with Sur, PSE, Nanog, CD276 or HER2.

Conclusion: For the first time we describe embedded tumor cells as internal calibrators of accurate process control and normalization for the complex techniques of preanalytical immunomagnetic tumor cell enrichment followed by multigene quantitative RT-PCR approaches. The new techniques were validated at a sensitivity level of one tumor cell eqivalent in $5 \mathrm{ml}$ of blood. Tumor cell quantification and expression level of clinically relevant markers from the networks of apoptosis (Sur), tumor-specific angiogenesis (CD276) growth factor receptors (HER-2, FGFR2) and cytostatica resistence (ABCG2) may improve early detection of metastasis, monitoring of treatment regimes and prediction of (new) therapeutic targets.

\section{OP108}

\section{Relevance of stem cell like breast cancers for adjuvant endocrine treatment decision}

\section{Rody A. ${ }^{1}$, Holtrich U. ${ }^{1}$, Gätje R. ${ }^{1}$, Müller V. ${ }^{2}$, Gehrmann M. ${ }^{3}$,} Engels K. ${ }^{4}$, Loibl S. ${ }^{1}$, von Minckwitz G. ${ }^{1}$, Diallo R. ${ }^{5}$, Metzler D. ${ }^{6}$, Ruckhäberle E. ${ }^{1}$, Ahr A. ${ }^{1}$, Solbach C. ${ }^{1}$, Karn T. ${ }^{1}$, Kaufmann M. ${ }^{1}$ ${ }^{1} \mathrm{~J}$.W.Goethe Universität, Klinik für Gynäkologie, Frankfurt; ${ }^{2}$ University Hamburg-Eppendorf, Hamburg; ${ }^{3}$ Siemens Medical Solutions Diagnostics $\mathrm{GmbH}$, Molecular Research Germany, Leverkusen; ${ }^{4} \mathrm{~J} . W$. Goethe Universität, Pathologie, Frankfurt; ${ }^{5}$ Heinrich Heine-Universität, Pathologie, Düsseldorf; ${ }^{6} \mathrm{~J}$. W.Goethe Universität, Bioinformatik, Frankfurt

Background: Endocrine responsiveness is one of the most important characteristics of breast cancer. The negative association between expression of the estrogen receptor (ER) and proliferation detected in normal breast is frequently lost in breast cancers. It is not clear whether such different tumors develop during malignant transformation or are descendants from distinct progenitor cells.

Materials and Methods: Microarray data of 1369 breast cancers (test set $\mathrm{n}=171$, validation sets $\mathrm{n}=1198$ ) allowed the discrimination of "stem cell like" (SCL) tumors and Non-SCL tumors. The relationship of ER expression and proliferation was analysed in these subgroups.

Results: Two types of SCL tumors were identified which are characterized by their positive and negative ER status, respectively. While the inverse link of ER expression and proliferation is almost perfectly conserved within the SCL tumor groups it was "uncoupled" in nearly half of the ER positive Non-SCL tumors. These "uncoupled" tumors displayed high proliferation and a prognosis worse than that of ER negative cancers. Among untreated lymph node negative (LNN) patients these "uncoupled" ER positive tumors had a hazard ratio for disease recurrence of 1.82 (95\% CI, 1.28-2.57; P = 0.001) compared to the remaining ER positive tumors. Importantly, in endocrine treated LNN patients a hazard ratio of 7.86 (95\% CI, 2.81-21.97; $\mathrm{P}<0.001)$ for "uncoupled" tumors was observed.

Conclusion: Stratification of breast cancers according to the expression of stem/progenitor cell markers delineates ER positive tumors with an uncoupled link between ER and proliferation. This "uncoupling" corresponds to a poor prognosis and limits response to endocrine treatment.

\section{OP109}

\section{Prediction of emesis by polymorphisms in the serotonin} receptor subunit gene HTR3C - Rationale for an international prospective pharmacogenomics study Emesis 2 - CINV

Kollmannsberger B. ${ }^{1}$, Löhberg $C .{ }^{1}$, Stöhlmacher J. ${ }^{2}$, Wyen $C .^{3}$, Chua $D .{ }^{4}$, Niesler B. ${ }^{5}$, Stickeler E. ${ }^{6}$, Fehm $T^{7}{ }^{7}$, Janni $W^{8}{ }^{8}$, Schütz F. ${ }^{9}$, Schrauder M. ${ }^{1}$, Beckmann M. ${ }^{1}$, Nideracher D. ${ }^{10}$, Fasching $P{ }^{1}$

${ }^{1}$ Universität, Frauenklinik, Erlangen; ${ }^{2}$ Universität, Medizinische Klinik I, Dresden; ${ }^{3}$ Universität, Medizinische Klinik I, Köln; ${ }^{4}$ Universität, Hong Kong; ${ }^{5}$ Universität, Institut für Humangenetik, Heidelberg; ${ }^{6}$ Universität,

Frauenklinik, Freiburg; ${ }^{7}$ Universität, Frauenklinik, Tübingen; ${ }^{8}$ Universität, Frauenklinik Maistrasse, München; ${ }^{9}$ Universität, Frauenklinik, Heidelberg; ${ }^{10}$ Universität, Frauenklinik, Düsseldorf

Purpose: The aim of this study was to correlate chemotherapy-induced nausea and vomiting (CINV) in a cohort of breast cancer patients with commonly occurring single nucleotide polymorphisms (SNP) in the 5-hydroxytryptamine receptor 3 genes (HTR3).

Patients and Methods: Women with primary breast cancer who had not previously undergone chemotherapy were eligible for inclusion in this prospective study. All patients received treatment with epirubicin, with or without cyclophosphamide, and preventive medication with ondansetron and dexamethasone. The patients were asked to document every vomiting event on an hourly basis, in order to correlate the genotype with a complete response to antiemetic treatment and the time to the first emetic episode. Real-time polymerase chain reaction (PCR) analysis was performed for the following nonsynonymous SNPs: p.Y129S (HTR3B), p.K163N (HTR3C) and p.A405G (HTR3C). 
Results: Of 120 patients included, 110 were assessable. The overall proportion of patients who reported vomiting in the first 24 hours after chemotherapy was $31.8 \%(\mathrm{n}=35)$. The variant genotype of K163N (HTR3C) was strongly associated with vomiting (chi-squared test for an association with complete response, $\mathrm{P}=0.009$; and $\log$-rank $\mathrm{P}$ value for the time to first emetic episode, $\mathrm{P}=0.005$ ).

Conclusion: The newly discovered subunit of the serotonin receptor, $5-\mathrm{HT}_{3 \mathrm{C}}$, plays a major role in the pathogenesis of CINV. Polymorphisms in the HTR3C gene could serve as a predictive factor for CINV in patients undergoing moderately emetogenic chemotherapy. Results like these from experimental pilot studies have to be evaluated in a larger clinical setting. We designed a prospective, multicentric and multinational pharmacogenetic study with a planed sample size of 950 patients. It will be conducted as a collaborative work of the AGO and the AIO. Chemotherapy na've patients who receive a moderately emetogenous chemotherapy will be eligible for this study.

\section{OP110 \\ Increased risk of contralateral breast cancer for BRCA1 mutation carriers compared to BRCA2 mutation carriers}

\author{
Graeser M. ${ }^{1}$, Engel C. ${ }^{2}$, Zaino M. ${ }^{2}$, Schmutzler R. ${ }^{3}$, German \\ Consortium of Hereditary Breast and Ovarian D.K.F. ${ }^{4}$ \\ ${ }^{1}$ Universität Köln, Frauenheilkunde und Geburtshilfe, Köln; \\ ${ }^{2}$ Universität Leipzig, Institut für Informatik, Statistik und Epidemiologie, \\ Leipzig; ${ }^{3}$ Universität Köln, Abteilung für molekulare Gynäko-Onkologie, \\ Köln; ${ }^{4}$ Deutsches Konsortium, für familiären Brust und Eierstockkrebs, \\ Deutschland
}

Background: Women who carry a BRCA1 or BRCA2 mutation face a lifetime risk for breast cancer $(\mathrm{BrCa})$ of $80 \%$. Once diagnosed with breast cancer, the 10 year risk of contralateral (cl) breast cancer averages $40 \%$ for BRCA1 and BRCA2 mutation carriers. Prophylactic bilateral oophorectomy (PBO) and tamoxifen reduce the risk of clBrCa. As a result women may opt for $\mathrm{PBO}$ and prophylactic bilateral mastectomy (PBM). We here aimed at estimating the influence of BRCA1 versus BRCA2 mutation on clBrCa.

Patients and Methods: We conducted a retrospective cohort study in 986 index patients (pts) collected within the German Consortium of Hereditary Breast and Ovarian Cancer (GC-HBOC). 656 pts carried a deleterious BRCA1 mutation and 330 carried a deleterious BRCA2 mutation. Kaplan-Meier analysis was used to estimate the time between initial diagnosis and $\mathrm{clBrCa}$. Pts were followed from the initial diagnosis of breast cancer until clBrCa was diagnosed or censored at time of prophylactic cl mastectomy, death or date of last visit. Median age at first diagnosis was 41.8 years (range 17.5 to 80.5 ). Median age at first breast cancer was 39.8 years for BRCA1 mutation carriers (range 17.5 to 79.0) and 45.7 years (range 23.4 to 80.5 ) for BRCA2 mutation carriers. The hazard ratio (HR) was estimated using multivariate Cox regression analysis adjusting for age at first breast cancer and prophylactic bilateral oophorectomy (PBO).

Results: In the univariate analysis the cumulative risk of clBrCa was $21 \%$ (95\% CI 17 to 24 ) at 5 years and $38 \%(95 \%$ CI 33 to 43 ) at 10 years for BRCA1 mutation carriers and $11 \%(95 \%$ CI 6 to 15$)$ at 5 years and $29 \%(95 \%$ CI 21 to 36) at 10 years for BRCA2 mutation carriers. In the multivariate analysis, the HR was 1.5 for BRCA1 mutation carriers versus BRCA2 mutation carriers (95\% CI 1.12 to 2.03). Also, age at diagnosis of the first primary was significant in the univariate analysis (HR $0.9895 \%$ CI 0.96 to 0.99 ) and marginal significant in the multivariate analysis (HR $0.9895 \%$ CI 0.97 to 0.99). PBO was not significantly predictive.

Conclusion: We report here for the first time a 1.5 -fold increased risk for clBrCa in BRCA1 mutation carriers compared to BRCA2 mutation carriers. These results can now be used for counselling to allow a better decision on the basis of individual risk estimations.

\section{OP125}

\section{The renin-angiotensin-system controls angiogenic activity in hormone-receptor negative breast cancer}

\section{Herr D. ${ }^{1}$, Rodewald M. ${ }^{1}$, Fraser H.M. ${ }^{2}$, Hack G. ${ }^{1}$, Konrad R. ${ }^{1}$,} Kreienberg R. ${ }^{1}$, Wulff $C .{ }^{1}$

${ }^{1}$ Universitaet UIm, Frauenklinik, Ulm; ${ }^{2}$ The Queen's Medical Research Institute, Medical Research Council Human Reproductive Sciences Unit, Edinburgh

Background: Efforts have been undertaken to find new ways to target tumor growth such as inhibition of angiogenesis, which is needed to connect the growing tumor to a blood supply. Cancer cells have been proposed to regulate their gene expression in order to ensure their own nourishment. One of the main angiogenic regulators is vascular endothelial growth factor (VEGF). Thus, targeting VEGF by application of VEGF-antibodies has become an approach in anti-angiogenic therapy. The Renin-Angiotensin-System (RAS) system has been suspected not only to control the vascular tone but also to regulate angiogenesis via influencing VEGF.

The present study examined the role of the RAS in human breast cancer and attempted to determine whether inhibition of Angiotensin II receptor type 1 $\left(\mathrm{At}_{1} \mathrm{R}\right)$ could target tumor angiogenesis.

Methods: Expression of different RAS components in receptor positive and receptor negative human breast cancer tissue was investigated using immunofluorescence. Furthermore, RAS expression in receptor positive (MCF-7) and receptor-negative (MDA-MB 468) breast cancer cells was investigated performing immunocytochemistry and RT-PCR. For functional analysis, both cell lines were stimulated with Angiotensin II and $\mathrm{At}_{1} \mathrm{R}$ blocker Candesartan, and gene expression of VEGF, Angiopoietin 1 and 2 (Ang-1 and Ang-2), tissue inhibitor of matrix metalloproteinases 1 (TIMP-1), and hypoxia inducible transcription factor 2a (HIF-2a) was quantified by TaqMan-Real-Time PCR. Results: Angiotensin II and $\mathrm{At}_{1} \mathrm{R}$ were detected in hormone-receptor negative and positive human breast cancer tissue. In addition, the RAS components Angiotensinogen, Angiotensin I-converting enzyme (ACE), and $\mathrm{At}_{1} \mathrm{R}$ were expressed in MDA-MB 468 and MCF-7 human breast cancer cells. Furthermore, we found expression of VEGF, Ang1, TIMP-1, and HIF-2a in both cell lines.

In receptor negative MDA-MB 468 but not in MCF-7 breast cancer cells, Angiotensin II significantly increased gene expression of VEGF, HIF-2a, and TIMP-1. This effect was completely inhibited by administration of Candesartan.

Conclusion: In conclusion, we suggest that Angiotensin II may be involved in regulation of tumor angiogenesis especially in receptor negative breast cancer by regulation of angiogenesis associated genes via $\mathrm{At}_{1} \mathrm{R}$. These findings are the first evidence for targeting tumor angiogenesis by inhibition of $\mathrm{At}_{1} \mathrm{R}$ in receptor negative human breast cancer cells and may lead to new therapeutical anticancer strategies based upon inhibition of $\mathrm{At}_{1} \mathrm{R}$.

\section{OP126}

\section{Prediction of nodal involvement in breast cancer based on multiparametric protein analyses from preoperative core needle biopsies of the primary lesion}

\section{Sauer G. ${ }^{1}$, Schneiderhan-Marra N. ${ }^{2}$, Kurzeder C. ${ }^{1}$,} Kreienberg R. ${ }^{1}$, Joos $T^{2}{ }^{2}$, Deissler $H^{1}{ }^{1}$

${ }^{1}$ Universität, Frauenklink, UIm; ${ }^{2} \mathrm{NMI}$, Reutlingen

Identification of molecular characteristics that are useful to define subgroups of patients fitting into differential treatment schemes are considered most promising approaches in cancer research. During the last years, methods for a parallelized quantification of proteins by multiplexed sandwich immunoassays have become available as potential tools to define expression profiles indicative of clinically relevant properties of malignant tumors.

In this first study of this type, we analyzed lysates prepared from large core needle biopsies of 113 invasive breast carcinomas with bead-based miniaturized sandwich immunoassays specific for 54 pre-selected proteins. Five of the measured protein concentrations (FGF-2, Fas, Fas ligand, TIMP-1, RANTES) were calculated to be significantly different in the groups of patients with (N1) or without (N0) axillary lymph node metastasis. All 15 protein parameters that resulted in p-values below 0.2 and other diagnostic information (ER status, 
tumor size and histological grading) were analysed together by multivariate logistic regression. This yielded sets of 5 (FGF-2, Fas, Fas ligand, IP10, PDGF-AB/BB) or 6 (ER staining intensity, FGF-2, Fas ligand, MMP-13, PDGF-AB/BB, IP10) parameters for which ROC (receiver-operator characteristics) analyses revealed high sensitivities and specificities (AUC (area under curve) $=0.75$ and $\mathrm{AUC}=0.83$ ) to predict the nodal status. A similar analysis including all identified parameters of potential value (15 proteins, ER staining intensity, T) without selection resulted in a ROC curve with an AUC of 0.87 . In summary, we clearly demonstrated that this approach can be used to quantify numerous proteins from large core needle breast biopsies accurately in parallel and define sets of proteins whose combined analyses allow the prediction of nodal involvement with high specificity and sensitivity.

\section{OP127}

Clinical relevance of ten BRCA1 and three BRCA2 intronic germline mutations in families with hereditary breast and/or ovarian cancer

\section{Wappenschmidt B., Köhler J., Bosse K., Versmold B.,} Schmutzler R.K.

Unifrauenklinik für Frauenheilkunde und Geburtshilfe, Abt. Molekulare Gynäko-Onkologie, Köln

Summary: Next to heterozygous frameshift mutations in $B R C A 1$ or $B R C A 2$ leading to premature termination, intronic alterations potentially affecting the splice mechanism were identified in patients with hereditary breast and/or ovarian cancer. Even if previously described in BIC mutation database, the clinical relevance of intronic alterations is often unknown. Here, we describe the classification of ten distinct BRCA1 and three distinct BRCA2 intronic germline mutations by mRNA analysis.

Methods: Since 19971229 families fulfilling the criteria for hereditary breast and/or ovarian cancer were screened for BRCA1 and BRCA2 mutations by denaturing high performance liquid chromatography (DHPLC) followed by direct sequencing analysis. Patients with intronic alterations localized max. 20 bp up- or downstream from exonic boundaries were characterized on mRNA level taken from blood lymphocytes. RT-PCR was performed to examine correct splicing.

Results: We detected two novel $B R C A 1$ (IVS19+1delG, IVS21-1G/T) and three novel BRCA2 (IVS4-6del19, IVS5-8insT, IVS21-1G/T) intronic germline mutations not previously described. BRCAl IVS5+1G/T, IVS18+1G/C, IVS18-2delA, IVS21-1G/T and IVS22+2delT and BRCA2 IVS4-6del19, IVS5-8insT lead to aberrant transcripts. In contrast IVS1912G/A (BRCA1) does not disrupt normal splicing. Five intronic alterations (BRCA1: IVS4-18T/G, IVS5-12A/G, IVS18-6C/A, IVS19+1delG, BRCA2: IVS18-1G/T) are still under investigation and results will be presented.

Conclusions: So fare, five $B R C A 1$ and two $B R C A 2$ intronic alterations were considered to be causal for the disease. One BRCAl mutation seems to be neutral. These results now allow predictive genetic testing in families carrying a proven deleterious splice site mutation.

\section{OP128 \\ Mechanisms of micronuclei induction due to reduced repair capacity}

Varga D. ${ }^{1}$, Atassi Z. ${ }^{1}$, Vogel $W .{ }^{2}$, Kreienberg $R .{ }^{1}$, Sauer $G .{ }^{1}$

${ }^{1}$ Universität, Frauenklinik, Ulm; ${ }^{2}$ Universität, Humangenetik, Ulm

Background: An increased micronucleus (MN) frequency has been observed in irradiated peripheral lymphocytes of BRCA mutation carriers and sporadic breast cancer patients by the micronucleus assay. To assess the mechanism leading to higher MN frequencies in cancer patients, we performed FISH analysis on chromosomes 1,7 and 17 and terminal nick end labelling to detect MN with highly fragmented DNA.

Methods: Unselected sporadic breast cancer patients $(\mathrm{n}=140)$ and controls $(\mathrm{n}=149)$ were analysed by the G0 micronucleus test (MNT). On two probands with high $\mathrm{MN}$ frequency and on two probands with low MN frequency we performed FISH and Tunel assay analysis.

Results: Mean induced MN frequencies, showed significant differences between patients and controls, with an odds ratio (OR) of 5 to $10(\mathrm{p}$
Concerning Fish Analysis clastogenic effects represent the majority of MN induction, with the highest incidence in persons with high MN frequency. Conclusions: Most MN contain chromosomal fragments and probably arise from single DNA-double strand breaks. Our preliminary data also suggests an increase of MN with highly fragmented DNA in probands with high MN frequency, indicating that unrepaired DNA is exctruded into Micronuclei. This increase is probably caused by disturbed DNA repair in probands, but explains only a minor portion of the difference in MN frequency between patients and controls.

Both analyses, Fish and Tunel Assay, are probably capable to enhance the discriminative power of the MNT.

\section{OP129}

\section{Circulating Tumor Cells (CTC): Criteria for positivity in systems using immunomagnetic enrichment and quantitative surrogate multimarker analysis}

Sisic L., Kaul S., Weber A., Fersis N.

Universität, Frauenklinik, Heidelberg

Background: The purpose of this study was evaluation of different tumor identifiers for enumeration and quantitative gene expression analysis of circulating tumor cells $(\mathrm{CTC})$ in breast cancer patients.

Methods: The high affinity antibodies BM7 (MUC-1) and VU1D9 (EpCAM) were used for immunomagnetic tumor cell enrichment in $10 \mathrm{~mL}$ of peripheral EDTA-blood of patients with primary breast cancer (113 N0, $90 \mathrm{~N}+, 68$ neoadjuvant) and metastatic disease. Separated cells were lysed and used for mRNA isolation and c-DNA synthesis. The breast carcinoma-associated markers MUC1 and EpCAM were determined by endpoint RT-PCR. The markers cytokeratin 19 (CK19), mammaglobin 1, survivin, prostate-specific ets factor (PSE), CD276 and HER2 were amplified by real-time quantitative RT-PCR using primers and FAM-labeled TaqMan probes selected with the UniversalProbeLibrary system (Roche AG, Basel, CH). Specificity of the RTPCR was confirmed by examination of blood of healthy donors.

Results: The analytical lower limit of detection was two cells in $5 \mathrm{ml}$ blood with an assay recovery of $92.3 \%$. A panel of 9 breast cancer cell lines spiked in blood of normal donors and samples from patients with documented metastasis $(\mathrm{n}=121)$ were used to established optimal criteria for CTC definition. All positive samples were characterized by multimarker expression of CK19 or MG (= tumor identifiers) together with one or several of the other markers. Using CK19 and MG as tumor identifiers, patients with documented metastasis had a positivity rate of $61 \%$. For patients with primary disease (Table 1) a posivity rate of $6.9 \%$ was determined. The selection markers MUC1 and EpCAM, positive as single markers in more than $10 \%$ of the preoperative blood samples were useful only as verification markers.

Conclusion: Using a combination of preanalytical immunomagnetic tumor cell enrichment followed by a multigene quantitative RT-PCR approach we describe a sensitive detection system for rare circulating breast carcinoma cells. Based on the expression analysis of spiked tumor cells and from the results of samples from patients with documented metatasis $(n=121)$, we present criteria for CTC-positivity. In combination with the embedded tumor cell calibrator technique (Koliogiannis, DKK 2008) a reliable system for cell enumeration and quantitative expression analysis of survivin, PSE, CXCR4, CD276, mTOR and HER2 is provided for the field of rare tumor cell characterization. 
Table 1. Expression profile of CTC in 38/203 (18.7\%) marker-positive patients with primary breast carcinoma (T1-4, N0/N+, M0)

\begin{tabular}{|c|c|c|c|c|c|c|c|c|c|c|c|}
\hline \multirow[b]{2}{*}{ PCR Nr. } & \multicolumn{2}{|c|}{ Endpoint RT-PCR } & \multicolumn{5}{|c|}{ Real-time RT-PCR UPL-FAM-probes } & \multicolumn{4}{|c|}{ Clinical stage } \\
\hline & ЕрСАМ & MUC1 & CK19 & MG1 & Sur & PSE & HER2 & $\mathbf{T}$ & $\mathbf{N}$ & $\mathbf{G}$ & Her2 \\
\hline 674 & + & + & + & + & n.d. & + & - & 1 & 0 & 1 & 1 \\
\hline 768 & - & + & + & + & + & - & + & 1 & 1 & 2 & 0 \\
\hline 58 & + & + & + & - & + & + & + & 1 & 0 & 1 & 0 \\
\hline 59 & + & + & + & - & + & + & + & 2 & 0 & 3 & 0 \\
\hline 1258 & - & + & + & - & - & + & + & 2 & 1 & 2 & 0 \\
\hline 1949 & - & + & + & - & + & - & + & 2 & 1 & 3 & 3 \\
\hline 2362 & + & + & + & - & - & - & - & 2 & 1 & 3 & \\
\hline 5 & - & - & - & + & - & + & - & 1 & 1 & 3 & 3 \\
\hline 230 & - & - & - & + & - & + & - & 1 & 1 & 2 & 0 \\
\hline 1915 & + & + & - & + & - & - & - & 2 & 0 & 2 & 0 \\
\hline 356 & - & - & - & + & - & - & + & 2 & 1 & 3 & 3 \\
\hline 217 & + & + & - & - & + & + & - & 2 & 0 & 2 & 0 \\
\hline 562 & - & + & - & - & + & + & + & 1 & 0 & 1 & 0 \\
\hline 492 & + & + & - & + & - & - & - & 1 & 0 & 1 & 0 \\
\hline 489 & - & + & - & - & - & - & - & 1 & 0 & 2 & 0 \\
\hline 490 & - & + & - & - & - & - & - & 1 & 0 & 3 & 0 \\
\hline 672 & - & + & - & - & n.d. & - & - & 1 & 0 & 3 & 2 \\
\hline 811 & - & + & - & - & + & - & - & 1 & 0 & 2 & 0 \\
\hline 870 & - & + & - & - & - & - & - & 1 & 0 & 2 & 0 \\
\hline 488 & - & + & - & - & - & - & - & 2 & 1 & 3 & 0 \\
\hline 564 & - & + & - & - & - & - & n.d. & 1 & 1 & 2 & 0 \\
\hline 771 & - & + & - & - & n.d. & n.d. & - & 1 & 1 & 2 & 0 \\
\hline 774 & - & + & - & - & n.d. & n.d. & - & 1 & 1 & 2 & 0 \\
\hline 790 & - & + & - & - & n.d. & n.d. & - & 1 & 1 & 2 & 0 \\
\hline 802 & - & + & - & - & - & - & - & 2 & 1 & 3 & 0 \\
\hline 825 & - & + & - & - & - & - & - & 2 & 1 & 2 & 0 \\
\hline 770 & - & + & - & & - & & - & 1 & 0 & 2 & 0 \\
\hline 812 & - & + & - & & & & - & 3 & 0 & 2 & 0 \\
\hline 863 & - & + & - & n.d. & - & n.d. & - & 2 & 1 & 2 & n.d. \\
\hline 798 & - & + & & - & n.d. & n.d. & - & 4 & 1 & 3 & 0 \\
\hline 1197 & - & + & - & & & & - & 1 & 0 & 2 & 0 \\
\hline 841 & - & + & n.d. & n.d. & - & n.d. & - & 2 & 1 & 3 & 0 \\
\hline 224 & + & - & - & - & - & - & - & 2 & 0 & 3 & 0 \\
\hline 772 & + & - & - & - & - & - & - & 1 & 0 & 3 & 0 \\
\hline 1609 & + & - & - & - & - & - & - & 1 & 0 & 1 & 0 \\
\hline 1607 & + & - & n.d. & - & - & - & - & 1 & 0 & 2 & 0 \\
\hline 766 & + & - & - & - & - & & - & 2 & 1 & 2 & 3 \\
\hline 30 & + & - & n.d. & n.d. & & & - & 2 & 1 & 3 & 0 \\
\hline
\end{tabular}

CTC criteria: CK19 or MG1 together with one or more additional markers

Results: 14/203 (6.9\%) CTC-positive patients

Selection marker MUC1 and EpCAM

Primary breast carcinoma:24/203 (11.8\%) positive only with MUC1 or EpCAM

\section{Breast Cancer (Basic Research)}

\section{Poster Exhibition}

PE501

\section{Influence of nitrogen atom position and substitution} pattern on the estrogenic and cytotoxic properties of two series of triarylpyrroles

Schäfer A.

Freie Universität Berlin, pharmazeutische Chemie, Berlin

Breast cancer is a frequent cause of death in women. About $70 \%$ of all breast tumors are estrogen receptor (ER) positive. As ER activation promotes tumor growth, it is important to find selective modulators for the estrogen receptor (= SERM). These ligands should antagonize estrogen effects in breast tissue but should have positive impact in bone and no side effects in uterus, which could be achieved by receptor subtype selectivity.

Estradiol (endogenous ligand) and diethylstilbestrol (synthetic molecule) display high affinity to the ER. They both bear two hydroxyl groups in a certain distance from each other which is necessary for receptor binding.

To explore how the hydrophobic core influences the estrogenic activity various tetrasubstituted heterocycles have been synthesized: pyrazoles, imidazoles, furans and pyrroles. We synthesized $\mathrm{N}$-arylated pyrroles (1) and $\mathrm{N}$-alkylated pyrroles (2) and evaluated their hormonal profile.

Of interest is the influence of the position of the nitrogen atom on receptor subtype selectivity and orientation of the molecule in the ligand binding domain. 
Fig. 1.

Estradiol<smiles>CC12CCC3c4ccc(O)cc4CCC3C1CCC2O</smiles><smiles>[R]c1c(-c2ccc(O)cc2)cn(-c2ccc(O)cc2)c1-c1ccc(O)cc1</smiles>

1

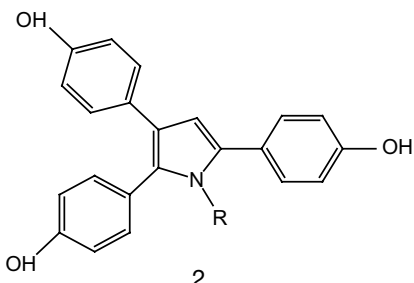

$\mathrm{R}=$ alkyl residue

Furthermore, the compounds were tested for cytotoxicity in MCF-7 and MDA-MB cells where they showed very weak to relatively strong cytotoxic effects, depending on the substitution pattern.

Future investigations include experiments on receptor subtype selectivity and ER down regulation as further criteria for hormonal activity.

\section{PE502}

The clinical relevance of small reactive $\mathrm{C} 1$ - and $\mathrm{C2}$ substances and steroid hormones in gynecological tumors

\section{Woitke K., Albrecht S., Distler W.}

Universitätsklinikum Carl Gustav Carus, Klinik und Poliklinik für

Frauenheilkunde und Geburtshilfe, Dresden

Breast cancer is the most common malignancy among women in industrialized countries. Every year 55.000 German women are diagnosed with a mamma carcinoma, whereas the peak of age lies between 60 and 65 years. Over 17.000 patients die every year.

The macromolecule cancer antigen 15-3 (CA 15-3) and carcinoembryonic antigen (CEA) are useful substances for diagnosis and prognosis.

Because of the complexity of the tumorgenesis, it is unlikely that one single substance meets the requirements for diagnosis, prognosis and judgment of the development of the carcinoma. Potential substances for the biochemical monitoring are $\mathrm{C} 1$ - and $\mathrm{C} 2$-molecules. These substances are generated during tumorgenesis. Examples are formiate, formamide, $\mathrm{CO}, \mathrm{CO}_{2}$, oxalate, glycolate, glyoxylate and acetate.

Oxalate can be detected in approximately 1 percent of all mineralization processes in mamma carcinomas. Oxalate micro calcifications seem to be a reliable indication for benign alterations and the lobular carcinoma in situ. Interleukin 6 is supposed to be associated with the process of metastasis and a shorter overall survival. While IL 18 is said to be associated with the process of metastasis, as well, IL 20 shows changes of its concentration when the tumor regresses.

We want to reveal the possible relevance of the biochemical marker oxalate and the interleukins IL 6, IL 18 and IL 20 for patients with the diagnosis of a mamma carcinoma, while having a look at the clinical status, the therapy and the well established tumor marker CA 15-3.

Our research includes 60 women with the diagnosis of breast cancer. The possible biochemical markers are detected in either fresh or preserved serum of the patients.

16 women are selected for the additional research on the relevance of interleukins for judging the outcome of the disease.

Our first results reveal a negative correlation of the biochemical marker oxalate with regard to the established tumor marker CA 15-3. A progression of the disease is often associated with a decrease of the concentration of oxalate in the serum.

\section{PE503 \\ Hypoxia-induced changes in Cyr61 (CCN1) - Alternative splicing}

Hirschfeld M., Jäger M., Stickeler E.

Universitäts-Frauenklinik, Molekulare Onkologie, Freiburg

Background and Aims: Alternative pre-mRNA splicing is a regulatory mechanism of gene expression to generate different protein isoforms under specific conditions. We investigated the Cyr61 gene expression particularly with regard to alternative pre-mRNA splicing and a potential conjunction with the strong hypoxia inducibility of this gene.

Methods: Expression profiles were determined in a matched pair analysis of malignant and normal tissues samples of patients with breast cancer or ovarian cancer (RT-PCR).

Hypoxia-induced alterations in alternative splicing patterns of the Cyr61 gene were examined in different tumor cell lines, followed by sequence analysis of the determined mRNA transcripts.

Results: The Cyr61 gene is subject to alternative splicing in cancerous and non-pathological breast and ovarian tissue. 2 different products were identified. Sequence analysis revealed the variation creating fragment, whose sequence argues for the incapability of the larger mRNA splice variant to generate an efficient Cyr61 protein, unlike the smaller variant. Alternative splicing originates from intron retention of intron 3-4 of the human Cyr61 gene. The $131 \mathrm{bp}$ intron sequence includes 2 stop codons. In vitro hypoxia entailed a significant shift in alternative splicing for the benefit of the shorter, presumably solely functional Cyr61 protein generating transcript. Hypoxia-induced changes in Cyr61 expression of splice variants were shown to be reversible after reversion to normoxia (rescue) in cultivated cell lines.

Conclusion: This study distinguishes the Cyr61 pre-mRNA as having 2 different alternatively spliced mRNA transcripts, whereas only the smaller variant seems to be capable of coding for a functional protein. Our results suggest that oxygen deficiency presumably leads to an increased expression of functional Cyr61 protein acting as a furtherer for tumor angiogenesis and neovascularization.

\section{PE504}

\section{Impact of VEGF on the expression of the endothelin axis} in human breast cancer cell lines

\section{Fischgräbe J. ${ }^{1}$, Götte M. ${ }^{1}$, Smollich M. ${ }^{1}$, Kiesel L. ${ }^{2}$, Wülfing $P{ }^{2}$ \\ ${ }^{1}$ Universitätsklinikum Münster, Frauenklinik-Forschungslabor, Münster; ${ }^{2}$ Universitätsklinikum Münster, Frauenklinik, Münster}

Background: The endothelin (ET) axis comprises two $\mathrm{G}$ protein-coupled receptors $\left(\mathrm{ET}_{\mathrm{A}} \mathrm{R}, \mathrm{ET}_{\mathrm{B}} \mathrm{R}\right)$, their ligands ET-1, ET-2 and ET-3, and three peptidases activating (ECE-1, ECE-2) and degrading (NEP) the endothelins, respectively. Of these, $\mathrm{ET}_{\mathrm{A}} \mathrm{R}, \mathrm{ET}-1, \mathrm{ECE}-1$ and NEP have been identified as prognostic markers in breast cancer. Moreover, in breast tumour tissue samples expression of ET-1 has been shown to correlate with the vascular endothelial growth factor (VEGF) expression and micro vessel density. In ovarian cancer, in vitro and in vivo studies have demonstrated a modulation of VEGF expression levels and tumour vascularisation upon stimulation/inhibition of $\mathrm{ET}_{\mathrm{A}} \mathrm{R}$. VEGF is known to play a crucial role in tumour angiogenesis. Proangiogenic effects of VEGF are mainly mediated via VEGF receptor 2 (KDR). Expression of VEGF itself is regulated by the hypoxia inducible factor HIF$1 \alpha$. Against this background, we studied potential interactions of the VEGF and ET pathways in breast cancer cells.

Methods: Various human breast cancer cell lines (MCF-7, MDA-MB-231, MDA-MB-468, SKBR-3, BT-474) were incubated with ET-1 (100 nM) and VEGF (100 ng/mL), respectively, in a time dependent manner $(2,8$, and 24 hours). Subsequently, gene expression levels of VEGF, KDR, HIF-1 $\alpha$, and ET-1, $\mathrm{ET}_{\mathrm{A}} \mathrm{R}, \mathrm{ECE}-1, \mathrm{NEP}$ were determined by quantitative real time PCR utilising the appropriate TaqMan ${ }^{\circledR}$ probe. In cell culture supernatants VEGF and ET-1 secretion levels were determined by ELISA.

Results: In neither cell line investigated, stimulation with ET-1 was capable of modulating VEGF, KDR and HIF- $1 \alpha$ gene expression. Also, there was no impact of VEGF on gene expression of the endothelin axis. Regarding protein secretion, VEGF has been shown to induce ET-1 secretion in SKBR-3 (125\%; $\mathrm{p} \leq 0.05)$ and MDA-MB-468 (110\%; $\mathrm{p} \leq 0.05)$ breast cancer cells. However, stimulation with ET-1 did not alter VEGF secretion. 
Conclusions: Our studies have shown that - in contrast to other tumour entities - there are only moderate, gene expression-independent interactions of VEGF and the ET-axis in breast cancer cells. Consequently, in breast cancer cells potential pro-angiogenic effects mediated by either pathway seem to be independent from each other.

\section{PE505}

\section{Characterization of primary high-risk breast cancer using target-oriented microarray analysis}

Tauchen A. ${ }^{1}$, Becker A. ${ }^{2}$, Faas-Fehervary P. ${ }^{3}$, Hornberg C. ${ }^{1}$, Volz J. ${ }^{3}$ ${ }^{1}$ Universität, AG7 Umwelt und Gesundheit, Fak. Gesundheitswiss., Bielefeld; ' Universität, Inst. f. Genomforschung und Systembiologie CeBiTec, Bielefeld; ${ }^{3}$ Städt. Klinikum Bielefeld-Mitte, Zentrum für Frauenheilkunde, Bielefeld

Gene expression profiling is widely used to identify new marker genes for prognosis and prediction of breast cancer. Different sets of genes have been published which are expected to provide a better basis for individualized therapies than routinely measured clinical parameters alone. Though the utility of expression profiles in breast cancer decision making is analyzed in different studies, there is little data confirming the reliability of this method compared to the classical risk factors. In our microarray expression study, we compare established clinical factors with gene expression profiles for a more detailed characterization of breast tumors. For target-oriented expression analysis a 70 mer oligonucleotide microarray containing 180 breast cancer related genes was designed. So far, 18 patients with primary breast cancer were included in this study. All of these high-risk patients have one or more of the following characteristics: poorly differentiated tumor (G3), negative ER, and regional lymph node involvement (N1). Core biopsies were taken before neoadjuvant chemotherapy in all cases. Additional tumor-related data like tumor size, Her2-neu- and progesterone receptor status are included in the analysis. In a first step, classification of tumors based on gene expression is done using unsupervised clustering methods. The gene expression profiles obtained are further analyzed regarding established clinicopathological factors to detect significant correlations. Both methods together give better tumor characterization and provide a good basis for further analyses due to tumor response in the neoadjuvant setting and disease outcome.

\section{PE506}

Molecular interactions of disseminated tumor cells with the microenvironment of the bone marrow

\author{
Schüler Y. ${ }^{1}$, Kaiser T. ${ }^{1}$, Fehm T. ${ }^{2}$, Klein G. ${ }^{1}$ \\ ${ }^{1}$ Universitätsklinikum Tübingen, Zentrum für Medizinische Forschung,
} Tübingen; ${ }^{2}$ Universitäts-Frauenklinik, Tumordissemination, Tübingen

Tumor cells such as breast cancer (BC) or renal cell carcinoma (RCC) cells preferentially metastasize to bone, commonly leading to the formation of osteolytic lesions. There is evidence that the bone marrow stroma, including osteoblasts, plays a crucial role in the homing of disseminated tumor cells However, the molecular interactions between tumor cells and the cellular and extracellular components of the bone marrow leading to bone tropism are not well understood.

Cell adhesion and cell migration assays using BC and RCC cell lines were performed to analyze in detail the influence of bone marrow components on the cellular functions of the different tumor cells. Cell-matrix adhesion assays revealed a strong and concentration-dependent attachment of different RCC and $\mathrm{BC}$ cell lines to several extracellular matrix components present in the human bone marrow such as collagens type I and IV, laminin-511/521, tenascin-C or fibronectin. The cellular receptors responsible for the observed adhesive interactions are currently under investigation. To analyze the influence of osteoblasts on tumor cell migration, two different cell migration assays using conditioned media of osteoblasts were performed. Firstly, a wound healing assay using both BC and RCC tumor cells clearly showed that osteoblasts secrete factors which lead to a faster closure of the wounds, indicating an enhanced migration ability of the tumor cells. These migration-inducing factors could be eliminated by using charcoal or by heating the conditioned media to $56^{\circ} \mathrm{C}$. The results indicate that lipogenic and proteinogenic components are certainly involved in the enhanced migration of tumor cells. Secondly, using the ibidi ${ }^{\mathrm{TM}}$ chamber with semi-solid medium, a directed migration of the tumor cells towards the osteoblast-conditioned medium could be observed. Whether the prominent expression of several matrix metalloproteinases synthesized by the tumor cells facilitates the observed migration is also under current investigation.

Taken together, these findings demonstrate not only an interaction of $\mathrm{BC}$ and RCC cell lines with matrix components of the human bone marrow but also an enhanced migration ability of the tumor cells due to factors produced by osteoblasts suggesting a possible mechanism for facilitated homing of tumor cells into bone.

\section{PE507}

\section{Analysis of single nucleotide polymorphisms in the promoter region of estrogen receptor beta gene in women with breast cancer}

Horn F. ${ }^{1,2}$, Elemenler E. ${ }^{1}$, Kriener C. ${ }^{1}$, Juhasz-Boess $I^{1}{ }^{1}$, Görse R. ${ }^{1}$, Hartmann A. ${ }^{3}$, Ortmann O. ${ }^{1}$, Treeck O. ${ }^{1}$

${ }^{1}$ Universitätsfrauenklinik, 93053 Regensburg; ${ }^{2}$ Universitätsfrauenklinik, Regensburg; ${ }^{3}$ Institut für Pathologie, Erlangen

Estrogens are involved in both normal mammary development and in breast carcinogenesis. A family history of disease and exposure to estrogens are major risk factors for developing breast cancer. The biological effects of estrogens are mediated by estrogen receptors, estrogen receptor alpha and the more recently discovered estrogen receptor beta. Genetic variations like single nucleotide polymorphisms (SNPs) in genes involved in estrogen biosynthesis, metabolism and signal transduction have been suggested to play a role in breast cancer risk. In this study we tested the hypothesis that polymorphisms in the promoter region of estrogen receptor $\beta$ (ESR2) gene may be associated with increased risk for breast cancer. We investigated three ESR2 promoter region polymorphisms, rs2987983, rs3020449 and rs3020450, for association to breast cancer risk. A total of 183 breast cancer cases and 147 controls were included in the study. We found an ESR2 promoter haplotype associated with increased risk in breast cancer patients $(\mathrm{OR}=1.76, \mathrm{p}=0.0068)$. Additionally, a slightly increased breast cancer incidence was observed among women carrying the homozygous TT genotype of ERb promoter SNP rs2987983 (OR 1.584, p = 0.01). Healthy women more frequently carried the heterozygous CT genotype of this polymorphism, suggesting that this genotype has a weak protective effect (OR 0.62, $\mathrm{p}=0.009$ ). Our data suggest that SNPs in the promotor region of ESR2 gene are able to affect breast cancer risk. These data further support the emerging hypothesis that ESR2 is an important factor in breast cancer development.

\section{PE508}

\section{Expression of PGRMC1 in breast cancer}

Wurster I. ${ }^{1}$, Adam G. ${ }^{1}$, Vogel U. ${ }^{2}$, Solomayer E. ${ }^{1}$, Wallwiener D. ${ }^{1}$, Fehm $T^{1}{ }^{1}$, Neubauer . $^{1}$

${ }^{1}$ University of Tübingen, Department of Obstetrics and Gynaecology, Tübingen; ${ }^{2}$ University of Tübingen, Department of Pathology, Tübingen

Background: In a proteomic screening approach we identified progesterone receptor membrane component 1 (PGRMC1) as a protein upregulated and posttranslationally modified in frozen ER-negative breast cancer tissue samples making PGRMC1 a potential therapeutic target. PGRMC1 is a $28 \mathrm{kDa}$ protein consisting of 194 amino acids and belongs to the "membrane-associated progesterone receptor" (MAPR) protein family.

Aim: The aim of this project is to characterize the potential biological function of PGRMC1 and its expression in breast cancer tissue.

Material and Methods: Posttranslational phosphorylation of PGRMC1 was investigated by differential 2D-PAGE in combination with phosphatase treatment. Several hybridoma supernatants specific for human PGRMC1 were generated and tested by western blot analysis and immune histochemistry for specificity. Tissue microarrays containing paraffine-embedded breast cancer specimen were labelled by multiple-fluorescence for PGRMC1 and estrogen receptor alpha or the hypoxia marker glucose transporter 1 (Glut-1) to investigate subcellular localization and coexpression, respectively.

Results: 2D-Page analysis revealed that PGRMC1 is posttranslationally phosphorylated. Western Blot analysis using hybridoma $5 \mathrm{G} 7$ produced a 
specific signal at the predicted molecular weight of $28 \mathrm{kDa}$. Labelling of tumor cells with $5 \mathrm{G} 7$ was blocked by preincubation of the hybridoma with recombinant protein. In immune fluorescence analysis myoepithelial cells were highly positive for PGRMC1. Besides that PGRMC1 is upregulated in Glut1 positive, hypoxic areas in ductal carcinoma in situ of comedo type. Immunohistochemistry suggests a discrete perinuclear microlocalization of PGRMC1 in breast cancer cells.

Conclusion: Our data suggest that PGRMC1 can be phosphorylated in vivo and may be upregulated by hypoxia in breast cancer.

\section{PE509 \\ Charakterisierung der Invasionsmaker LRRC15 und LRRC32 beim Mammakarzinom}

\section{Neuburger C., Wachtel Y., Solomayer E., Wallwiener D., Neubauer $H^{1}{ }^{1}$, Fehm $T^{1}{ }^{1}$}

Universitäts-Frauenklinik Tübingen, Labor Tumorprogression, Tübingen

Fragestellung: Das DCIS ist Präkanzerose des duktal invasiven Mammakarzinoms. Da Tumorzellinvasion die Voraussetzung für Metastasierung ist, an deren Folgen ein Großteil der Patientinnen verstirbt, sind die Etablierung von Präventionsstrategien und eine Verbesserung der Risikogruppenstratifizierung bei DCIS-Patientinnen dringend erforderlich. Ziel dieser Analyse war die nähere Charakterisierung von LRRC15 und LRRC32, die im Rahmen einer Mikroarray-basierten „Matched-Pair“-Analyse homogener DCIS- und IDC-Areale als hochreguliert im invasiven Karzinom identifiziert worden (Schuetz et al., Cancer Res. 2006;66:5278-86).

Methodik: Für "real-time" RT-PCR Experimente mit dem LightCycler 480 System (Roche) wurde das LightCycler 480 SYBR Green I Master Kit verwendet. Die analysierten Zelllinien sind unterschiedlich invasiv (MCF10A: nicht-invasiv, MCF-7: tumorigen, nicht-invasiv, MDA-MB-231: hoch-invasiv). Sequenzierungen wurden von der Firma Seqlab durchgeführt. Die Expressionsanalyse der beiden LRRC15-Isoformen erfolgte über klassische RT-PCR (Superscript II RNase Reverse Transcriptase und Taq DNA Polymerase, recombinant, Invitrogen). LRRC32-spezifische siRNA wurde in MDA-MB-231 Zellen transfiziert (Cell Line Nucleofector R Kit V und Nucleofector Device, Amaxa biosystems). Nach nachgewiesenem „Knockdown“ erfolgte eine Matrigel-basierte Analyse (BD BioCoatTM BD Matrigel Invasion Chambers, Becton Dickinson).

Ergebnisse: Im Vergleich zur MCF 10A Zelllinie ist die Expression von LRRC15 und LRRC32 in hoch-invasiven MDA-MB-231 Zellen stark erhöht. Bei LRRC15 wurde nachgewiesen, dass sich das offene Leseraster der genomischen DNA von MCF 10 Zellen im Vergleich zu der von MDA-MB-231 Zellen durch 10 Polymorphismen unterscheidet. Zwei dieser SNP's, die homozygot vorliegen, führen zu einem Aminosäure-Austausch und somit zu einer veränderten Proteinsequenz. Weiterhin wurden bei LRRC15 zwei Transkript-Isoformen nachgewiesen die, in unterschiedlich invasiven Zellen und in Normalgewebe und Invasivgewebe derselben Tumoren, unterschiedlich stark exprimiert sind. Die Suppression der Genexpression von LRRC32 in hoch-invasiven MDA-MB-231 Zellen führte zu einen Verminderung der Invasivität der Zellen, was in unabhängigen Versuchen bestätigt werden konnte. Schlussfolgerung: Bei LRRC15 sind auf Genomebene in unterschiedlich invasiven Zelllinien Polymorphismen nachweisbar und zwei TranskriptIsoformen des Genes sind in Zelllinien und Tumorgewebe verschieden stark exprimiert. Bei LRRC32 konnte eine direkte Korrelation von Expressionsstärke und Invasivität in vitro gezeigt werden. Unsere Daten weisen darauf hin, dass die beiden Transmembranproteine LRRC15 und LRRC32 interessante Kandidaten für eine weitere Validierung, im Bezug au die Entwicklung neuer Prognose- bzw. Therapiestrategien beim duktal invasiven Mammakarzinom, sind.

\section{PE510}

Co-expression of genes of the insulin- and estrogen signaling system and correlation with clinical parameters in breast cancer patients

\section{Pfeiler G. ${ }^{1,2}$, Wenzl G. ${ }^{1}$, Schmitz G. ${ }^{3}$, Hartmann A. ${ }^{4}$, Ortmann O. ${ }^{1}$, Treeck O. ${ }^{1}$}

${ }^{1}$ Universität, Klinik für Gynäkologie und Geburtshilfe, Regensburg; ${ }^{2}$ Universität, Spezielle Gynäkologie, Wien; ${ }^{3}$ Universität, Institut für klinische Chemie und Labormedizin, Regensburg; ${ }^{4}$ Universität, Institut für Pathologie, Regensburg

Obesity is thought to increase breast cancer risk both through high activity of estrogen metabolizing enzymes and by associated high insulin and glucose serum levels directly impacting on proliferation and apoptosis of breast cancer cells. In the present study, we investigated co-expression of genes of the insulin/ IGF axis and the estrogen signaling system in correlation to clinical parameters in collected breast cancer specimen. Breast cancer tissue and fasting serum was collected from 26 female patients. After microdissection of the frozen samples, RNA was isolated and expression of genes of the estrogenand insulin/IGF signaling was measured by real time RT PCR. Fasting insulin, glucose and C-peptide as well as estradiol serum level were analysed by ELISA. Insulin resistance was calculated by the HOMA method. Postmenopausal women older than 70 years showed significant higher expression of estrogen receptor (ER)a as well as steroid sulfatase (STS) and were more likely insulin resistant than premenopausal women younger than 50 years. A strong significant association between vascular/ lymphovascular invasion (L1, V1) and BMI as well as insulin resistance could be identified. Both, ERa and STS expression were significantly associated with expression of insulin receptor, IGFR1 and IGFBP4 but not IGFR2. Higher expression of IGFR1 was associated with a better histological grading, whereas higher expression of IGFR2 correlated with lymph node negativity. In conclusion, the observed co-expression of components of the insulin/IGF signaling with ERa and steroid sulfatase supports the hypothesis that a close cross talk between both pathways is present in breast cancer cells. The observed correlation of insulin resistance with vascular invasion encourages further studies on larger case numbers to further examine the relevance of this association in the clinical situation.

\section{PE511}

\section{Impact of a proinflammatory microenvironment on endothelial adhesion of breast cancer cells}

\section{Eichbaum M., Huwe S., Loebel C., Kaul S., Steinborn A.,} Sohn C.

${ }^{1}$ Universitäts-Frauenklinik, Heidelberg

Background: TNF- $\alpha$ induces the endothelial expression of several adhesion molecules, e.g. E-selectin during inflammatory reactions. The interaction of circulating tumor cells and E-selectin is presumably an important step during hematogeneous, especially hepatic metastasization of breast cancer cells. It was our aim to evaluate if breast cancer cells use this mechanism and in how far a meastasis-favouring proinflammatory microenvironment is induced by themselves.

Patients and Methods: Three different breast cancer cell lines (ZE, 1590, KM22) were studied, furthermore human epithelial mammary cells as control. TNF- $\alpha$ secretion of ANA I- macrophages was measured after stimulation by the studied cells (ELISA). A multi-cytokin-array was performed to determine the secretion of 42 different inflammatory cytokines by the studied cells. The adhesion of tumor cells to endothelium was studied using a HUVECMonolayermodell.

Results: All three breast cancer cell lines showed different cytokine secretion patterns. Especially, the secretion of MCSF, MCP-1, Il-6, Il-8 and VEGF was strong. After $8 \mathrm{~h}$ a significant increase in the secretion of TNF- $\alpha$ by ANA-Imacrophages could be found (ZE: 1.9 fold, 1590: 4.9 fold, KM22: 1.9 fold). After activation with TNF- $\alpha$, the HUVEC-monolayermodell demonstrated tumor cell adhesion to endothelium mediated by E-selectin.

Conclusions: Breast cancer cells secrete macrophage-stimulating cytokines and cytokines with impact on a proinflammatory tumor/ host-microenvironment. A proinflammatory microenvironment favours E-selectin mediated 
tumor cell adhesion to endothelium. The clinical relevance of this phenomenon has to be further studied in future preclinical and clinical trials.

\section{PE512 \\ Expression von YB-1 Protein und Effektivität der Dosis-intensivierung beim Hochrisiko-Mammakarzinom: 5-jahres Ergebnisse der WSG-AM-01 Studie}

\section{Gluz O. ${ }^{1}$, Kates R. ${ }^{2}$, Schmitt $M .^{2}$, Mengele K. ${ }^{2}$, Royer H.-D. ${ }^{3}$, Diallo-Danebrock R. ${ }^{4}$, Ting E. ${ }^{4}$, Mohrmann S. ${ }^{1}$, Schuett G. ${ }^{1}$, Poremba C. ${ }^{4}$, Nitz U. ${ }^{1}$, Harbeck N. ${ }^{2}$ \\ ${ }^{1}$ Universität Düsseldorf, Westdeutsche Studiengruppe, Düsseldorf; ${ }^{2}$ Technische Universität, Frauenklinik, München; ${ }^{3}$ Forschungsinstitut Caesar, Bonn; ${ }^{4}$ Universitätsklinik Düsseldorf, Pathologie, Düsseldorf}

Zielsetzung: Y-box binding Protein (YB-1), bekannt als onkogener Transkriptionsfaktor, ist assoziiert mit Hochregulierung von MDR, Beeinflussung von p53 und Wachstumsinduktion des aggressiven Mammakarzinoms. Die WSG-AM-01 Studie hatte einen signifikanten Vorteil für das ereignisfreie Überleben (EFS) und Gesamtüberleben (OS) für Tandem Hochdosistherapie (HD) vs. dosisdichte Standardtherapie (DD) beim Hochrisiko-Mammakarzinom gezeigt. Die vorliegende Studie untersucht die Interaktion zwischen dem multiresistenten YB-1-induzierten Phänotyp und der Effektivität verschiedener Dosiseffektivitätsstrategien innerhalb des Studienkollektives.

Methoden: 236 Tumoren (116 HD/120 DD) waren verfügbar für Konstruktion der Tissue Microarrays und Bestimmung molekularer Subtypen mittels k-clustering. Zytoplasmatisches YB-1 Staining wurde mit spezifischem Peptid-Antikörper untersucht und semiqualitativ nach Intensität gescort. Assoziationen zwischen Staining (stark vs. schwach/keine Expression) wurden mittels von Pearson Korrelation untersucht. Überleben wurde univariat mittels Kaplan-Meier ermittelt und mit log-rank Statistik getestet, multivariat wurde das Cox Model angewandt.

Ergebnisse: Nach medianer Nachbeobachtungszeit von 60 Monaten wurde der signifikante EFS und OS Benefit für HD bestätigt. In $60 \%$ der Tumoren wurde eine starke YV-1 Expression nachgewiesen.YB-1 korrelierte positiv mit basal-like und Her 2/neu Subtypen und weiteren Therapie-Resistenz-Markern, wie p53, S6, EGFR. YB-1 war prädiktiv für Ansprechen der HD sowohl hinsichtlich EFS $(H R=0.29, \mathrm{p}=0.001)$ als auch OS $(\mathrm{HR}=0.16, \mathrm{p}<0.001)$. Diskussion: Ein YB-1 induzierter therapie-resistenter Phänotyp ist prävalent bei basal-like/Her-2/neu Subtypen. Von allen untersuchten Markern korrelierte die YB-1 Expression am besten mit der HD Effektivität. Diese Ergebnisse verdeutlichen die potentielle Bedeutung der YB-1 Expression als Stratifikationskriterium für weitere dosis-intensivierte Studien sowie als mögliches Ziel der Behandlung des für konventionelle Therapieansätze resistenten Hochrisiko-Mammakarzinoms.

\section{PE513}

\section{ATM and p53 are potential mediators of chloroquine- induced resistance to mammary carcinogenesis}

\author{
Loehberg C. ${ }^{1}$, Thompson $\mathrm{T}^{2}$, Kastan $\mathrm{M}^{3}$, Maclean $\mathrm{K}^{3}$, \\ Edwards $D .^{2}$, Kittrell $F^{2}{ }^{2}$, Medina $D .^{2}$, Conneely O. $^{2}$, \\ Beckmann M. ${ }^{1}$, O'Malley $B^{2}{ }^{2}$ \\ ${ }^{1}$ University Hospital of Erlangen, University Breast Center for Franconia \\ Erlangen; ${ }^{2}$ Baylor College of Medicine, Cell Biology, Houston; ${ }^{3}$ St Jude \\ Children's Research Hospital, Department of Hematology-Oncology, \\ Memphis
}

The use of agents to prevent the onset of and/or the progression to breast cancer has the potential to lower breast cancer risk. B.W. O'Malley et al. have previously shown that the tumor suppressor gene p53 is a potential mediator of hormone (estrogen/progesterone $(\mathrm{E} / \mathrm{P})$ ) -induced protection against chemical carcinogen-induced mammary carcinogenesis in animal models. Here we demonstrate for the first time a breast cancer protective effect of Chloroquine (CQ) in an animal model. CQ significantly reduced the incidence of N-methyl$\mathrm{N}$-nitrosourea (NMU)-induced mammary tumors in our animal model similar to E/P-treatment. No protection was seen in our BALB/c p53-null mammary epithelium model indicating a p53-dependency for the CQ effect. Using a human non-tumorigenic mammary gland epithelial cell line, MCF10A, we confirm that in the absence of detectable DNA damage, CQ activates the tumor-suppressor p53 and the p53-downstream target gene p21, resulting in G1 cell cycle arrest. p53 activation occurs at a posttranslational level via CQdependent phosphorylation of the checkpoint protein kinase, ATM, leading to ATM dependent phosphorylation of p53. In primary mammary gland epithelial cells isolated from p53-null mice, CQ does not induce G1 cell cycle arrest compared to cells isolated from wild-type mice also indicating a p53-dependency. Our results indicate that a short prior exposure to CQ may have a preventative application for mammary carcinogenesis.

\section{PE514}

\section{Evaluation of estrogen and progesterone receptor, HER-2 and Topo lla in primary breast cancer and metastatic axillary lymph nodes}

\author{
Ataseven B. ${ }^{1}$, Michler D. ${ }^{1}$, Högel B. ${ }^{2}$, Beer M. ${ }^{2}$, Eiermann W. ${ }^{1}$ \\ ${ }^{1}$ Rotkreuzklinikum München, Frauenklinik, I. Gynäkologische/Geburtshilfe \\ Hauptabteilung, München; ${ }^{2}$ Pathologie München, München
}

Background: Systemic treatment of breast cancer depends on different criteria, e.g. tumor size, grading, receptor status, Her-2/neu-Score. Usually these determinators are carried out using primary tumor tissue based on the assumption that the markers do not change during metastatic progression. We studied the concordance of estrogen (ER) and porgesterone receptor (PR), Her-2 and Topo IIa in primary breast cancer tissue and lymph node metastases.

Methods: We used paraffin-embedded tumor tissue from 118 patients with at least one ipsilateral metastatic lymph node. Immunhistochemistry (IHC) was used to analyze ER, PR, Her-2 and Topo IIa in primary tumor and lymph node. In Addition, Her-2 and Topo IIa amplification was evaluated by Fluorescence In Situ Hybridization (FISH) and Chromogenic In Situ Hybridization (CISH) in all samples with HER-2 Score $2+13+$ by IHC.

Results: Discordant results were seen in 2,6\% (ER), 3,5\% (PR), 3,4\% (Her2), 3,5\% (Topo IIa) by IHC, respectively. However, using FISH and CISH, we found a complete concordance (100\%) of the Topo II $\alpha$ and HER-2 gene status between the primary tumor and the corresponding axillary lymph node.

Comparing FISH and CISH, our results show a higher sensitivity with CISH detecting amplification of Topo II $\alpha$, whereas there was no difference in the detection of HER-2.

Conclusions: High concordance (approximately 96\%) between primary tumor and metastatic lymph nodes of the examined biological markers was detected by Immunhistochemistry, and complete (100\%) concordance using FISH and CISH. Nevertheless we recommend routine determination of Her-2 at metastatic lymph nodes, in order to treat all patients with Her-2 overexpression with trastuzumab. Regarding our results, HER-2 testing should be done with FISH, and Topo II $\alpha$ should be detected by CISH, in order to obtain the highest sensitivity.

\section{PE515}

\section{Increased wound-response revealed by proteomics of estrogen receptor-negative breast cancers}

Neubauer H. ${ }^{1}$, Clare S. ${ }^{2}$, Sotlar K. ${ }^{3}$, Wallwiener D. ${ }^{1}$, Cahill M.A. ${ }^{4}$, Solomayer . $^{1}$, Fehm T.

${ }^{1}$ University of Tuebingen, Department of Obstetrics and Gynecology, Tübingen; ${ }^{2}$ Indiana University School of Medicine, Division of Breast Surgical Oncology, Department of Surgery, Indianapolis; ${ }^{3}$ University of Tübingen, Department of Pathology, Tübingen; ${ }^{4}$ ProteoSys AG, Mainz

Background: The estrogen receptor (ER) $\alpha$ is found in $50-80 \%$ of breast tumors. While the mitogenic action of estrogens in breast cancer cells is well established, there is also evidence that ERs mediate protective, anti-invasive effects. Therefore, downstream ER-dependent proteins should be identified as possible targets to investigate and modify the mechanism of this phenomenon. Aim: The aim of this project was to identify proteins differentially expressed in fresh-frozen ER-positive and -negative breast cancer.

Methods: Whole tissue sections from eight ER-positive and eight ER-negative cryo-preserved breast cancer specimen were lysed and sub-pooled according to ER status into pools of two with normalised equal amounts of protein. 
These were analysed by differential multiplex ProteoTope imaging of 2DPAGE gels using $54 \mathrm{~cm}$ isoelectric focussing. This method is based on labeling proteins with chemically identical iodine radio-isotopes (I-125, I-131) and provides a direct quantitative and multi color differential proteome display at the low-attomole level. Spots were matched across gels, and their intensities were analysed relative to ER status. The statistically most significant differential protein spots were identified by mass spectrometry using picked comigrating non-radioactive tumor proteins.

Results: In total, proteins from 325 spots were identified by MALDI-TOF PMF with MASCOT scores greater than 70.72 spots represented 16 proteins that were identified in more than one protein spot. Proteins significantly differentially abundant across all pools at the $0.1 \%$ level were consistent with previously published literature. We observed elevated levels of keratins 19, 18 and 8 in ER-positive tumors suggesting a luminal phenotype for ER-positive tumors. Additionally, proteins associated with increased inflammation (immunoglobulin kappa light chain) and wound response (vimentin, apolipoprotein A1, cyclophilin A, transferrin,carbonic anhydrase, and PGRMC1) were observed in ER-negative tumors. The most highly differential abundant protein in ER-negative tumors relative to ER-positive tumors in our study was fibrinogen gamma A chain, followed by fibrin. Cancer-related fibrin deposition and fibrinolysis characterise many solid tumours, with cancer cells supplying many of the functions supplied by platelets in normal blood clotting. The deposition of fibrinogen without subsequent conversion to fibrin in the tumour stroma is reportedly a hallmark of breast carcinoma.

Conclusion: We demonstrate the applicability of ProteoTope, high resolution 2D-PAGE and sample pooling strategies for the discovery-directed differential quantification of complex proteomes from clinical samples. Our data are consistent with previously published literature, suggesting an altered keratin pool associated with increased inflammation and wound response in ER-negative tumors.

\section{PE516}

Molecular profiling and predictive value of circulating tumor cells in patients with metastatic breast cancer: An option for monitoring response to breast cancer related therapies

\author{
Tewes M. ${ }^{1}$, Wehling M. ${ }^{2}$, Welt A. ${ }^{1}$, Müller $S .{ }^{3}$, Hauch $S .{ }^{4}$, \\ Kimmig R. ${ }^{2}$, Kasimir-Bauer $S^{2}{ }^{2}$ \\ ${ }^{1}$ Universitätsklinik, Innere Klinik (Tumorforschung), Essen; \\ ${ }^{2}$ Universitätsklinik, Klinik für Frauenheilkunde und Geburtshilfe, Essen; \\ ${ }^{3}$ Kath. Marienkrankenhaus, Zentrum für Innere medizin, Hamburg; \\ ${ }^{4}$ AdnaGenAG, Langenhagen
}

Purpose: The purpose of the study was the molecular analysis of circulating tumor cells (CTC) in blood of metastatic breast cancer patients and to determine the ability of this method to predict the response to breast cancer related therapies.

Experimental Design: $10 \mathrm{ml}$ blood was obtained from 28 metastatic breast cancer patients before and during therapy. All patients had measurable disease and were either patients with relapse of breast cancer diagnosed years before and to start chemotherapy or patients with documented progressive breast cancer who were to begin a new endocrine, chemo-, trastuzumab- or experimental therapy. CTC were analyzed for EpCAM, MUC-1 and HER2 transcripts with the AdnaTest BreastCancer (AdnaGen AG). Expression of the estrogen $(\mathrm{ER})$ and progesterone (PR) receptor was assessed in an additional RT-PCR. The analysis of PCR products was performed by capillary electrophoresis on the Agilent Bioanalyzer 2100. Blood of healthy controls were used to confirm the specificity of the test.

Results: The overall detection rate for CTC was $64 \%$ (thereof $72 \%$ EpCAM; 78\% MUC-1; 33\% HER-2; 54\% ER; 23\% PR). CTC were ER, PR and Her-2 negative in $29 \%$ (ER), 66\% (PR) and 50\% (Her-2) of patients with receptorpositive tumors. Surprisingly, patients with receptor-negative tumors had receptor-positive CTC (40\% ER, 16\% PR and 50\% HER-2, respectively). A complete therapy monitoring could be performed in 20/28 patients. In summary, patients CTC positive either before or during therapy, showed a correlation between presence, persistence or early disappearance of CTC with therapy response in 16 cases, corresponding to a prediction rate of $80 \%$. The Kaplan Meier analysis showed a shorter overall survival for CTC positive patients indicating an additional and highly significant prognostic value of CTC detection $(\mathrm{p}<0.008) .10$ of the 20 patients remained positive for CTC
Fig. 1.

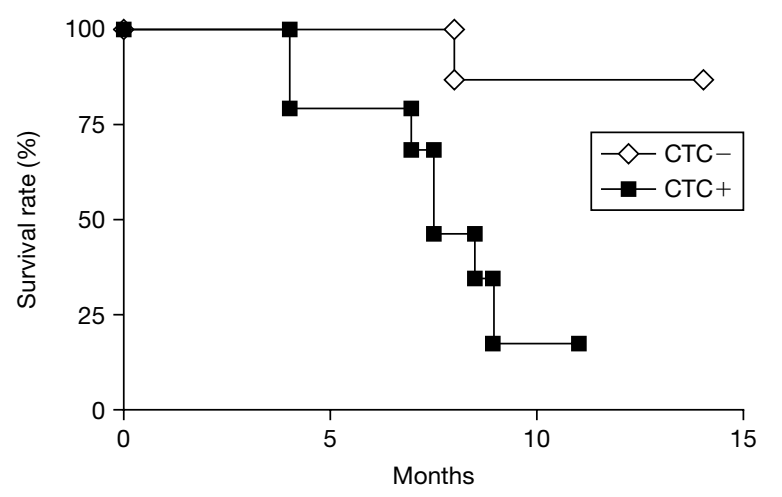

and 10 turned negative during therapy. During 12 months after therapy onset, 7 CTC positive patients have died in contrast to 1 patient of the CTC negative group.

Conclusions: The presence of CTC in metastatic breast cancer is a predictor of therapy response. Molecular profiling of CTC may offer more differentiated prognostic information with respect to higher accuracy of risk assessment for recurrence and towards predictive judgement of a response to therapeutic regiments.

\section{PE517}

Metabolic signature of breast cancer cell line MCF-7:
Profiling of modified nucleosides via Ic-it ms coupling

Neubauer $H .^{1}$, Kammerer $B .^{2}$, Bullinger $D .^{2}$, Laufer $S .{ }^{3}$, Gleiter C.H. ${ }^{2}$, Fehm T. ${ }^{1}$

${ }^{1}$ University of Tübingen, Department of Obstetrics and Gynecology, Tübingen; ${ }^{2}$ University Hospital Tübingen, Department of Pharmacology and Toxicology, Division of Clinical Pharmacology, Tübingen; ${ }^{3}$ University of Tübingen, Institute of Pharmacy, Tübingen

Introduction: Cancer, like other diseases accompanied with strong metabolic disorders, shows characteristic effects on cell turnover rate, activity of modifiying enzymes and DNA/RNA modifications, resulting also in elevated amounts of excreted modified nucleosides. For a better understanding of the impaired RNA metabolism in breast cancer cells, we screened these metabolites in the cell culture supernatants of the breast cancer cell line MCF-7 and compared it to the human mammary epithelial cells MCF-10A.

Methods: The nucleosides were isolated and analyzed via 2D-chromatographic techniques: In the first dimension by cis-diol specific boronate affinity chromatography and subsequently by reversed phase chromatography coupled to an ion trap mass spectrometer.

Results: Besides the determination of ribonucleosides, additional compounds with cis-diol structure, deriving from cross-linked biochemical pathways, like purine-, histidine- and polyamine metabolism were detected. In total, 36 metabolites were identified by comparison of fragmentation patterns and retention time. Relation to the internal standard isoguanosine yielded normalized area ratios of each identified compound and enabled a semi-quantitative metabolic signature of both analyzed cell lines.

13 of the identified 26 modified ribonucleosides were elevated in the cell culture supernatants of MCF-7 cells, with 5-methyluridine, $N^{2}, N^{2}, 7$-trimethylguanosine, $N^{6}$-methyl- $N^{6}$-threonylcarbamoyladenosine and 3-(3-aminocarboxypropyl)uridine showing the most significant differences. 1-ribosylimidazole-4-acetic acid, a histamine metabolite, was solely found in the supernatants of MCF-10A cells, whereas 1-ribosyl-4-carboxamido-5-aminoimidazole and S-adenosylmethionine occurred only in supernatants of MCF-7 cells.

Conclusion: The obtained results are discussed against the background of pathological changes in cell metabolism, resulting in new perspectives for modified nucleosides and related metabolites as possible biomedical markers for breast carcinoma in vivo. 


\section{PE518}

\section{Microarray analysis reveals prognostic significance of altered sphingolipid metabolism in breast cancer}

Ruckhäberle E. ${ }^{1}$, Rody A. ${ }^{1}$, Holtrich U. ${ }^{1}$, Engels $K^{2}{ }^{2}$, Schiffmann S. ${ }^{3}$, Grösch S. ${ }^{3}$, Geisslinger G. ${ }^{3}$, Gätje R. ${ }^{1}$, Ahr A. ${ }^{1}$, Karn T. ${ }^{1}$, Kaufmann M. ${ }^{1}$

1J.W.Goethe Universität, Klinik für Gynäkologie, Frankfurt; ${ }^{2} \mathrm{~J} . W$. Goethe Universität, Pathologie, Frankfurt; ${ }^{3}$ J.W.Goethe Universität, Klinische Pharmakologie, Frankfurt

Background: Sphingolipids play an important role in the regulation of proliferation and apoptosis of breast cancer cells as well as their response to therapy. A correlation of the estrogen receptor status of breast cancers with markers for apoptosis is known.

Material und Methods: We obtained gene expression profiles from a primary cohort of 171 invasive breast cancers using Affymetrix U133A microarrays. The expression of 43 genes linked to sphingolipid metabolism were analyzed and correlated to clinical and pathological parameters of the tumors. Validation was perfomed using expression profiling data of 1098 independent samples.

Results: The expression of various proteints connected to the sphingolipid metabolism is dependent on the estrogen receptor (ER) status of the tumor. Both sphingosine kinase 1 (SPHK1), Ganglioside GD3-Synthase and the Bcl2 interacting protein BNIP3 displayed higher expression among ER negative tumors. In contrast, glucosylceramidsynthase (GCS), LASS4, LASS 6 and ASAH1 revealed higher expression of those enzymes in ER positive samples. The 5 year disease free survival of patients with high SPHK1 was $65.7 \pm 3.7$ $\%$ while those of the patients with lower SPHK1 expression was $72.0 \pm 1.6 \%$ $(P=0.05)$. Since SPHK1 was correlated with ER negativity and a higher histological grading the different proportions of ER negative tumors in the groups with high and low SPHK1 expression could confound the clinical results obtained. Thus, a cohort of patients with ER positive tumors was analyzed. Also in this cohoert, those patients with ER positive tumors displaying high SPHK1 expression were characterized by a worse prognosis. To identify those cells expressing SPHK1 we performed immunohistochemical analysis of SPHK1 expression of samples previously profiled on Affymetrix microarrays. These analyses clearly identified the carcinoma cells of the major source of SPHK1 expression in the tumor tissue.

Discussion: Our results reveal that the sphingolipid pathways with the major metabolites ceramide, sphingosine and sphingosine-1-phosphat (S1P) display a clear correlation with the estrogen receptor status of the tumor. Moreover, patients with tumors with higher expression of SPHK1 had a worse prognosis. This could suggest a link of the role of ceramide as a biological mediator of antiproliferative effects as well as S1P as a proliferation promoting anti-apoptotic molecule with endocrine regulation of breast cancer.

\section{PE519 \\ "Stem cell like" breast cancers - A model for the identification of new prognostic/ predictive markers in endocrine responsive breast cancer exemplified by Plexin B1}

\section{Rody A., Holtrich U., Ruckhäberle E., Gätje R., Karn T., Kaufmann $M$. \\ J.W.Goethe Universität, Klinik für Gynäkologie, Frankfurt}

The identification of new biological markers for breast cancer has adopted a new dimension by the use of novel techniques such as global gene expression profiling. While important results have been achieved by these methods not all hopes for a more precise assessment of patients' prognosis have yet been accomplished and validation of prognostic or predictive gene signatures is still often difficult. Several recent approaches suggest that comparisons of differential gene expression could be more instructive if prior classifications of tumors based on molecular or biological characteristics were applied. We previously reported a subtype of breast cancer by using a cluster of coordinately expressed genes many of which has been associated with the mammary epithelial stem cells. While a stringent inverse link of ER status and proliferation of the tumor was observed among those "stem cell like" (SCL) tumors, this link was "uncoupled" in about half of the Non-"stem cell like" (Non-SCL) tumors. This subgroup of SCL tumors can be used as a reference system to analyse changes in the ER pathway by comparing the expression of genes dependent on the ER status.

By using this strategy we identified Plexin B1, a cell-surface receptor for the semaphorin Sema4D, whose expression is reduced in the group of "uncoupled" tumors. Loss of Plexin B1 is associated with an impaired prognosis in both univariate (all patients: $p=0.0062$; ER positive: $p=0.0107$ ) and multivariate analyses (all patients: $p=0.032$, ER positive: $p=0.022$ ). In conclusion those strategies of gene expression analysis in a context of biological meaningful classifications could be helpful to reveal new prognostic/predictive markers.

\section{PE520}

Overexpression of estrogen receptor $\beta$ in human breast cancer cell lines affects HER2/NEU expression in an ER $\alpha$-dependent manner

\section{Lattrich C., Treeck O., Juhasz-Böss I., Ortmann O.}

Universität, Frauenheilkunde und Geburtshilfe, Regensburg

Interactions between HER2 and the estrogen receptor $\alpha(\mathrm{ER} \alpha)$-signaling pathway have been described in breast cancer cells. Both, ER $\alpha$ expression and HER2 overexpression are important factors determining prognosis and therapy strategy of breast cancer. In this study, we intended to find out to what extent HER2 expression would be also modulated by ER $\beta$. To answer this question, we generated clones of the breast cancer cell lines MCF-7 and SK-BR-3 stably overexpressing ER $\beta 1$ by means of transfection and G418-selection. By RT-PCR and by Western Blot analysis the HER2 expression levels in these clones to the wild type cells were compared. ER $\alpha$-positive MCF-7 cells overexpressing ER $\beta 1$ exhibited significantly elevated HER 2 mRNA and protein levels. In contrast, HER2 mRNA levels were not changed in ER $\alpha$-negative, HER2 overexpressing SK-BR-3 cells. Treatment with ligand 17- $\beta$ estradiol diminished HER2 mRNA levels in MCF-7 WT cells, but upregulation of HER2 in ER $\beta 1$-overexpressing cells was still present under these culture conditions. Our data supporting previous reports describing a crosstalk between the estrogen- and HER2 signaling pathway suggest that ER $\alpha$-triggered suppression of HER 2 expression could be antagonized by ER $\beta 1$ in a ligand-independent manner. The clinical relevance of these in vitro data has to be confirmed in clinical studies analyzing co-expression of both receptors.

\section{PE521}

\section{Regulatory T-cells seem to play a central role in the immunescape in primary and metastatic breast cancer}

\section{Schütz F. ${ }^{1}$, Inzkirwili N. ${ }^{1}$, Beckhove P. ${ }^{2}$, Sohn C. ${ }^{1}$, Rom J. ${ }^{1}$ \\ ${ }^{1}$ Universität Heidelberg, Universitätsfrauenklinik, Heidelberg; ${ }^{2}$ Deutsches Krebsforschungszentrum, Immunologie, Heidelberg}

Tumorantigen-reactive Memory T-cells (MTC) are detectable in most of primary (PBC) and metastatic (MBC) breast cancer patients' bone marrow by using interferone-g-ELISpot-analysis. Patients with estrogen-receptor positive disease and well-differentiated tumors seem to have the highest incidence of MTC. Upon tumorantigen-stimulation they show TH1-responses by secreting INF-a. On the other hand TH1-suppression can be found in poorly-differentiated tumors by detecting TGF-b.

The question is why there is an immunoescape in ER+/G1-2 patients. FoxP3/CD25 ${ }^{+}$so called regualtory T-cells (Tregs) seem to play the most important role in influencing the incidence of tumorantigen-specific immunoresponses. By depleting Tregs from TAA-stimuluation cultures of 25 patients TH1-responses can be initiated in over $80 \%$ of the initial MTC negative patients. In MTC-positive patients INF-g responses can be multiplicated by factor 10. Furthermore significantly lower Treg frequencies can be found in PBCs' $\mathrm{BM}$ in comparison to their PB and to BM of healthy donors.

Tregs can be eliminated in vivo by metronomic cyclophosphamide therapy (50 mg p.o. per day). We perform an investigational study in heavily pretreated MBC patients to determine Tregs' frequencies under cyclophosphamide. 


\section{PE522}

\section{Adiponectin effects on gene regulation in human mammary epithelial cells and breast cancer cells}

\author{
Juhasz-Böss I. ${ }^{1}$, Buechler C. ${ }^{2}$, Neumeier M. ${ }^{2}$, Ortmann O. ${ }^{1}$, \\ Treeck O.
}

${ }^{1}$ Universität Regensburg, Klinik für Frauenheilkunde und Geburtshilfe, Regensburg; ${ }^{2}$ Universität Regensburg, Klinik für Innere Medizin, Regensburg

Serum levels of adiponectin, an adipocytokine, are inversely associated with breast cancer risk. Adiponectin influences estrogen levels and also is reported to exert direct antitumoral effects by inhibition of cell proliferation and increase of apoptosis of breast cancer cells. In this study, we intended to elucidate molecular mechanism underlying the antitumoral action of adiponectin For this purpose, we examined the effect of adiponectin on gene expression in a breast cancer cell line and a non-tumorigenic human mammary epithelial cell line. MCF-7 breast cancer cells and MCF-10A immortalized mammary epithelial cells were treated with adiponectin $(10 \mu \mathrm{g} / \mathrm{ml})$ for $48 \mathrm{~h}$. Adiponectin effect on gene expression was analyzed by means of DNA mircoarrays and then data was confirmed by real time PCR analysis of expression of estrogen receptor (ER) $\alpha, E R \beta 1, E R \beta 2, E R \beta 5$, caspase 1, TR2 orphan nuclear hormone receptor, adiponectin receptor 1 and ubiquitin specific peptidase 2 (USP2). In MCF-7 breast cancer cells adiponectin upregulated expression of ER $\beta 2$ gene about 6-fold, whereas no effect in regulation of other analyzed genes was observed. In contrast, in MCF-10A mammary epithelial cells adiponectin upregulated gene expression of ERb2 and USP2 more than 5-fold and mRNA levels of ER $\beta 5$, caspase 1 and TR2 were elevated about 2-fold. Treatment with adiponectin resulted in downregulation of adiponectin receptor 1 and ERb1 by about 30\% in this cell line. These findings suggest that adiponectin has different effects on breast cancer and mammary epithelial cells. Upregulation of $\mathrm{ERb}$ isoforms and caspase 1 which both are known to affect growth or apoptosis of breast cancer cells could be at least one molecular mechanism underlying the antitumoral action of adiponectin.

\section{PE523}

Web-based information and trial recruitment services for senological patients - www.brustkrebs-studien.de: The national web-portal of the German society of breast cancer

\section{Kansy J.K., Brucker S., Rajab T., Wallwiener M.}

Universität Tübingen, Universitätsfrauenklinik, Tübingen

Background: This study describes the way of one of the first comprehensive breast cancer health portals in Germany www.brustkrebs-studien.de providing patients with complete information about breast cancer, standard ways of treatment and clinical trials. In addition, a complete database with all current clinical trials tailored to the information level required by patients, a prototype for a national web-based recruitment system (BCRM) to recruit patients for these studies and a trial request service are available.

Objectives: The goal was to assess user interests and acceptance and the development of the portal after two years online.

Methods: We analysed numbers and hits of visitors from September 2005 to September 2007 for abolute numbers, user subgroups and fields of interest. Patient requests within the web service were analysed for categories. User acceptance was accessed via a paperbased evaluation questionnaire about the portal and its components $(n=46)$. Further trials were conducted to develop and establish the BCRM.

Results: Between September 2005 and September 2007, over 320.000 visitors accessed the portal.

The online breast cancer platform was widely used both by patients with over 191.000 visitors and more than 4.345 .000 sites visited and by health professionals with almost 130.000 visitors and more than 2.089 .000 sites visited within this period. Hits of sites were divided into over 4.000 .000 hits on sites about breast cancer, over 1.000 .000 hits on sites about standard treatment and over 1.200.000 hits on sites about clinical trials. The trial request service went online in September 2006. 83 requests were percieved, 65 (78\%) about adjuvant trials and $18(22 \%)$ about other trial categories. Patients' attitude towards clinical trials and trial participation as well as usage of the internet to obtain information is positive with $63 \%$ of patients willing to create an online health record.
Conclusions: This report shows that a significant number of patients are willing to search for information on clinical breast cancer trials and would use the internet for enrollment into clinical trials when a tool is available and a large proportion of people use the internet to get informed about breast cancer and different ways of treatment. Two years after its introduction www.brustkrebsstudien.de has become an important component of web-based oncological patient support.

Outlook: www.brustkrebs-studien.de will continue to evaluate, develop and improve its services, current focus is the BCRM recruitment tool.

\section{PE524}

Internet-based trial recruitment (BCRM): Analysis of compliance and information level of senological patients

\section{Kansy J.K., Wallwiener C., Kansy B., Rajab T., Wallwiener M.} Universität Tübingen, Universitätsfrauenklinik, Tübingen

Background: Trial recruitment remains one of the key factors determining scientific progress. Using computer- and web-based models to routinely screen patients for trial participation is a consequent step towards increasing recruitment rates. While most concepts put physicians into the center of this process, we aimed to analyze patients' ability and motivation to initiate this process.

Objectives: After having established one of the first comprehensive breast cancer health portals in Germany the aim of this study was to create a prototype for a web-based trial recruitment system (BCRM) and to evaluate patients' motivation and level of knowledge to use it.

Methods: To create a paperbased prototype of a standardised trial recruitment tool (BCRM), 50 breast cancer trials were analysed for participation criteria. Criteria were grouped into categories and translated into a questionnaire. The questionnaire was afterwards checked to cover trial criteria sufficiently. 50 patients were then asked to complete a paperbased version of the questionnaire.Subsequently, we compared this information with the patients' clinical record for correctness and completeness of information. In addition we asked patients to complete a questionnaire to analyze their attitude towards the questionnaire and trial participation. Ultimately we performed trial recruitment based an both patient information and clinical record and compared potential matches.

Results: The questionnaire on average represented $84 \%$ of trial criteria. Correctness and completeness of health information provided by patients was high with an average of $88.8 \%$ (correctness) and $70.4 \%$ (completeness). Results for potential trials using the BCRM prototype for information given by patients was on a par with results for clinical records. Patients' compliance towards clinical trial participation and internet-based recruitment is positive with $53 \%$ of patients potentially interested in trial participation and $65 \%$ of patients willing to use a web-based questionnaire to search for adequate trials. Conclusions: This report shows that a standardised recruitment tool for patients (BCRM) is feasable. A significant number of patients are both motivated and capable to use an internet-based trial recruitment tool.

Outlook: Based on these results, the portal will be extended by an improved computer-based matching system. An online prototype will be evaluated online for six months providing patients with accurate matches and register enrollment if patients successfully join clinical trials.

\section{PE525}

\section{Laminin-1 decreases estrogen receptor $\beta$ expression in breast cancer cells}

\section{Ruoff A., Wallwiener D., Solomayer E., Fehm T., Neubauer H.} University of Tübingen, Department of Obstetrics and Gynecology, Tübingen

Background: Estrogen receptor (ER) $\beta$ is involved in developmental processes of the mammary gland and also seems to play an important role in breast cancer. Conflicting data about ER $\beta$ in context with cell invasion are published. Up to now six splice variants of ER $\beta$ have been identified but the specific functions of these isoforms remain to be examined. It is known from the literature that basement membrane proteins can influence gene expression of the so far better characterized $\mathrm{ER} \alpha$. 
Aim: The aim of this project was to determine whether the expression of ER $\beta$ isoforms is influenced by extracellular matrix and basement membrane components.

Methods: Performing matrigel-assays standard cultured MDA-MB 231 breast cancer cells were plated on a coating layer of "Matrigel" BM Basement Membrane Matrix" which provides extracellular matrix conditions to the cells. As a control the same amount of cells was cultured on uncoated tissue culture plastic. To find out which specific extracellular matrix component the phenomenon is due to, we cultured cells on coatings with Laminin-1 and Collagen IV. ER $\beta$ expression was investigated after 24,48 and $72 \mathrm{~h}$ by classic multiplex PCR to distinguish between different isoforms. Additionally, invasion assay experiments were carried out to explore the expression pattern of ER $\beta$ isoforms in MDA-MB 231 cells.

Results: Cells cultured on a matrigel layer for $48 \mathrm{~h}$ showed a much lower expression of ER $\beta$ compared with cells cultivated without matrigel. Most of all ER $\beta$ isoform 1 was effected. In the invasion assay the non-invasive subpopulation of MDA-MB 231 cells showed reduced levels of ER $\beta$ 1, analogous to the expression pattern of cells plated on matrigel. The invasive subpopulation of MDA-MB 231 cells showed expression patterns of ER $\beta$ like cells on tissue culture plastic. Regarding the effects of specific basement membrane proteins, Laminin-1 could be identified to be the component which can be correlated with the distinct ER $\beta$ decrease while collagen IV was ineffective in maintaining ER $\beta$ levels. We further observed that MDA-MB-231 cells cultured on matrigel reorganized in tissue-like structures (acini) which appear very similar to lactiferous ducts.

Conclusions: These data suggest that the basement membrane component laminin-1 - perhaps by binding to its integrin receptors - inhibits the expression of ER $\beta$ in breast cancer cells by influencing the transcriptional machinery of the cells.

\section{PE526}

\section{Functional analysis of the Progesterone Receptor Membrane Component 1 (PGRMC1) in breast cancer}

\section{Neubauer H. ${ }^{1}$, Adam G. ${ }^{1}$, Cahill M.A. ${ }^{2}$, Sotlar K. ${ }^{3}$, Wallwiener D. ${ }^{1}$ Solomayer E. ${ }^{1}$, Fehm T. ${ }^{1}$ \\ ${ }^{1}$ University of Tübingen, Department of Obstetrics and Gynecology, Tübingen; ${ }^{2}$ ProteoSys AG, Mainz; ${ }^{3}$ University of Tübingen, Institute of Pathology, Tübingen}

Background: In contrast to intracellular steroid receptors, which mainly induce ligand-activated nuclear transcription, membrane-bound steroid receptors are hypothsized to account for the so-called "nongenomic" steroid hormone effects. The progesterone receptor membrane component 1 (PGRMC1) is a $28 \mathrm{kDa}$ transmembrane protein consisting of 194 amino acids which belongs to the "membrane-associated progesterone receptor" (MAPR) protein family.

Aim: The aim of this project is to characterize the potential biological function of PGRMC1 by structure analysis and generation of different mutant forms.

Material and Methods: Structure analysis was performed using the Scansite cell signaling interactions prediciton "MotifScan" module (http://scansite. mit.edu/motifscan_id.phtml) under high and medium stringency to identify protein motifs predicted for PGRMC1. Based on these predicted motifs PGRMC1-variants were generated by site-directed mutagenesis and MCF-7 breast cancer cells were stably transfected with the corresponding expression plasmids. Functional tests were performed by stimulating transfected $\mathrm{MCF}-7$ cells with a membrane-impermeable pro-gesterone:BSA:fluoresceinisothiocyanate conjugate followed by analysis of cell proliferation through measuring the cellular ATP content. Additionally, a potential function of PGRMC1 in oxidative stress response was investigated by treating MCF-7 transfectants with hydrogen peroxide.

Results: Structure analysis revealed that PGRMC1 contains a cytochrome b5 domain and several protein interaction domains making it a possible signalling adaptor protein. Stimulation of PGRMC1 expressing MCF-7 cells with progesterone:BSA:fluoresceinisothiocyanate conjugate resulted in an approx. $40 \%$ increased proliferation compared to control cells grown in growth factor and hormone reduced medium. Treatment of stable transfectants with hydrogen peroxide reduced sensitivity of one transfectant expressing mutant PGRMC1 compared to MCF-7 cells transfected with wildtype PGRMC1.

Conclusion: Functionally PGRMC1 might play a role in cell proliferation and stress response. Further determination of the so far poorly defined role of
PGRMC1 in cancer biology could prove to be of great relevance to clinical cancer therapists.

\section{PE527}

\section{Down-regulation of SIBLING proteins and their transcription factor Runx2 by RNAi leads to reduced migration of breast cancer cells in vitro}

\author{
Reufsteck C. ${ }^{1}$, Kübler D. ${ }^{2}$, Berger M. ${ }^{1}$ \\ ${ }^{1}$ DKFZ, G401, Heidelberg; ${ }^{2}$ DKFZ, A060, Heidelberg
}

Mammary carcinomas are frequently associated with osteolytic bone metastases that impair patients' lives by causing severe pain and fractures. One possibility of interfering with bone metastasis consists in targeting osteopontin (OPN) and bone sialoprotein (BSP) as members of the SIBLING (small integrin-binding ligand $\mathrm{N}$-linked glycoprotein) family and their transcription factor Runx2. OPN and BSP were reported to be elevated in the serum of patients with breast cancer bone metastasis, which also correlates with poor survival. Similary, Runx 2 was found to be upregulated in metastatic breast cancer cells. This study reports on the down-regulation of OPN, BSP and Runx 2 by RNAi in the human breast adenocarcinoma cell line MDA-MB-231 and its impact on the migratory behaviour.For each target, several siRNAs were delivered into MDA-MB-231 cells and tested for their efficiency in decreasing the respective mRNA and protein levels. Compared to control cells that were transfected with a non-functional siRNA, the OPN mRNA amount could be diminished by 98 percent, and we were able to obtain a reduction of BSP and Runx2 protein by 60 and 92 percent, respectively. The individual siRNA provoking this down-regulation was selected for migration studies using a modified Boyden chamber assay. Osteosarcoma (Saos-2) cell conditioned medium in the lower compartment was used as an attractant for siRNA-transfected, GFPmarked MDA-MB-231 cells, which were placed in a porous membrane insert above. After $24 \mathrm{~h}$, migrated cells were counted by flow cytometry. It was found that cells transfected with siRNAs against OPN, BSP and their transcription factor Runx 2 all show a significant reduction in their ability to migrate, which was decreased by 70, 80 and 50 percent, respectively, in comparison to control cells. The results here indicate that down-regulation of the selected proteins as shown particularly for OPN and BSP attenuates breast cancer cells' migratory abilities, and thus these targets are promising for further investigations of their potential in treatment of breast cancer bone metastasis.

\section{PE528}

\section{Activated Leukocyte Cell Adhesion Molecule (ALCAM/CD166): Positive correlation with bone metastasis and possible predictive value in patients treated for primary breast cancer}

Ihnen M. ${ }^{1}$, Müller V. ${ }^{1}$, Wirtz R.M. ${ }^{2}$, Schroeder C. ${ }^{3}$, Witzel I. ${ }^{1}$, Krenkel S. ${ }^{3}$, Lisboa B. ${ }^{1}$, Milde-Langosch $\mathrm{K}^{3}$

${ }^{1}$ UKE Hamburg, Frauenklinik, Hamburg; ${ }^{2}$ Siemens Medical Solutions Diagnostics $\mathrm{GmbH}$, Leverkusen; ${ }^{3}$ UKE Hamburg, Gynäkologische Forschung, Hamburg

Backgrund: Activated Leukocyte Cell Adhesion Molecule (ALCAM/CD166) is a cell surface immunoglobulin expressed in normal and neoplastic tissues and is assumed to be implicated in tumorigenesis and tumour progression. However, conflicting results for the role of ALCAM expression in breast cancer were reported. In our present study we evaluated protein and mRNA expression levels of ALCAM in breast cancer tissue in correlation to histological parameters and disease outcome in patients treated with Taxane-free adjuvant chemotherapy.

Methods: Western Blot analysis of ALCAM expression in tumour tissue extracts from 162 primary breast cancer patients (median follow-up time: 84,0 months) was performed. The results were analysed in relation to clinical and histological data including disease free und overall survival. To validate our results obtained at protein level, ALCAM mRNA expression was also evaluated by microarray analysis (Affimetrix HG U133A).

Results: Western Blot analysis showed a significant positive correlation of high ALCAM protein expression with positive estrogen receptor status $(\mathrm{p}=0.040)$. In patients with relapse, the appearance of bone metastasis was 
correlated with high ALCAM levels, whereas the presence of visceral metastasis was associated with low ALCAM expression $(\mathrm{p}=0.010)$. Other parameters like type of histology, stage, nodal involvement, age or grading did not correlate with ALCAM expression.

ALCAM mRNA expression correlated strongly with ALCAM protein levels $(\mathrm{p}<0.001)$. Interestingly, there was an improved disease free (DFS) and overall survival (OS) in patients treated with adjuvant chemotherapy expressing high/moderate ALCAM protein or mRNA levels compared to those with low ALCAM expression. These differences were highly significant for DFS and OS in mRNA analysis (HR 0,40 p =0,0083 and HR 0,27 p =0,0003 respectively).

Conclusion: There is a clear correlation of protein and mRNA expression of ALCAM in breast cancer tissue. The results of our study indicate for the first time that ALCAM might be a useful predictive indicator of resistance of adjuvant Taxane-free chemotherapy. We explored that high ALCAM expression showed a positive correlation with bone metastasis. These findings could provide insights into the metastatic process in primary breast cancer.

\section{PE529}

\section{Unexpected remission of MDA-MB-231 mammary carcinoma cells deposited into the skeleton of nude rats upon withdrawal of intensified carbohydrate feeding}

\author{
Hahn M. ${ }^{1}$, Zepp M. ${ }^{1}$, Reufsteck C. ${ }^{1}$, Schönig K. ${ }^{2}$, Löw R. ${ }^{3}$, \\ Bäuerle T. ${ }^{4}$, Berger S. ${ }^{2}$, Bartsch D. ${ }^{2}$, Berger $M .{ }^{1}$ \\ ${ }^{1} \mathrm{DKFZ}$, G401, Heidelberg; ${ }^{2}$ Zentralinstitut für Seelische Gesundheit, \\ Mannheim; ${ }^{3}$ EUFETS AG, Idar Oberstein; ${ }^{4}$ DKFZ, E020, Heidelberg
}

Breast cancer is one of the most frequent human cancers and often disseminates into the skeletal system. Following diagnosis of breast cancer skeletal metastasis, the available treatment options are mainly palliative. Therefore, it is a promising attempt to develop models of skeletal metastasis which mimic the human situation and can be used for the evaluation of new treatment options.

To facilitate the detection of cancer in vivo, MDA-MB-231 cells were transduced with a luciferase gene under the control of the Tet-off-system. This cell line was checked for its osteotropism in nude rats. To that purpose, cells were injected into the right femoral artery, thereby restricting osteolysis to one leg. Luciferase signals were quantified every second day, using a luciferase-camera (IVIS-system). For testing the function of the Tet-system, groups of four rats received doxycycline (dox) via the drinking water at concentrations of $0.5 \mu \mathrm{g} / \mathrm{ml}, 2 \mu \mathrm{g} / \mathrm{ml}$ and $10 \mu \mathrm{g} / \mathrm{ml}(0.25 \mathrm{mg} / \mathrm{kg}, 1 \mathrm{mg} / \mathrm{kg}$ and $5 \mathrm{mg} / \mathrm{kg})$, respectively. To facilitate consumption, $5 \%$ saccharose was added to the doxycycline- containing drinking water. Immediately after injection of MDA-MB-231 cells into the femoral artery, these cells were detected only in the respective leg by intensive luciferase signalling. Administration of dox via the saccharose containing drinking water effectively switched off the luciferase-signal. Later, dox and saccharose were discontinued so that the light signal was detected again. This showed, that the Tet system functioned as expected. However, the signal disappeared after a short period of time. In addition, no osteolytic lesions were detected by CT-analysis after a time interval that was sufficiently long to conclude that no tumor lesions had been developed. We hypothesize that this unexpected remission was due to the cessation of intensified saccharose feeding. It is likely that elevated levels of insulin were produced by the rats in response to the sugar consumption. This, in turn, might have caused an enhanced sensitivity of MDA-MB-231 cells to insulin as a growth factor, e.g. by over-expression of the insulin receptor. If this consideration proved true, the observed remission could be interpreted as a rebound remission due to the normalization of insulin levels in response to the end of the intensified saccharose feeding. Future experiments with diagnostic purposes will concentrate on avoiding this effect.

\section{PE530}

Patients' imagination of therapy efficacy and correlation to the willingness to accept chemotherapy and endocrine therapy of breast cancer -results of the gut informieren Gemeinsam entscheiden!-study

Lux M.P. ${ }^{1}$, Radosavac D. ${ }^{1}$, Tänzer T.D. ${ }^{1}$, Kara H. ${ }^{1}$, Bani M.R. ${ }^{1}$, Schrauder M. ${ }^{1}$, Schmitt D.C. ${ }^{2}$, Haidinger R. ${ }^{3}$, OverbeckSchulte B. ${ }^{4}$, Schulte H. ${ }^{4}$, Beckmann M.W. ${ }^{1}$, Fasching P.A. ${ }^{1}$

${ }^{1}$ Universitätsklinikum Erlangen, Universitäts-Brustzentrum Franken (UBF), Erlangen; ${ }^{2}$ Mamazone e.V., Augsburg; ${ }^{3}$ Brustkrebs Deutschland e.V., München; ${ }^{4}$ Frauenselbsthilfe nach Krebs e.V., Bundesverband, Bonn

Introduction: Possible treatment options for patients with breast cancer (BC) present different ratios of risk and benefit. Patient orientated therapy decision requires knowledge and education of these ratios. Several factors can influence the individual perception about the demanded benefit of chemotherapy and endocrine therapy. The knowledge about the factors can support an individual and conjoint therapy decision. This study investigated the influencing factors on the patient's willingness to accept chemotherapy and endocrine therapy with special regard to the demanded therapy benefit.

Material and Methods: A total of 8.485 questionnaires were distributed to patients with BC with the support of Frauenselbsthilfe nach Krebs e.V., mamazone e.V., Brustkrebs Deutschland e.V., further patient support groups and numerous breast centres. Online participation was also possible. Patients were asked about personal information, medical history, experienced side effects and the personal perception of a necessary benefit by different treatment options on the basis of curative and palliative case studies.

Results: 2.065 patients have answered the questionnaire (return 24.34\%). 90 patients have participated online. With a postulated 5 year overall survival (OS) of $60 \%$ without any therapy most of the patients $(44.7 \%)$ demanded an absolute improvement of $>10 \%$ to decide for a chemotherapy (ctx). $39.8 \%$ of the patients demanded an improvement of $>10 \%$ to decide for an endocrine treatment (etx). Factors that influence the demanded improvement of OS were marital status $(\mathrm{p}[\mathrm{ctx}]=0.004 / \mathrm{p}[\mathrm{etx}]=0.063)$, educational degree $(\mathrm{p}[\mathrm{ctx}]<0.001 /$ $\mathrm{p}[\mathrm{etx}]<0.001)$, occupational status $(\mathrm{p}[\mathrm{ctx}]<0.001 / \mathrm{p}[\mathrm{etx}]<0.001)$, family size $(\mathrm{p}[\mathrm{ctx}]<0.001 / \mathrm{p}[\mathrm{etx}]<0.001)$, contact to patient's advocacy groups $(\mathrm{p}[\mathrm{ctx}]<0.001 / \mathrm{p}[\mathrm{etx}]<0.001)$ and age of the patient $(\mathrm{p}[\mathrm{ctx}]<0.001 /$ $\mathrm{p}[\mathrm{etx}]<0.001)$, age of the youngest child $(\mathrm{p}[\mathrm{ctx}]<0.001 / \mathrm{p}[\mathrm{etx}]<0.001)$.

Conclusion: Most of the patients demand a benefit which lies above the really expected therapy effect, for both chemotherapy and endocrine therapy. Several socio-economic factors have a major influence on the demanded benefit. Education and familial status seem to alter the perception of risk and seem to influence the willingness to accept chemotherapy and endocrine treatment. As patient education and information has a known influence on quality of life these effects have to be taken into consideration when informing the patient about the therapy.

\section{PE531}

\section{Doctors' imagination of therapy efficacy and correlation} to the willingness to indicate chemotherapy and endocrine therapy in breast cancer patients-results of the gut informieren - Gemeinsam entscheiden!-study

Lux M.P. ${ }^{1}$, Tänzer T.D. ${ }^{1}$, Radosavac D. ${ }^{1}$, Kara H. ${ }^{1}$, Bani M.R. ${ }^{1}$ Kreis H. ${ }^{1}$, Beckmann K. ${ }^{1}$, Schmitt D.C. ${ }^{2}$, Haidinger R. ${ }^{3}$, OverbeckSchulte B. ${ }^{4}$, Schulte H. ${ }^{4}$, Beckmann M.W. ${ }^{1}$, Fasching P.A. ${ }^{1}$

${ }^{1}$ Universitätsklinikum Erlangen, Universitäts-Brustzentrum Franken (UBF), Erlangen; ${ }^{2}$ Mamazone e.V., Augsburg; ${ }^{3}$ Brustkrebs Deutschland e.V., München; ${ }^{4}$ Frauenselbsthilfe nach Krebs e.V., Bundesverband, Bonn

Introduction: Guidelines are available giving recommendations for the curative and palliative treatment of patients with breast cancer (BC). However, personal the physicians' personal background influences therapy decisions. The knowledge about individual influencing factors could help to optimize professional education and therapy decisions. This study investigated personal influencing factors like the demanded therapy efficacy and the educational status on the willingness to indicate chemotherapy or endocrine treatment. Material and Methods: 6.938 questionnaires were distributed to oncologists. They were asked about personal information, work environment, study 
participation, oncological speciality and treated patient characteristics. Demanded therapy efficacy was assessed by fictitious BC cases and proposed therapies with specific benefits.

Results: 470 physicians have answered the questionnaire (response rate $6.8 \%$ ). 55 physicians have participated online. $95.4 \%$ were gynecologists. $72.3 \%$ had an oncological speciality while $88.3 \%$ worked in the oncological field more than 5 years. Physicians treated in average 7.4 patients with primary BC, 2.8 metastasized patients and 7.0 patients in surveillance a week. Most of the physicians (56.5\%) demanded an improvement of overall survival (OS) of $5-10 \%$ for a patient with postulated a 5 -year OS probability of $60 \%$ without any therapy to decide for chemotherapy. Only $13.5 \%$ would decide for chemotherapy based on an improvement of OS of $1-4 \%$. Concerning endocrine therapy $32.8 \%$ considered $1-4 \%$ improvement of OS enough to indicate it. A factor that had a consistent influence on the demanded benefit was, if the physicians administer chemotherapies theirselves. Physicians who administer chemotherapy personally demanded a lower benefit of the chemotherapy than colleagues who do not $(\mathrm{p}=0.001)$. Younger physicians were more easily satisfied with a lower improvement of OS by chemotherapy $(\mathrm{p}=0.011)$ or endocrine treatment $(\mathrm{p}=0.001)$.

Conclusion: Physicians' demands for an improvement of survival to decide for or against a chemotherapy and endocrine therapy meet the published data. However, there are some influencing factors that might bias the decision for or against chemotherapy, independently of the patient risk group. Physicians' individual perception of the therapy effect might influence the therapy decision independently of defined risk groups and therapy guidelines.

\section{PE532}

\section{Breast cancer patients and theirs doctors differ in the demand for the magnitude of the therapy effect of chemotherapy and endocrine treatment-results of the gut informieren - Gemeinsam entscheiden!-study}

Lux M.P. ${ }^{1}$, Radosavac D. ${ }^{1}$, Kara H. ${ }^{1}$, Tänzer T.D. ${ }^{1}$, Löhberg C.R. ${ }^{1}$, Schmitt D.C. ${ }^{2}$, Haidinger R. ${ }^{3}$, Overbeck-Schulte $B .{ }^{4}$, Schulte $H_{.}{ }^{4}$, Müller U. ${ }^{1}$, Beckmann M.W. ${ }^{1}$, Fasching P.A. ${ }^{1}$

${ }^{1}$ Universitätsklinikum Erlangen, Universitäts-Brustzentrum Franken (UBF), Erlangen; ${ }^{2}$ Mamazone e.V., Augsburg; ${ }^{3}$ Brustkrebs Deutschland e.V., München; ${ }^{4}$ Frauenselbsthilfe nach Krebs e.V., Bundesverband, Bonn

Introduction: Patients with breast cancer (BC) are often feel not well informed about the risk-benefit ratio of an anticancer therapy. Physicians have their own measures for assessing this ratio as well. Literature presents remarkable differences between the demanded efficacy of a treatment option by patients and their physicians. Individual conjoint therapy decision needs detailed knowledge about the different perceptions. This study investigated the differences of patient's and physician's willingness to choose chemotherapy and endocrine therapy regarding the demanded therapy benefit.

Material and Methods: 6.938 questionnaires were distributed to oncologists and 8.485 were sent to BC patients with the support of Frauenselbsthilfe nach Krebs e.V., mamazone e.V., Brustkrebs Deutschland e.V., further patient support groups and numerous breast centres. Online participation was also possible. The same 26 fictitious $\mathrm{BC}$ cases in the curative setting with different 5 year survival rates $(60 \%$ and $80 \%)$ and palliative situation were presented to both collectives. Demanded benefits with regards to overall survival (OS) in order to be willing to perform chemotherapy or endocrine therapy were asked. Results: A total of 2.065 patients und 470 physicians completed the questionnaire (response rates $24.34 \%$ and 6.8\%). 90 patients and 55 physicians participated online. Patients' and physicians' demands for an improvement of OS were different for both the cases with the good and the less favourite prognosis $(\mathrm{p}<0.001)$. For the patient with a postulated OS of $60 \%$ more than $64 \%$ of the patients demanded an improvement of OS of more than $10 \%$ whereas only $30 \%$ of the physicians did need the same improvement of OS to indicate chemotherapy. With regard to endocrine therapy this effect was even larger. Of the patients $57.7 \%$ wished a therapy effect of larger than $10 \%$ whereas only $17.5 \%$ of the physicians demanded this large therapy effect.

Conclusion: The patients' and the physicians' of demanded therapy effects differ substantially. Physicians were more likely to be satisfied with a smaller therapy effect whereas the patients demanded mostly an absolute improvement of OS larger than $10 \%$. A large variety of influencing factors has to be taken into consideration to explain this effect. There needs to be an urgent necessity to improve the perception of patient and physician for each other. This would help to provide a basis for a conjoint therapy decision process.

\section{PE533}

Effect of zoledronate on persisting isolated tumor cells in bone marrow of breast cancer patients during recurrencefree follow-up

Rack B. ${ }^{1}$, Jückstock J. ${ }^{1}$, Genss E.-M. ${ }^{1}$, Schoberth A. ${ }^{2}$, Schindlbeck C. ${ }^{1}$, Strobl B. ${ }^{1}$, Heinrigs M. ${ }^{1}$, Rammel G. ${ }^{1}$, Zwingers $T^{3}{ }^{3}$, Sommer $H .{ }^{1}$, Friese $K{ }^{1}{ }^{1}$, Janni $W{ }^{1}$

${ }^{1}$ Ludwig-Maximilians-Universität, I. Frauenklinik, Klinikum Innenstadt, München; ${ }^{2}$ Labor Drs. Tiller und Partner, München; ${ }^{3}$ estimate $\mathrm{GmbH}$, Augsburg

Purpose: Isolated tumor cells (ITC) in bone marrow of breast cancer pts have recently been shown to have impact on survival both at primary diagnosis and during recurrence-free follow-up. The goal of the present study is to investigate the therapeutic efficacy of zoledronate on the persistence of ITC in the bone marrow of breast cancer pts after completion of primary therapy.

Method: We followed 172 breast cancer pts without evidence for distant recurrence but detection of ITC in bone marrow. As part of an interventional pilot study, zoledronate was applied at $4 \mathrm{mg} \mathrm{q} 4 \mathrm{wx} 6 \mathrm{mon}$ (loading dose $8 \mathrm{mg}$ ) to $31 \mathrm{pts}$ who had completed surgery, leading to R0 resection of their tumor, and adjuvant chemotherapy for at least 6 months. In a matched pair analysis, these pts were compared to those $141 \mathrm{pts}$, who were treated according to standard guidelines but did not receive additional zoledronate treatment. The bone marrow was re-examined after a median of 7.9 months (std .89) in the treatment group and 11.5 months (std 12.41; $\mathrm{P}=.11$ ) in the control group. ITC were detected by immunocytochemical staining using the monoclonal pan-cytokeratin antibody A45-B/B3 and the APAAP technique. Pts were followed prospectively for a median of 39 months following the first aspiration. Results: Primary tumor characteristics, i.e. tumor size $(\mathrm{P}=.09)$, axillary nodal status $(\mathrm{P}=.85)$, hormone receptor status $(\mathrm{P}=.67)$ and grading $(\mathrm{P}=.35)$, as well as surgical $(\mathrm{P}=.22)$, adjuvant systemic $(\mathrm{P}=.18)$ and irradiation treatment $(\mathrm{P}=.51)$ were well balanced between both pt groups. While ITC were detected in all 172 pts at the time of first bone marrow aspiration, four pts (13\%) showed ITC following 6 months of zoledronate therapy. In contrast, persisting ITC were detected in 38 pts $(27 \%)$ of the control group without zoledronate treatment $(\mathrm{P}=.099)$. The reduction in cell numbers between first and second aspiration reached statistical significance in the zoledronate group $(\mathrm{P}=.02)$ in contrast to control pts $(\mathrm{P}=.14)$. Persistent ITC at the follow-up aspiration were associated with reduced RFS $(\mathrm{P}=.05)$. Among $12 \mathrm{pts}$ without detection of ITC in bone marrow after treatment who underwent additional aspirations, 10 pts showed a persistently negative bone marrow status after a median of 19 months (range 4.7-38.7 mon) following treatment. Zoledronate treatment was well tolerated with mild bone pain as the most common side effect in $45 \%$ of pts $(n=14)$.

Conclusion: These results indicate a potential antineoplastic effect of the cell-cycle independent agent zoledronate on persisting ITC in dormant state. Our data provide a hypothesis generating basis to investigate the therapeutic efficacy of zoledronate on ITC in the secondary adjuvant setting by prospectively randomized trials.

\section{PE534}

The BCRM (Breast Cancer Matching Tool)-preliminary results and perspectives for clinical routine

Kansy B., Wallwiener M., Brucker S., Wallwiener C., Kansy K. Universitätsfrauenklinik, Tübingen

Background: As recruitment rates for patients enrolled into clinical trials still contrasts with the number of patients potentially willing to join clinical trials, integrating more standardised computer-based screening for trial participation into clinical routine seems to be one consequent attempt to increase recruitment rates. One of the key components of the web-based senological portal www.brustkrebs-studien.de is a standardised trial recruitment tool (BCRM). Previous investigations analysed the feasability of this tool on a web-based level for patients. In this study we investigate the feasability of integrating BCRM into clinical routine. 
Objectives: In this study we aimed to analyse clinical workflows for trial recruitment and data management to set up a prototype of the BCRM integrated in clinical information systems (CIS) and to test the feasability of using it in clinical routine.

Material and Methods: Firstly, all physicians involved in the clinical trial recruiment process were interrogated and the recruitment workflow was evaluated and analysed for potential data interfaces with the BCRM. Data used for trial recruitment in the weekly clinical oncology interdisciplinary conference was compared to the BCRM data set. A secure data transfer was established and corresponding data was imported into the BCRM. This prototype was then tested in a retrospective analysis: Recruitment on 22 patients that had been recruited for the SUCCESS trial in 2006 and 2007 in the weekly tumor board was compared to recruitment via BCRM.

Results: 184 points of documentation are available via clinical information systems (CIS) of which 36 are relevant for the BCRM data set. Imported CIS data was $100 \%$ correct when used for the BCRM clinical prototype. On retrospective analysis 21 out of 22 patients (95\%) previously recruited for the SUCCESS trial were also identified as potential SUCCESS trial patients by the BCRM prototype. Conclusions: The integration of BCRM into preexisting clinical information systems is feasable. The BCRM clinical prototype has shown to provide correct and reliable results for breast cancer trial recruitment on retrospective analysis. Outlook: As a next step, we are conducting a prospective trial using the BCRM prototype in real time and comparing results with trial recruitment via the weekly clinical oncology interdisciplinary conference. We are documenting both trial suggestions and actual enrollment. In the future, the BCRM can be extended to other oncological trial subgroups.

\section{PE535}

\section{Presence of impaired T-cell activation in the bone marrow and peripheral blood of primary breast cancer with tumor cell dissemination?}

Gruber I., Landenberger N., El Yousfi S., Dürr-Störzer S., Wallwiener D., Solomayer E., Fehm T.

Universität, Frauenklinik, Tübingen

Introduction: Detection of micrometastatic bone marrow cells at diagnosis has been recently identified as an independent prognostic factor of primary breast cancer. It still remains unclear, why these disseminated tumor cells are able to survive in the bone marrow and peripheral blood over years and are not eradicated by the local immune system.
Methods and Results: Recently we could show that patients with primary beast cancer have an impaired T-cell activation of peripheral blood lymphocytes. Compared to healthy donors breast cancer patients have a highly significant reduction of CD 28 , the important molecule for effective T-cell priming. Moreover we found a concomitant highly significant downregulation of TCR zeta on cytotoxic and T-helper cells, which determines the functional integrity of specific immune response by phosphorylation. These results are connected with Fas-induced apoptosis of peripheral blood lymphocytes.

Based on these findings we now investigate the activation status of T-cells in the bone marrow and peripheral blood, comparing breast cancer patients with tumor cell disseminated ( TCD-pos) and patients without tumor cell dissemination ( TCD-neg ). The T-cell activation status is analysed by multicolour flow cytometry and results are correlated with clinic- pathological prognostic factors by Mann-Whitney Wilcoxon U-test.

Conclusion: Findings of T-cell impairment would explain the broken concept of immune surveillance by resting disseminated tumor cells. This might give the opportunity for later reactivation of breast cancer disease although primary tumor was eradicated by surgery and adjuvant therapy.

\section{PE536} Tumor cell detection in bone marrow: Clinical follow-up of
breast cancer patients with primary metastatic disease

Sonnauer M. ${ }^{1}$, Kaul S. ${ }^{1}$, Deckert A. ${ }^{2}$, Zeifang $F^{3}{ }^{3}$, Fersis $N .{ }^{1}$

${ }^{1}$ Universität, Frauenklinik, Heidelberg; ${ }^{2}$ University, Inst. for medical biometry and informatics, Heidelberg; ${ }^{3}$ Universität, Orthopädie, Heidelberg

Background: Bone marrow samples from 2050 patients operated for primary breast cancer (stage T1-4, N0/N+, M0/M1) at the University Hospital Heidelberg between 1999 und 2005 were analysed for disseminated tumor cells (DTC) on cytospin slides. In this report we present follow-up results of patients with primary metastatic disease evaluating weather DTC detection affects prognosis and overall survival among this group of patients.

Material and Methods: Mononuclear cells were enriched by Ficoll densitygradient centrifugation. Cytospin-slides (mean 6) with $1 \times 10^{6} \mathrm{BM}$-cells (area $240 \mathrm{~mm}^{2}$ ) were stained with $\mathrm{CK}$ antibodies 5D3, A45-B/B3, or AE1+AE3 using automated immunostainers (Dako Techmate 500 and Ventana NEXES) with the APAAP- and the enhanced SA-FastRed-method. Positive controls were routinely prepared by adding 50 tumor cells to $1 \times 10^{6} \mathrm{BM}$-cells either from clinical samples or from normal bone marrow donors. Slides were analysed by automated picture analysis with the ACIS I and ACIS II systems

Fig. 1. Disease free survival in BM-negative and BM-positive patients with metastatic primary breast cancer (for Abstract PE536)
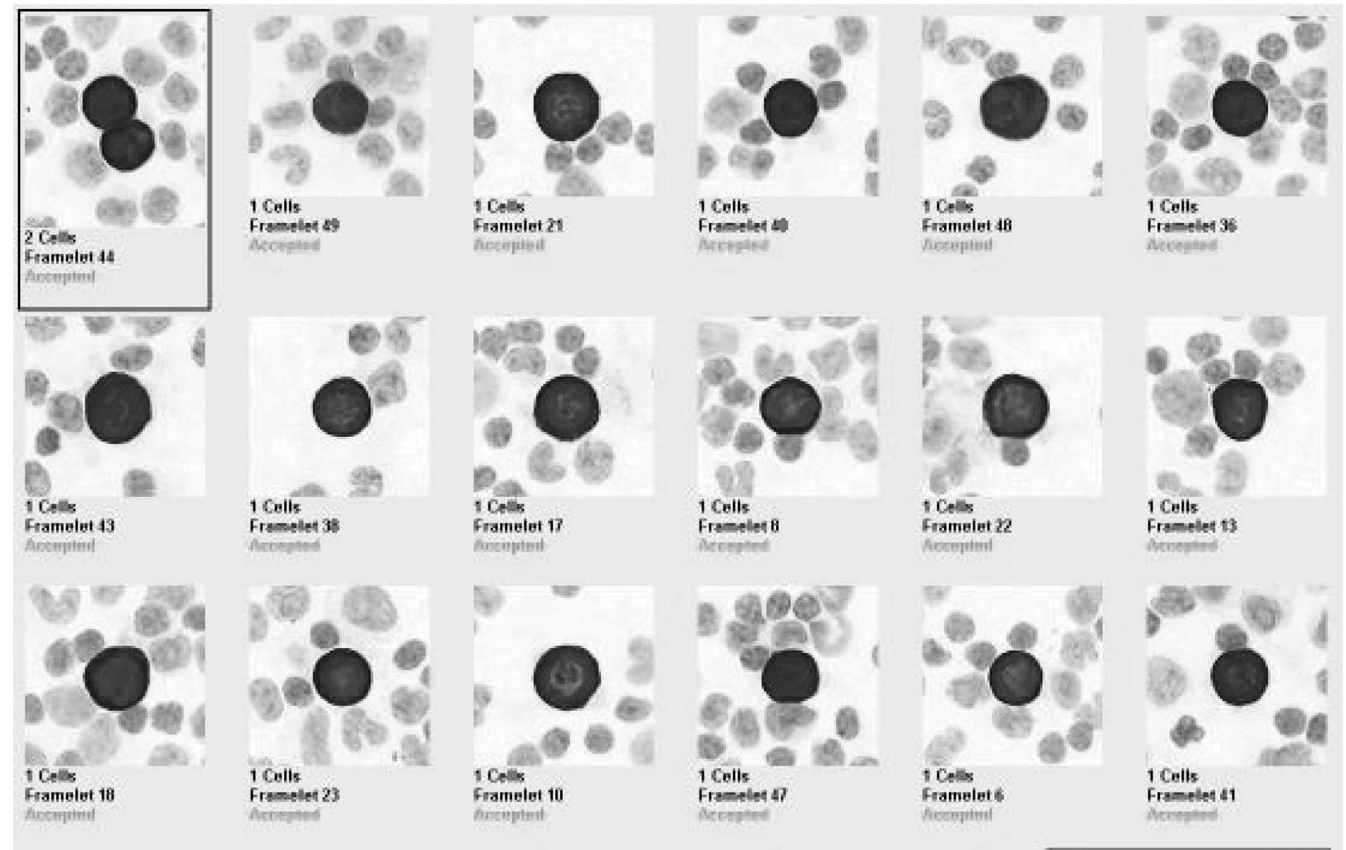
(ChromVision). Criteria for classification of disseminated tumor cells were in compliance with the publication of Fehm et al. (Cancer, Vol.107, 2006).

Results: Cytokeratin-positive tumor cells were characterized by a mean area value of 309 (area $=$ cell size x staining intensitiy), by strong and irregular cytoplasmic cytokeratin staining, a granular nucleus and a clearly enlarged nuclear size according to the ACIS picture analysis. Using these tumor classification critera 13 from 31 (41.9\%) patients with primary metastatic breast carcinoma were scored DTC positive. The detection rate ranged from 5 to 6667 cells (mean 1407). Notable is the fact that 11/13 BM-positive patients developed clinically proofed metastases compared to only $9 / 18$ patients in the DTCnegative group. During the observation period, 7 patients with bone metastases and positive BM status died from metastatic breast cancer while only 2 patients with negative DTC detection results died from metastatic disease. Discussion: In contrast to the low detection rate of 1.3\% (26/2017) in patients with stage $\mathrm{T} 1-4, \mathrm{~N} 0 / \mathrm{N}+, \mathrm{M} 0$ breast carcinomas, patients with primary metastatic disease were the only subgroup which was significantly associated with higher rates in DTC positivity. The documented follow-up shows that positive BM status correlates with shorter disease-free and overall survival because more than two third of these patients died within five years after primary diagnosis of breast cancer (mean 2.2 years).

\section{PE537}

\section{Embedded Tumor Cell Calibrators (ETC) for normalized quantitative multi-gene expression analysis of micrometastatic cells in blood and bone marrow of cancer patients}

\section{Koliogiannis $D .{ }^{1}$, Fersis $N .{ }^{1}$, Zeifang $F^{2}{ }^{2}$, Sonnauer M. ${ }^{1}$, Kaul S. ${ }^{1}$}

${ }^{1}$ Universität , Frauenklinik, Heidelberg; ${ }^{2}$ Universität, Orthopädie, Heidelberg

Background: Immunomagnetic tumor cell enrichment combined with realtime reverse transcription polymerase chain reaction (RT-PCR) offers high sensitivity for detection of tumor-associated mRNA. Methods widely used for quantification of low abundance mRNA depends on the expression ratio of a target gene versus one or several non-regulated housekeeping genes. However, this approach is inadequate for rare cell analysis because tumor cells constitue only a small minority $\left(1\right.$ in $\left.10^{3}-10^{4}\right)$ in purified blood or bone marrow samples. We report here a new technique called embedded tumor cell calibrators (ETC) for tumor cell quantification and gene expression analysis.

Material and Methods: Bone marrow and blood samples from normal donors and patients with breast carcinoma were devided in at least one native probe and several matched calibrator probes. Calibrator probes were spiked with either 2, 4,8 or 16 breast carcinoma cells (embedded tumor cell calibrators, ETC) under microscopic control. Native and matched ETC samples were processed side by side under identical conditions through the following steps: a) immunomagnetic tumor cell enrichment using the high affinity antibodies BM7 (MUC-1) and VU1D9 (EpCAM), b) m-RNA isolation, c) c-DNA-synthesis

Fig. 1. ETC: test validation and sensitivity in bone marrow samples based on CK11 expression. Calibrator HD-ZE breast carcinoma cell line.

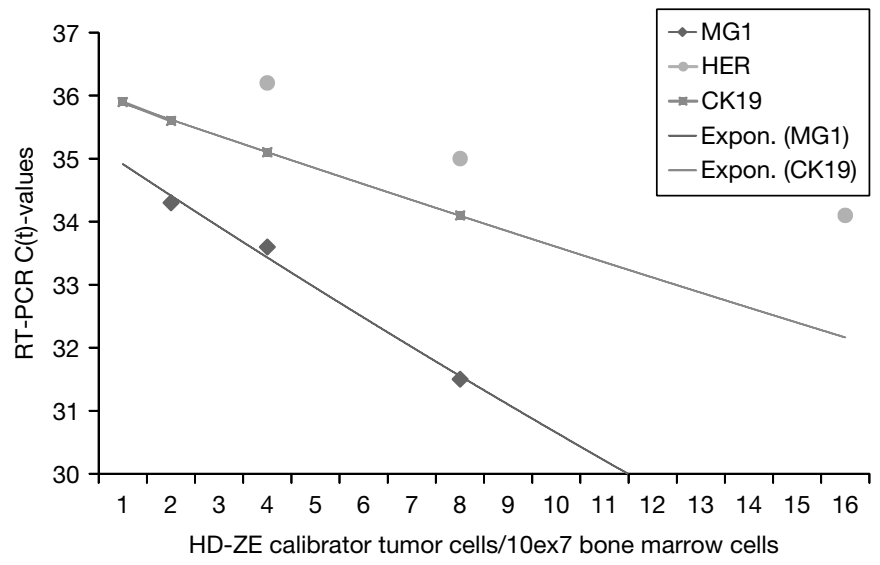

d) real-time RT-PCR using primers and FAM-labeled TaqMan probes selected with the UniversalProbeLibrary system (Roche AG, Basel, CH).

Results: The new diagnostic tool was established with cytokeratin 19 (CK19) and Mammaglobin 1 (MG1) as tumor cell quantifiers and HER-2 and CD276 as modell targets for gene expression analysis. Using $5 \mathrm{ml}$ whole blood (106 samples) and Ficoll separated bone marrow (72 samples, $1 \times 10^{7}$ cells) we have established and validated conditions for tumor cell quantification in the range of 1 to 16 tumor cells (Fig 1). In 25 native probes tumor cells were successfully quantified (mean 2.5 cells) and corresponding HER2 and CD276 expression ratios were normalized to the calibrator cells HD-ZE.

Discussion: We have designed a new technical approach which allowed simultaneous tumor cell quantification and relative gene expression analysis of rare tumor cells in bone marrow and blood. Within the range of one to ten tumor cell in $5 \mathrm{ml}$ blood or $1 \times 10^{7}$ bone marrow therapeutically relevant tumorassociated markers like HER2 and the tumor-specific angiogenesis factor CD267 could be accurately quantified. The technique can be adopted to other carcinoma types and further surrogate markers.

\section{PE538}

\section{Evaluation of the correlation between bone density and tumour cell dissemination in primary breast cancer patients}

\author{
Krämer B., Solomayer E., Wallwiener D., Fehm T. \\ Universitaet, Frauenklinik, Tuebingen
}

Introduction: Osteoporosis is associated with an impaired bone microenvironment and bone turnover characterised by a mismatch between osteoblast and osteoclast activity with higher osteoclastic activity. In bone metastases, growth factors secreted by osteoclasts activate tumour cells. Therefore, it was hypothezied that breast cancer patients with osteoporosis are more likely to develop metastatic bone disease (Altundag et al. 2006) since the increased activity of osteoclasts may facilitate tumor cell dissemination in the bone marrow. Therefore, we investigated the question of whether a lower bone mass favours dissemination of tumour cells in the bone marrow.

Methods: A total of 210 women (age 31 to 84), (95 pre- and perimenopausal, 115 postmenopausal) with primary breast cancer underwent quantitative ultrasonometry (QUS) of the heel before adjuvant chemotherapy. Pre-operatively, each patient underwent bone marrow aspiration from the right or left iliac crest. Tumour cells were detected by immunohistochemistry using CK-antibody.

Results: The median T-score in the pre-/perimenopausal group was -0.37 (minimum: -2.73 , maximum: 2.70 ) and in the postmenopausal group -1.38 ( $\min -5.19, \max 1.56)$. Interestingly, the T-score was correlated with the size of the tumor. The median T-score for patients with T1-tumours was -0.675 , for T2-tumours -1.269 and for T3/4-tumours -2.047 in the whole group $(\mathrm{P}<0.05)$. No correlation was found between bone mass and tumour cell dissemination in the bone marrow for both groups $(\mathrm{P}>0.05)$.

Conclusion:

1. Breast cancer patients at the time of first diagnosis have normal bone density. 2. No correlation was found between bone mass and tumour cell dissemination. 3. Despite these negative results, it is an interesting fact that disseminated tumor cells can be eliminated by bisphosphonates which are used to treat osteoporosis by inhibiting osteoclasts.

\section{PE539 \\ Improvement of communication skills of oncologists in explaining therapy options and clinical trials to cancer patients training concept and preliminary results}

\section{Wünsch A., Gölz T., Bertz H., Fritzsche K. Universitätsklinikum Freiburg, Freiburg}

Background: Physicians in oncology are obliged to inform patients about clinical trials in accordance to ethical and legal standards. Based on this information, the patient has to come to a decision whether to participate in a clinical trial. Physicians are, however, inadequately prepared for this task.

Objectives: Can a specific training for oncologists improve the conveying of key information about clinical trials (main objective)? Can this specific training increase the physicians' feeling of competence (objective 2) and the 
understanding of the concept of Informed Consent of the actor-patient (objective 3)?

Methods: Physicians are randomly assigned to an intervention or a waiting control group. The intervention consists of a manualized training on conveying key information about therapy options and clinical trials. Training success is evaluated by comparison of 2 video-recorded consultations with actorpatients before and after training. Likewise, questionnaires are used to rate the physicians' feeling of competence and the understanding of Informed Consents by standardized patients.

Results: The training and evaluation concept as well as preliminary results are presented.

\begin{tabular}{l}
\hline Breast Cancer (Surgery and Radiotherapy) \\
\hline Oral Presentations \\
\hline
\end{tabular}

OP175

Verlauf und Prognose nach operativer Therapie von

Patienten mit skelettärer Metastasierung bei Mammakarzinom

\section{Dürr H.R. ${ }^{1}$, Weis C. ${ }^{1}$, Glaser C. ${ }^{2}$, Jansson V. ${ }^{3}$}

${ }^{1}$ Klinikum der LMU München, Standort Großhadern, Schwerpunkt Tumororthopädie,Orthopädische Klinik, München; ${ }^{2}$ Klinikum der LMU München, Standort Großhadern, Institut für Radiologie, München; ${ }^{3}$ Klinikum der LMU München, Standort Großhadern, Orthopädische Klinik, München

Fragestellung: Aufgrund längerer Überlebenszeiten wird häufig die skelettale Metastasierung zum die Lebensqualität bestimmenden Faktor bei Patienten mit Karzinomen. Es konnte gezeigt werden, daß die Wahl des therapeutischen Vorgehens und die Prognose der Patienten dabei vom Primärtumor abhängig ist. Gerade Patientinnen mit Mammakarzinom zeigen oft lange Verläufe, die in der Wahl des operativen Vorgehens berücksichtigt werden müssen. Zu klären ist die Frage, ob eine potentiell "kurative“ Resektion mit eventuell höherer Morbiditiät als das rein palliative Vorgehen, prognostische Vorteile zeigt.

Material und Methoden: Im Zeitraum 1980-2006 wurden 113 Patienten mit Knochenmetastasen eines Mammakarzinoms operativ versorgt. Bei den 110 Frauen und 3 Männern betrug das Durchschnittsalter bei der Operation 57,5 Jahre (31-84 Jahre). Dokumentiert wurden Lokalisation und Ausdehnung, Klinik, operatives Verfahren, Metastasierungsstatus, Komplikationen, Rezidive und Überlebenszeit.

Ergebnisse: Insgesamt wurden 145 Eingriffe durchgeführt. Eine Dekompression oder Stabilisierung der Wirbelsäule war dabei mit 56 Fällen der häufigste Eingriff. Das proximale Femur mußte in 24 Fällen endoprothetisch versorgt werden, eine endoprothetische Versorgung des prox. Humerus erfolgte in zwei, des Beckens in einen Fall. Eine diaphysäre Prothese wurde implantiert. Zwei Resektionen erfolgten ohne Rekonstruktion. In 24 Fällen wurde eine

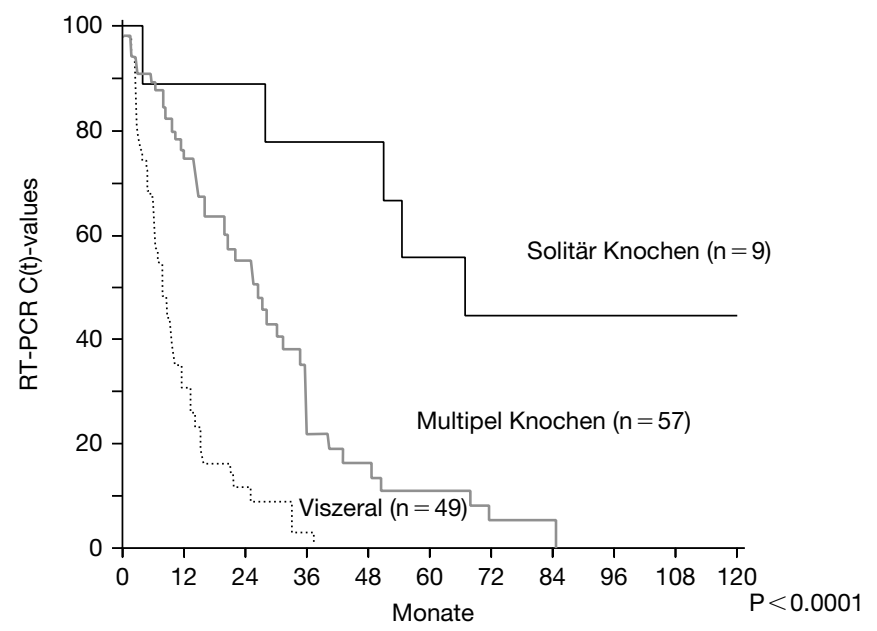

Verbundosteosynthese, in 20 Fällen nur eine Biopsie durchgeführt. In der Regel schloß sich der Operation eine Nachbestrahlung an oder wurde in einigen Fällen auch präoperativ durchgeführt. Die Nachuntersuchung fand zwischen 1 und 20 Jahren nach dem Eingriff statt (Durchschnitt 5 Jahre).Lokalrezidive traten in 4 Fällen auf. Die 30-Tage Letalität lag bei 5,6\%. Erfreulicherweise zeigte sich trotz zwar ausgedehnter Metastasierung eine oft ausgesprochen lange Überlebenszeit der Patientinnen mit zum Teil vergleichsweise geringer Einschränkung des Allgemeinbefindens. Die mediane Überlebenszeit betrug dabei 25 Monate. 28 Patienten zeigten schon beginnend eine viszerale Metastasierung, 47 waren diffus ossär metastasiert, in 23 Fällen fand sich lediglich ein solitärer Knochenherd. Die Überlebenszeit zwischen viszeral oder diffus ossär metastasierten Patienten unterschied sich signifikant (siehe Abb.). Die radikale Resektion, wie sie anfänglich in einigen Fällen versucht wurde, konnte keinen Überlebensvorteil zeigen bei erneuten Auftreten weiterer Herde im Verlauf.

Schlussfolgerung: Patienten mit Knochenmetastasen bei Mammakarzinom haben eine vergleichsweise gute Prognose mit zum Teil trotz ausgedehntester Metastasierung langen Verläufen. Das intraläsionale Vorgehen mit additiver Radiatio ist dabei funktionell den radikaleren Ansätzen überlegen, ohne daß dies zu einem Nachteil im Gesamtüberleben führt.

\section{OP176 \\ Boost in breast cancer as infield boost - A practicable possibility at irradiation with "sliding window" and "COMART"?}

Buth K.-J., Oehler W., Wagner K.

Südharz-Krankenhaus, Strahlentherapie, Nordhausen

Background: Radiation treatment of breast after breast conserving surgery of cancer is obligate. Total dose (TD) of 50,0 Gy ( $50,4 \mathrm{~Gy}$ ) is treated with 2,0 Gy $(1,8 \mathrm{~Gy})$ per fraction, with an consecutive boost to the primary size with an TD 10,0 Gy (16,0 Gy), with 2,0 Gy per fraction. A higher biological $e$ ffectiveness from boost treatment is possible by higher dose per fraction, but with a higher risk of side effects for lung, skin and heart. If the boost is integrated in the basic radiation, a dose not higher then 2,15 Gy per fraction is necessary for 60,40 Gy TD in the tumor volume.

Method: For the integration of the boost treatment in the basic radiation series at the application of COMART (Conformal-MLC-arc), will be two fields more used then the standard radiation fields of COMART.

The radiation treatment with sliding window doesn't need more fields. Both methods show dose distributions with 50,4 Gy for breast with 1,8 Gy per fraction and 60,2 Gy for tumor (boost volume) with 2,15 Gy per fraction. It will be shown examples for each technique.

Results: The biological effectiveness for tumor volume is higher because the dose will be given in 28 fractions instead of 33 fractions and the risk of side effects for lung, skin and heart is the same as the basic radiation with connected boost radiation. This will be shown in dose distribution of the radiation techniques. Consequently are unfavorable late reactions not to be expected. Conclusion: Integration of the boost treatment in basic radiation series can improves the biological effectiveness for tumor volume. At the same time the side effects for organ at risk are the same as for the connected radiation. Cosmetically results will be prospectally note in our institution. But unfavorable late reactions are not to expect, because of the only low higher dose per fraction.

\section{OP177}

Intensity-Modulated Radiotherapy (IMRT) of breast cancer protects the organs at risk: Data from 205 patients

Huhnt W., Sidow D., Buchali A.

Ruppiner Kliniken $\mathrm{GmbH}$, Klinik für Strahlentherapie und Radioonkologie, Neuruppin

Purpose: To assess the toxicity and dose distribution of Intensity-modulated Radiotherapy (IMRT) in breast cancer patients.

Patients and Methods: Between 08/2005 and 08/2007, 205 women suffering from breast cancer were treated with IMRT and analysed retrospectively. Most patients $(\mathrm{n}=198,97 \%)$ suffered from unilateral disease, 7 patients $(3 \%)$ had 
bilateral breast carcinoma. All patients received irradiation of the breast or thoracic wall of $50 \mathrm{~Gy}$ using single doses of $2 \mathrm{~Gy}$. Depending on risk factors, a boost of $16 \mathrm{~Gy}$ was applied to the initial tumor region in $38 \%$ of the patients. Regional lymph nodes (LN) were treated with 50 Gy (axillary LN: $22 \%$ of the patients, supraclavicular LN: 73\%, internal mammary LN: 59\%). In case of macroscopic residual disease a boost of $10-16$ Gy was applied to the $\mathrm{LN}$ $(\mathrm{n}=7,3 \%)$. IMRT was performed with median 4 (4-12) photon beams using sliding-window technique. Acute toxicity and dose distribution in the organs at risk were analysed. Statistics: mean $\pm \mathrm{SD}$, t-test.

Results: In unilateral breast cancer, dose-volume-histograms of the entire lung showed a V20Gy of $13,0 \pm 3,7 \%$, a V30Gy of $8,5 \pm 2,6 \%$ and a mean lung dose of $10,1 \pm 2,0 \mathrm{~Gy}$. In bilateral disease we found a V20Gy of $23,4 \pm 8,1 \%$, a V $30 \mathrm{~Gy}$ of $12,2 \pm 4,4 \%$ and a mean lung dose of $14,4 \pm 4,2$ Gy. In patients with left-sided breast cancer doses of the heart were 19,3 $\pm 4,9$ Gy (D33\%), 15,7 \pm 4,8 Gy (D50\%) and 17,3 $\pm 4,7$ Gy (mean dose) if internal mammary $\mathrm{LN}$ were treated, whereas without irradiation of internal mammary LN a D33\% of $16,9 \pm 4,8$ Gy $(\mathrm{p}<0,05)$, a D50\% of $12,9 \pm 4,3$ Gy $(p<0,05)$ and mean dose of $14,9 \pm 4,2$ Gy $(p<0,05)$ were calculated. IMRT was performed according to treatment plan in all patients and was very well tolerated. None of the patients developed a symptomatic pneumonitis. Skin toxicities were erythema (grade 1: $62,1 \%$, grade $2: 20,4 \%$ ), superficial epitheliolysis $(22,8 \%$ ) and hyperpigmentation (grade $1: 23,8 \%$, grade $2: 1,5 \%$ ). Transient esophagitis occurred in 27,7\% (grade 1) and 1,9\% (grade 2).

Conclusion: IMRT of breast cancer is safe and feasible in clinical routine. IMRT allows to protect the organs at risk, as low doses are found in lung and heart, even in left-sided or bilateral disease. In addition, the irradiation of internal mammary lymph nodes can easily be performed using IMRT. The treatment resulted in low toxicity in both skin and esophagus.

\section{OP178}

\section{A randomised trial comparing shoulder-arm-morbidity in patients with sentinel node biopsy and complete axillary dissection}

\author{
Helms G. ${ }^{1}$, Kuehn T. ${ }^{2}$, Moser L. ${ }^{3}$, Remmel E. ${ }^{4}$, Wallwiener D. ${ }^{1}$, \\ Kreienberg $R^{5}$
}

${ }^{1}$ Universitätsfrauenklinik, Tuebingen; ${ }^{2}$ Städtisches Krankenhaus,

Frauenklinik, Esslingen; ${ }^{3}$ Universitäts-Hals-Nasen-Ohrenklinik, Wuerzburg; ${ }^{4}$ Evangelisches Krankenhaus, Institut für Plastische Chirurgie, Hattingen; ${ }^{5}$ Universitätsfrauenklinik, Ulm

Background: Axillary lymph node dissection (ALNE) as part of surgical treatment in breast cancer has been the standard. However, patients frequently develop shoulder-arm-morbidity postoperatively. Recently, sentinel node (SN) biopsy has been established as a new standard of care for axillary staging in breast cancer. This study compares postoperative morbidity between ALNE and SN. The results are compared with the existing literature.

Method: Between November 2000 and September 2002, 181 women with early-stage breast cancer underwent primary surgery following preoperative randomisation into two groups, a "standard group" (SN biopsy was followed by ALNE) and a study group (surgical procedure consisting of only SN biopsy when histologically metastasis-free $\mathrm{SN}$ was present).

Follow-up data (362 sessions; 3 months to 3 years after primary surgery) were available from 150 patients. A summary morbidity score was calculated from four subjective (arm-strength, arm-mobility, arm swelling, pain) and four objective (arm-strength, arm-mobility, lymphedema, sensitivity) criteria.

Results: Fifty seven patients underwent SN biopsy only. Ninety three patients underwent ALNE, 57 of which had lymph nodes free of metastasis and 36 had lymph nodes with metastasis and axillary clearing. Shoulder-arm morbidity was significantly different between the groups. Patients treated with SN biopsy only scored better on subjective and objective criteria. These findings indicated that SN biopsy only may result in less severe shoulder-arm morbidity.

Summary: Post surgical shoulder-arm morbidity is a major long-term problem in patients undergoing surgical treatment for breast cancer. This randomised study showed significantly less severe shoulder-arm morbidity following SN biopsy compared to patients undergoing ALNE.

\section{OP179}

Outcome of prophylactic mastectomies in women of breast cancer families with and without BRCA1/2 mutations

\section{Rhiem K., Flucke U., Bosse K., Wappenschmidt B., Warm M.,} Schmutzler $R$.

Universitätsklinikum, Frauenklinik, Köln

Background: $B R C A 1 / 2$ germline mutation carriers have an up to $80 \%$ lifetime risk to suffer from breast cancer. In $43 \%$ of women with BRCA1- and in $35 \%$ of women with BRCA2-associated breast cancer a contralateral carcinoma will be diagnosed. Bilateral prophylactic mastectomy (BPM) reduced the risk for breast cancer by approximately $95 \%$. The purposes of our investigation are 1. to determine the prevalence of (pre-)maligne lesions in prophylactic mastectomy specimen of women at high risk with and without $B R C A$ mutations and 2. to specify the sensitivity of breast imaging techniques prior to the prophylactic mastectomy.

Patients and Methods: In our Centre of Familial Breast and Ovarian Cancer Cologne we identified 284 mutation carriers (174 BRCA1, 113 BRCA2) and 332 women with high-risk for breast cancer from 1997 to 2007. One-hundredeighty-six BRCA mutation carrier (114 BRCA1, 72 BRCA2) and 284 women at high risk without a $B R C A$ mutation took part in the structured surveillance programme consisting of annual mammography (MG), magnet resonance imaging (MRI) and biannual ultrasound of the breast (US).

Results: Overall 52 women underwent a prophylactic mastectomy, 20 BRCA1 mutation carriers, 12 BRCA2 mutation carriers and $20 B R C A 1 / 2$ negative high risk women. Fourty-one women underwent a contralateral prophylactic mastectomy (CPM) after breast cancer diagnosis while eleven women were healthy and decided to have a BPM. We detected a ductal carcinoma-in situ (DCIS) in $3(6 \%)$ of the prophylactically removed breasts. None of the DCIS was diagnosed in US (0/3), MG (0/3) or MRI (0/2).

Conclusion: We detected a $6 \%$ prevalence of DCIS in women with an autosomal dominant family history for breast cancer tested positive or negative for a BRCA mutation. These high-risk intraepithelial lesions have not been diagnosed within the structured surveillance programme. These data demonstrate that new biomarkers and imaging techniques are needed for the detection of intraepithelial lesions. These results may be relevant for breast cancer prevention in these patients. The risk reducing effect of BPM has been demonstrated for healthy high risk women so far. Further investigations should reassess the effect of CPM.

\section{Breast Cancer (Systematic and Supportive Therapy)}

Oral Presentation

OP165

Oblimersen $(O)$ in combination with docetaxel $(T)$, adriamycin (A), and cyclophosphamide (C) as Neoadjuvant Systemic Therapy (NST) in Primary Breast Cancer (PBC): Final results of a multicentric phase I study

Rom J. ${ }^{1}$, Schlehe B. ${ }^{1}$, Marmè F. ${ }^{1}$, Schuetz F. ${ }^{1}$, Buechele $T .^{2}$ Sinn H.-P. ${ }^{3}$, von Minckwitz G. ${ }^{4}$, Sohn $C .{ }^{1}$, Schneeweiß A. ${ }^{1}$

${ }^{1}$ Universität, Gynäkologie \& Geburtshilfe, Heidelberg; ${ }^{2}$ Aventis Pharma $\mathrm{GmbH}$, Bad Soden; ${ }^{3}$ Universität, Institut für Pathologie, Heidelberg; ${ }^{4}$ German Breast Group, Neu Isenburg

Backround: The Bcl-2 downregulator $\mathrm{O}$ in combination with standard cytotoxic chemotherapy leads to synergistic antitumor effects in preclinical trials. To evaluate maximum tolerated dose (MTD), safety and preliminary efficacy of $\mathrm{O}$ in combination with TAC as NST in PBC we performed a multicentric phase I study.

Methods: Previously untreated patients with PBC T2-4a-c N0-3 M0 received escalating doses of $\mathrm{O}$ as a 24 hour continuous infusion on day (d) 1-7 in combination with $\mathrm{T} 75 \mathrm{mg} / \mathrm{m}^{2}$, A $50 \mathrm{mg} / \mathrm{m}^{2}$ and C $500 \mathrm{mg} / \mathrm{m}^{2}$ on day 5 followed by five three weekly cycles of TAC without $\mathrm{O}$.

Results: A total of twenty-eight patients with a median age of 50 years were enrolled. $61 \%$ of tumors were T2, $43 \%$ grade 3, $68 \%$ ductal-invasive, and $64 \%$ hormone receptor positive. Patients received $\mathrm{O}$ in a dose of $3 \mathrm{mg} / \mathrm{kg} / \mathrm{d}$ (cohort I, 9 patients), $5 \mathrm{mg} / \mathrm{kg} / \mathrm{d}$ (II, 9 patients), and $7 \mathrm{mg} / \mathrm{kg} / \mathrm{d}$ (III, 10 patients), 
respectively. No dose-limiting toxicity occurred. Most common adverse events [all National Cancer Institute-Common Toxicity Criteria (NCI-CTC) grade $\leq 2]$ were fatigue, nausea, alopecia, headache and flue-like symptoms observed in $78 \%$ (I), $89 \%$ (II), and $90 \%$ (III) of patients, respectively. Following OTAC the most severe hematological toxicity was neutropenia (NCI-CTC grade 1-2/3/4) which developed in $0 / 0 / 56 \%$ of patients (I), $11 / 0 / 56 \%$ of patients (II), and 20/20/50\% of patients (III), respectively. At least $50 \%$ reduction in tumor volume was oberved in 14 patients. Five patients (18\%) achieved a pathologic complete response (3 patients in cohort I, 2 patients in cohort II).

Conclusion: $O$ up to a dose of $7 \mathrm{mg} / \mathrm{kg} / \mathrm{d}$ given as a 24 hour infusion on day $1-7$ can be safely administered in combination with standard TAC on day 5 as NST in patients with PBC. The preliminary efficacy warrants further evaluation of this combination in a randomised trial

\section{OP166}

A multicentre phase I dose finding study to investigate the combination of bendamustine with weekly paclitaxel as first or second line therapy in patients with anthracycline pretreated metastatic breast cancer - The RiTa trial

Loibl S. ${ }^{1,2}$, Murmann C. ${ }^{2}$, Schwedler K. ${ }^{2}$, Warm M. ${ }^{3}$, Müller L. ${ }^{4}$, Heinrich G. ${ }^{5}$, Nekljudova V. ${ }^{1}$, von Minckwitz G. ${ }^{1,2}$

${ }^{1} \mathrm{GBG}$ Forschungs $\mathrm{GmbH}$, Neu-Isenburg; ${ }^{2}$ Uniklinikum, Frauenklinik, Frankfurt a.M.; ${ }^{3}$ Uniklinikum Köln, Frauenklinik, Köln; ${ }^{4}$ Onkologische Schwerpunktpraxis, Leer; ${ }^{5}$ Onkologische Schwerpunktpraxis, Fürstenwalde

Background: The aim of the RiTa trial is to establish a feasible combination of bendamustine and paclitaxel in a weekly schedule in anthracycline pretreated metastatic breast cancer patients.

Methods: The RiTa trial is a prospective multicentre phase I dose finding study. The starting dose of bendamustine was $50 \mathrm{mg} / \mathrm{m}^{2}$ and was stepwise increased by $10 \mathrm{mg} / \mathrm{m}^{2}$ up to $70 \mathrm{mg} / \mathrm{m}^{2}$. The starting dose of paclitaxel was 60 $\mathrm{mg} / \mathrm{m}^{2}$ and was increased up to $90 \mathrm{mg} / \mathrm{m}^{2}$. There are five dose levels with 3 patients per dose level (maximum 6 patients) and 6 patients in the last doselevel (Goodman et al.). Dose limiting toxicities were severe neutropenia and thrombocytopenia as well as non-haematological toxicities $>=$ NCI-CTC grade 3 (except emesis and alopecia) in the $1^{\text {st }}$ cycle.

Results: Between September 2005 and February 2007, 18 patients (pts) had been enrolled, the median age was 62 years (range 38-72). 83.3\% of all pts had liver metastases, $55.6 \%$ bone metastases, and $22.2 \%$ lung metastases. No dose limiting toxicity up to $70 \mathrm{mg} / \mathrm{m}^{2}$ bendamustine and $90 \mathrm{mg} / \mathrm{m}^{2}$ paclitaxel occurred during the 1st cycle. Over all cycles the following severe haematological toxicities (grade 3 and 4) were documented: neutropenia 5 pts (1 pt dose-level 1, 2 pts dose-level 3,1 pt dose-level 4, 1 pt dose-level 5) and anaemia $1 \mathrm{pt}$ in dose-level 2. Relevant grade 3 and 4 non-haematological toxicities over all cycles were fatigue $2 \mathrm{pts}$ ( $1 \mathrm{pt}$ in dose-level 1 and 2$)$, dyspnoea $1 \mathrm{pt}$ in dose-level 5, infection $4 \mathrm{pts}$ (1pt in dose-level 3 and $3 \mathrm{pts}$ in dose-level 5 ) and bone pain $1 \mathrm{pt}$ in dose-level 2. Five serious adverse events ( 2 fatigue, 1 anaemia, 1 allergic reaction, 1 dehydration), but no death occurred. So far one complete response and 3 partial remissions were observed.

Conclusion: The treatment with weekly bendamustine and paclitaxel is an effective and feasible regimen in patients with metastatic and anthracycline pretreated breast cancer. The determined dose for the phase II trial, which will start shortly, will be $70 \mathrm{mg} / \mathrm{m}^{2}$ bendamustine and $90 \mathrm{mg} / \mathrm{m}^{2}$ paclitaxel.

\section{OP167}

Dose-intensified epirubicin versus standard-dose epirubicin/cyclophosphamide followed by CMF in breast cancer patients with 10 or more positive lymph nodes: Results of a randomized trial (GABG-IV E-93)

Vescia S. ${ }^{1,2}$, Eiermann W. ${ }^{3}$, Graf E. ${ }^{4}$, Raab G. ${ }^{5}$, Conrad B. ${ }^{6}$, Hilfrich $\mathrm{J}^{7}$, Massinger-Biebl $\mathrm{H}^{8}$, von Minckwitz G. ${ }^{1,9}$, Schumacher M. ${ }^{4}$, Kaufmann M. ${ }^{9}$

${ }^{1} \mathrm{GBG}$ Forschungs $\mathrm{GmbH}$, Neu-Isenburg; ${ }^{2} \mathrm{Städt}$. Klinikum Hanau, Frauenklinik, Hanau; ${ }^{3}$ Frauenklinik vom Roten Kreuz München, München ${ }^{4}$ Medizinische Biometrie und Statistik, Freiburg; ${ }^{5} \mathrm{G}$ näkologische Praxis, München; ${ }^{6}$ Elisabeth-Krankenhaus, Frauenklinik, Kassel; ${ }^{7}$ Henriettenstiftung, Frauenklinik, Hannover; ${ }^{8} \mathrm{Gynäkologische} \mathrm{Gemeinschaftspraxis,}$ Waldkirchen; 9 J. W. Goethe Universität, Frauenklinik, Frankfurt a.M.

Background: In 1993 the German Adjuvant Breast Cancer Group (GABG) started a series of trials for various risk groups. The GABG-IV E study compared dose-intensified epirubicin (E120) versus standard-dose epirubicin/ cyclophosphamide (EC) followed by cyclophosphamide/ methotrexate/5-fluorouracil (CMF) in high risk breast cancer patients with 10 or more positive lymph nodes. Here the results of this study at five years' median follow-up are presented.

Methods: Between March 1993 and December 2000411 patients with primary breast cancer and $>=10$ involved axillary nodes were randomised to four 21-day cycles of epirubicin $120 \mathrm{mg} / \mathrm{m}^{2}(\mathrm{n}=202)$ or to four 21-day cycles of EC $\left(90 \mathrm{mg} / \mathrm{m}^{2} / 600 \mathrm{mg} / \mathrm{m}^{2}\right)$, followed by three 28 -day cycles of CMF (500 $\left.\mathrm{mg} / \mathrm{m}^{2} / 40 \mathrm{mg} / \mathrm{m}^{2} / 600 \mathrm{mg} / \mathrm{m}^{2}\right)(\mathrm{n}=209)$. Simultaneous hormonal treatment was applied in both arms.

Results: At 5 years' median follow-up, five-year event-free survival (EFS) rates were $47.7 \%$ (95\% confidence interval [CI], $40.2 \%$ to $55.2 \%$ ) for E120 and $45.9 \%$ (38.5\% to 53.3\%) for EC-CMF. E120 was as effective as EC-CMF for EFS (hazard ratio [HR] for E120 versus EC-CMF 1.04; 95\% CI, 0.79 to $1.36 ; \mathrm{p}=0.79$ ) and with regard to overall survival (HR 1.06; $95 \%$ CI 0.77 to $1.46 ; p=0.72$ ).

Conclusion: The data provide no evidence that dose-intensified epirubicin improved the prognosis of breast cancer patients with more than 10 positive lymph nodes.

\section{OP168}

\section{Expression of Estrogen Receptor (ER) in disseminated} tumor cells of breast cancer patients

\section{Krawczyk N., Banys M., Wallwiener D., Solomayer E.-F., Fehm T.} Universitaets-Frauenklinik Tuebingen, Tuebingen

Background: The presence of disseminated tumor cells (DTC) in bone marrow (BM) of primary breast cancer patients is associated with poor prognosis These patients may benefit from adjuvant endocrine therapy since cytotoxic agents are not able to eliminate DTCs completely as previously shown. The $\mathrm{ER} \alpha$ status is routinely defined in primary tumor tissue and only patients with hormone receptor positive breast cancer are eligible for hormonal treatment. However, the ER $\alpha$ status of DTC may differ compared to the primary tumor. Therefore, the aims of this study were (1) to determine the ER $\alpha$ status of DTC in BM of breast cancer patients, (2) and to compare the ER $\alpha$ status of DTC and corresponding primary tumors.

Methods: BM aspirates from 275 primary breast cancer patients were included into the study. A double immunofluorescence staining procedure was established for the identification of cytokeratin-positive (CK) / ER $\alpha$ positive cells. ER $\alpha$ status of the primary tumor was immunohistochemically assessed using the same antibody against $\mathrm{ER} \alpha$.

Results: In 113 of 275 (41\%) breast cancer patients CK-positive cells could be detected in BM. The number of detected cells ranged between 1 and 55 / cells per $2 * 10^{6}$ mononuclear cells. Disseminated tumor cells demonstrated ER $\alpha$ positivity in 15 (13\%) of these 113 patients. The ER $\alpha$ expression on DTC was heterogeneous in 12 of $15(80 \%)$ patients. Concordance rate of ER $\alpha$ status between primary tumor and DTC was 26\%. Only 13 of 94 patients with ER $\alpha$ positive tumors had also ER $\alpha$ positive DTC.

Conclusions:

(1) The hormone receptor status between primary tumor and corresponding DTC may differ. 
(2) This discrepancy may explain the rate of non-responders to adjuvant endocrine therapy despite ER-positive primary tumor.

(3) These patients may benefit from adjuvant therapy regimens based on antibody strategies or bisphosphonates.

\section{OP169}

Final toxicity analysis of the adebar phase III study evaluating the role of docetaxel in the adjuvant therapy of breast cancer patients with extensive lymph node involvement

Janni W. ${ }^{1}$, Harbeck $N{ }^{2,3}$, Sommer H. ${ }^{1}$, Rack B. ${ }^{1}$, Augustin $D .^{3}$, Simon $W^{4,5}$, Wischnik A. ${ }^{5}$, Annecke $K^{2}{ }^{2}$, Friese $K^{1}{ }^{1}$, Kiechle M. $^{2}$

${ }^{1}$ LMU, FK INN, München; ${ }^{2} \mathrm{TU}, \mathrm{FK}$, München; ${ }^{3}$ Mammazentrum,

Ostbayern, Deggendorf; ${ }^{4} \mathrm{FK}$, Robert-Bosch-KH, Stuttgart; ${ }^{5}$ Frauenklinik,

Zentralklinikum, Augsburg

Background: Taxane based adjuvant chemotherapy has been established as standard treatment in node-positive breast cancer. However, toxicity concerns

\begin{tabular}{|c|c|c|c|c|c|}
\hline $\begin{array}{l}\text { Tax. Event } \\
\text { (NCI-grades } \\
3 \text { or } 4\end{array}$ & Group & $\begin{array}{l}\text { EC-DOC } \\
(\%)\end{array}$ & $\begin{array}{l}\text { FEC } \\
(\%)\end{array}$ & $\begin{array}{l}\text { Rel. risk } \\
\text { EC-Doc/ } \\
\text { FEC }\end{array}$ & $\begin{array}{l}\text { p-value } \\
\text { (Chi- } \\
\text { square } \\
\text { test) }\end{array}$ \\
\hline \multicolumn{6}{|c|}{ Hematologic Toxicity } \\
\hline \multirow[t]{3}{*}{ Neutropena } & all & 59.2 & 61.1 & 0.90 & 0.49 \\
\hline & Cycle 1-3 & 52.5 & 68.4 & 0.91 & 0.27 \\
\hline & Cycle 4-6 & 57.9 & 58.0 & 0.99 & 1.0 \\
\hline \multirow[t]{3}{*}{ Anemia } & all & 2.7 & 15.4 & 0.18 & $<0.001$ \\
\hline & Cycle 1-3 & 7.9 & 16.6 & 0.47 & 0.031 \\
\hline & Cycle 4-6 & 1.5 & 14.6 & 0.10 & $<0.001$ \\
\hline \multirow[t]{3}{*}{ Thrombocytopenia } & all & 2.0 & 23.9 & 0.08 & $<0.001$ \\
\hline & Cycle 1-3 & 7.2 & 18.0 & 0.40 & 0.009 \\
\hline & Cycle 4-6 & 0.6 & 25.3 & 0.02 & $<0.001$ \\
\hline \multirow[t]{3}{*}{ Leukopenia } & all & 72.0 & 79.8 & 0.90 & 0.001 \\
\hline & Cycle 1-3 & 55.8 & 81.6 & 0.68 & $<0.001$ \\
\hline & Cycle 4-6 & 76.9 & 79.2 & 0.97 & 0.43 \\
\hline \multirow[t]{3}{*}{ Infections } & all & 9.4 & 15.5 & 0.61 & 0.001 \\
\hline & Cycle 1-3 & 15.3 & 29.2 & 0.52 & 0.004 \\
\hline & Cycle 4-6 & 7.8 & 9.6 & 0.82 & 0.35 \\
\hline \multicolumn{6}{|c|}{ Non-Hematologic Toxicity } \\
\hline \multirow[t]{3}{*}{ Nausea } & all & 5.1 & 4.6 & 1.11 & 0.70 \\
\hline & Cycle 1-3 & 6.4 & 8.5 & 0.75 & 0.39 \\
\hline & Cycle 4-6 & 3.8 & 2.8 & 1.37 & 0.52 \\
\hline \multirow[t]{3}{*}{ Vomiting } & all & 6.2 & 2.8 & 2.22 & 0.003 \\
\hline & Cycle 1-3 & 12.9 & 5.6 & 2.32 & 0.014 \\
\hline & Cycle 4-6 & 1.5 & 1.9 & 0.82 & 0.79 \\
\hline \multirow[t]{3}{*}{ Mucosilis } & all & 8.9 & 8.6 & 1.03 & 0.92 \\
\hline & Cycle 1-3 & 6.0 & 10.8 & 0.55 & 0.16 \\
\hline & Cycle 4-6 & 9.6 & 7.8 & 1.24 & 0.36 \\
\hline \multirow[t]{3}{*}{ Edema } & all & 2.6 & 0.3 & 8.29 & 0.0007 \\
\hline & Cycle 1-3 & 4.6 & 2.3 & 1.97 & 0.65 \\
\hline & Cycle 4-6 & 2.4 & 0 & - & 0.0001 \\
\hline \multirow[t]{3}{*}{ Skin } & all & 4.2 & 0.8 & 5.46 & 0.0001 \\
\hline & Cycle 1-3 & 1.3 & 2.6 & 0.49 & 0.65 \\
\hline & Cycle 4-6 & 4.6 & 0.4 & 12.25 & $<0.0001$ \\
\hline \multirow[t]{3}{*}{ Diarrhoea } & all & 2.7 & 2.3 & 1.17 & 0.75 \\
\hline & Cycle 1-3 & 0.0 & 8.1 & - & 0.0061 \\
\hline & Cycle 4-6 & 3.1 & 0.9 & 3.26 & 0.0183 \\
\hline
\end{tabular}

of combined anthracycline-taxane regimens have compromised its acceptance. We analyzed the toxicity of a sequential anthracycline-taxane chemotherapy compared to a conventional anthracycline regimen.

Patients and Methods: ADEBAR was a multicenter phase III trial $(\mathrm{n}=1502)$ to evaluate whether breast cancer $(\mathrm{BC})$ pts with $>3$ axillary lymph metastases benefit from a sequential anthracycline-docetaxel regimen (E90C-D: 4 cycles epirubicin [E] $90 \mathrm{mg} / \mathrm{m}^{2}$ plus cyclophosphamide [C] $600 \mathrm{mg} / \mathrm{m}^{2}$ q21 days followed by 4 cycles docetaxel [D] $100 \mathrm{mg} / \mathrm{m}^{2}$ q21 days) compared to dose-intensive anthracycline-containing polychemotherapy (FE120C: 6 cycles E $60 \mathrm{mg} / \mathrm{m}^{2}$ d $1+8,5$-FU $500 \mathrm{mg} / \mathrm{m}^{2} \mathrm{~d} 1+8$ and $\mathrm{C} 75 \mathrm{mg} / \mathrm{m}^{2} \mathrm{~d} 1-14$, q4 weeks). We present the final toxicity analysis.

Results: Complete toxicity data were available from 1,338 pts. Hematological and non-hematological toxicities NCI grade 3-4 are depicted below. Treatment was stopped prematurely in $3.7 \%$ of the pts in the E90C-D arm and in $8.0 \%$ in the FE120C arm due to toxicity $(\mathrm{p}=0.0009)$. Antibiotic treatment was given in $10.4 \%$ (E90C-D) vs. $19.7 \%$ (FE120C), G-CSF support in $39.2 \%$ vs $61.4 \%$ and erythropoietin stimulation in $8.7 \%$ vs. $20.0 \%$, respectively $(\mathrm{p}<0.0001)$. Hematologic and non-hematological grade 3-4 toxicities are summarized in the table. In summary, haematological toxicity (leucopenia, infection thrombocytopenia, anemia) was significantly greater in the FE120C-arm. Skin toxicity, edema and vomiting occurred significantly more often in pts treated with E90C-D.

Conclusion: Different toxicity profiles given, overall toxicity of a sequential anthracycline-taxane regimen is not necessarily greater than that of an adequately dosed anthracycline chemotherapy, which needed to be interrupted more frequently due to toxicity.

\section{Breast Cancer (Systemic and Supporting Therapy)} Poster Exhibition

\section{PE553}

Intraoperative Radiotherapy (IORT) as an option for patients with localized breast recurrences after previous externalbeam radiotherapy

\section{Kraus-Tiefenbacher U. ${ }^{1}$, Bauer L. ${ }^{2}$, Scheda A. ${ }^{1}$, Schäfer J. ${ }^{1}$, Steil V. ${ }^{1}$, Wenz F. ${ }^{1}$}

${ }^{1}$ Universität, Strahlentherapie, Mannheim; ${ }^{2}$ Krankenhaus, Gynäkologie und Geburtshilfe, Weinheim

Introduction: For patients suffering of recurrent breast cancer within the irradiated breast, generally mastectomy is recommended. The normal tissue tolerance does not permit a second full-dose course of radiotherapy to the entire breast after a second breast-conserving surgery (BCS). A novel option is to treat these patients with partial breast irradiation (PBI). This approach is based on the hypothesis that re-irradiation of a limited volume will be effective and result in an acceptable frequency of side effects. The following report presentfs a single center experience with intraoperative radiotherapy (IORT) during excision of recurrent breast cancer in the previously irradiated breast.

Methods: Between 4/02 and 11/06, 15 patients were treated for in-breast recurrences at a median of 10 years (3-25) after previous EBRT (10 recurrences in the initial tumor bed, 3 elsewhere in-breast failures, 2 invasive recurrences after previous DCIS). Additional 2 patients were selected for IORT with new primary breast cancer after previous partial breast EBRT for treatment of Hodgkin's disease. IORT with a single dose of $14.7-20 \mathrm{~Gy} 50 \mathrm{kV} \mathrm{X-}$ rays at the applicator surface was delivered with the Intrabeam ${ }^{\mathrm{TM}}$-device (Carl Zeiss, Oberkochen, Germany).

Results: After a median follow-up of 26 months (1-60), no local recurrence occurred. 14 out of 17 patients are alive and free of disease progression. Two patients are alive with distant metastases. One patient died 26 months after BCS/ IORT due to pulmonary metastases diagnosed 19 months after BCS/IORT. Acute toxicity after IORT was mild with no Grade 3/4 toxicities and cosmetic outcome showed excellent/good/fair results in 7/7/3 cases.

Conclusions: IORT for recurrent breast cancer using low energy X-rays is a valuable option for patients with recurrent breast cancer after previous radiotherapy. 
PE554

Postoperative Strahlentherapie beim DCIS: Standards und Perspektiven

Budach $W .{ }^{1}$, Dunst J. ${ }^{2}$, Feyer $P .^{3}$, Haase $W^{4}$, Harms $W .^{5}$, Sauer R. ${ }^{6}$, Sautter-Bihl M.-L. ${ }^{7}$, Sedlmayer F. ${ }^{8}$, Souchon $R^{9}{ }^{9}$, Wenz F.10

${ }^{1}$ Universität Düsseldorf, Düsseldorf; ${ }^{2}$ Universität zu Lübeck, Klinik für Strahlentherapie, Lübeck; ${ }^{3}$ Vivantes Klinikum, Berlin-Neukölln; ${ }^{4}$ DEGROAG, Karlsruhe; ${ }^{5}$ Krankenhaus, Basel; ${ }^{6}$ Universität Erlangen, Erlangen; ${ }^{7}$ Städtisches Klinikum, Karlsruhe; ${ }^{8}$ Universität Salzburg, Salzburg; ${ }^{9} \mathrm{AK}$ Hagen, Hagen; ${ }^{10}$ Universität Mannheim, Mannheim

Die postoperative Bestrahlung ist die Maßnahme zur Senkung des Risikos für invasive und nicht-invasive Rezidive bei der brusterhaltenden Therapie des DCIS. In prospektiven Studien konnte bisher keine Subgruppe identifiziert werden, die nicht von einer Radiotherapie profitiert. Prognose-Scores zur Bewertung des Rezidivrisikos und der Indikation zur Strahlentherapie wurden ausschließlich aus retrospektiven Daten ermittelt (z.B. Van-Nuys-Score) und konnten in prospektiven Studien nicht bestätigt werden.

Für die klinische Forschung in der Radioonkologie sind zurzeit zwei Fragen von besonderem Interesse, nämlich die Frage der Zielvolumenreduktion bei Subgruppen mit niedrigem Rückfallrisiko (sog. akzelerierte Teilbrustbestrahlung) und die Möglichkeit der umschriebenen Dosiserhöhung (Boost) für Patientinnen mit hohem Rückfallrisiko analog zum inavsiven Karzinom. Ein Konzept für eine geplante Boost-Studie der DEGRO-AG Mammakarzinom wird vorgestellt.

PE555

Desire for improved cosmetic results after breastconserving therapy and mastectomyin breast cancer patients

Bani M. ${ }^{1}$, Engel J. ${ }^{1}$, Lux M.P. ${ }^{1}$, Rauh $C .{ }^{1}$, Eder I. ${ }^{1}$, Bani H. ${ }^{1}$, Jud S. ${ }^{1}$, Breuel C. ${ }^{1}$, Bach A. ${ }^{2}$, Beckmann M.W. ${ }^{1}$, Fasching P.A.

${ }^{1}$ Universitätsklinikum Erlangen, Universitäts-Brusztzentrum Franken,

Erlangen; ${ }^{2}$ Universitätsklinikum Erlangen, Department of Surgery, Erlangen

Introduction: The cosmetic results after surgery for breast cancer may compromise the patient's sense of well-being. The aim of the present survey was to evaluate correlates for the patient's desire for surgical improvement of the cosmetic outcome after the primary operation. A cross-sectional study was carried out using a questionnaire.

Patients and Methods: A structured questionnaire to assess the degree of satisfaction with the cosmetic results after breast cancer surgery was given to patients who had undergone mastectomy and breast-conserving surgery (BCS). The patients were asked to provide demographic data and to assess their degree of satisfaction with the cosmetic results and the way in which they influenced their relationship with their partner and sexuality. Characteristics were identified that were associated with the desire for surgical improvement of the cosmetic appearance.

Results: The response rate for the questionnaire was $85.8 \%(\mathrm{n}=964) ; 684$ of the respondents $(71.0 \%)$ completed the questions about cosmetic satisfaction. The proportion of patients undergoing mastectomy was $34.4 \%$. In the group of patients who underwent BCS, $21.6 \%$ stated that they desired surgical improvement, in comparison with $29.8 \%$ of the patients who underwent mastectomy. In the latter group, the desire for improvement remained constant up to 5 years after the initial operation, whereas it declined in the group of patients after BCS.

Conclusions: Patients should be offered breast reconstruction after mastectomy, even after a long-term follow-up period following the operation. The influence of the cosmetic results on partnership issues and sexuality should not be underestimated.

\section{PE556}

\section{Judgement bias in responding to questionnaires in patients suffering from cancer}

\section{Zenger M., Hinz A. ${ }^{1}$}

Universitätsklinikum Leipzig, Selbständige Abteilung für Medizinsche

Psychologie und Medizinische Soziologie, Leipzig

The aim of this study is to examine different aspects of psychosocial burdens of cancer patients by means of questionnaires. Furthermore we want to reflect the quality of life and the general health status of these patients as well as their individual needs and requirements for psychological assistance. The main focus is on changes over time. In this field of research the scientific literature takes more and more into account the phenomenon of the so called "response shift". It means, for example, that changes of self-evaluations of individual health related quality of life are not only due to objective real changes of the health status, but also to changes in a cognitive manner, namely, changes in internal standards, values or in the whole concepts about a construct like health and disease.

This study will quantify the phenomenon of "response shift", using the so called "Then-Test" among others. Further results will be expected from the relationship between the psychological situation of cancer patients on the one hand and the psychosocial care as requested or realized on the other hand. Thus, the results can contribute to develop specific care programs for persons suffering from cancer.

Patients with urological and gynaecological cancer tumours from five wards of the university hospital of Leipzig will be interviewed at three different times: during the stay in the hospital (T1), two weeks after discharge (T2) and three months later (T3).

This study aims at the evaluation of about 300 patients with complete data sets. Constituting parts of the questionnaire are among others the EORTC QLQC30, Life Satisfaction Questionnaire (FLZ), Hospital Anxiety and Depression Scale (HADS), Life Orientation Test (LOT) and Hornheider Screening (HS). First results will be expected in October 2008 conforming to the application. Representative surveys of the general German population will be used for a better comparability and integration of the results.

\section{PE557 \\ Results of the german ARIMIDEX ${ }^{\circledR}$ in the adjuvant therapy of not advanced breast cancer evaluation (AWB003) evaluating the safety, tolerability and acceptance of anastrozole (ARIMIDEX ${ }^{\circledR}$ ) in postmenopausal, hormone receptor positive women under daily practice conditions}

Hanusch C. ${ }^{1}$, Greven $K^{2}{ }^{2}$, Schumann J. ${ }^{3}$, Kuhn $T^{4}{ }^{4}$, Beldermann F. ${ }^{4}$, Warm $M^{5}$

${ }^{1}$ Schwesternschaft München vom Roten Kreuz, Frauenklinik, München; ${ }^{2}$ Praxis, Frauenheilkunde u. Geburtshilfe, Hannover; ${ }^{3}$ Praxis, Frauenheilkunde u. Geburtshilfe, Hamburg; ${ }^{4}$ Karl-Olga-Krankenhaus, Interdisziplinäres Brustzentrum, Stuttgart; ${ }^{5}$ Universitätsklinik Köln, Brustzentrum Köln/Frechen, Köln

Material and Methods: 1451 patients were enrolled in AWB003 (AWB: Anwendungsbeobachtung; In Practice Evaluation) between May 2005 and May 2007. Under daily routine conditions and without intervention regarding the selection of subjects, therapeutic decisions or diagnostic procedures, relevant data was collected over a period of 12 months at 3-monthly intervals focussing on safety, tolerability, predefined symptoms, overall quality of life and treatment acceptance of adjuvant anastrozole therapy in postmenopausal women with ER+ not advanced mamma carcinoma. Predefined symptoms were subjective breast cancer symptoms, hot flashes, musculoskeletal, gastrointestinal and gynaecological symptoms.

Results: Data of 1450 of patients was evaluable for this analysis (safety analysable population). Median age was 63 years, $20 \%$ of patients were 71 years and older, $64 \%$ of patients had one or more co-morbidities. $54 \%$ had received endocrine treatment prior to entering this evaluation (mostly tamoxifen), $45 \%$ were started on anastrozole upfront treatment at study start. Safety: 282 adverse events were reported. The most common adverse events were bone pain, arthralgia and hot flushes. 15 serious adverse events were 
reported including 5 drug related events as assessed by the investigators: 4 musculoskeletal events and one event of osteopenia. No other SAE was reported as being related to study drug. Cardiac events reported: 3 , of these one serious adverse event of heart failure. 137 adverse events were reported to be drug related. 51 adverse events and 2 serious adverse events led to discontinuation of anastrozole.

Tolerability, predefined symptoms: Tolerability and treatment acceptance were generally good. Subjective breast cancer symptoms decreased over time with $46.7 \%$ of patients being symptomatic at baseline, and $33.5 \%$ at 12 months, hot flashes decreased (50.7\% reported hot flashes at baseline, $42.7 \%$ at 12 months), musculoskeletal symptoms increased (from $46.8 \%$ to $50.7 \%$ at 12 months), gastrointestinal and gynaecological symptoms remained the same. Quality of Life: QoL improved over time both in the patients' and in the investigators' assessment. Investigators stated QoL to be "very good" for 18.2 $\%$ of patients at baseline and $35 \%$ at 12 months. $14.6 \%$ of patients judged their QoL to be "very good" at baseline, $28.7 \%$ at 12 months.

Conclusion: Anastrozole was generally safe and well tolerated in this postmenopausal, $\mathrm{HR}+$, adjuvant patient collective. No unexpected safety issues occurred. Overall quality of life improved and breast cancer related symptoms decreased over a period of 12 months.

\section{PE558}

\section{Sequential administration of docetaxel and sunitinib in women with advanced breast cancer: An exploratory evaluation}

Giorgetti C. ${ }^{1}$, Cardoso F. ${ }^{2}$, Isaksson-Friman $E^{3}$, Besse-Hammer $T^{2}{ }^{2}$, Verkh L. ${ }^{4}$, Rossi C. ${ }^{4}$, Bergh J. ${ }^{3}$

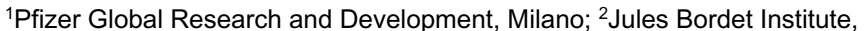
Medical Oncology \& Translational Research, Brussels; ${ }^{3}$ Karolinska Institutet and University Hospital, Stockholm; ${ }^{4}$ Pfizer Global Research and Development, La Jolla

Background: Sunitinib malate is an oral, multitargeted tyrosine kinase inhibitor of VEGFRs, PDGFRs, KIT, RET and FLT3. In mouse xenograft models of breast cancer (BC), sunitinib enhanced docetaxel antitumour activity. In a phase I study, maximum tolerated doses (MTDs) were sunitinib 37.5 $\mathrm{mg} /$ day on a $2 / 1$ schedule and docetaxel $75 \mathrm{mg} / \mathrm{m}^{2}$. This exploratory study assessed the pharmacokinetic (PK) profile, safety and preliminary efficacy of sunitinib and docetaxel for the first-line treatment of advanced BC.

Methods: Patients with unresectable locally recurrent or metastatic BC who relapsed after anthracycline-based chemotherapy in the adjuvant setting were enrolled (target: 20). The primary objective was to study the PK profile of sunitinib plus docetaxel. Secondary endpoints were safety and preliminary activity. Patients received intravenous (IV) docetaxel at $75 \mathrm{mg} / \mathrm{m}^{2}$ on Day 1 and oral sunitinib at $37.5 \mathrm{mg} /$ day for 2 weeks starting on Day 2 of a 3-week cycle. After docetaxel discontinuation, responsive patients (partial response $[\mathrm{PR}]$ or stable disease [SD]) could continue single-agent sunitinib until progressive disease $(\mathrm{PD})$.

Results: 13 patients were enrolled as of March 2007: 12 patients continue on therapy; 1 patient discontinued (no PD). 7/12 patients are receiving sunitinib after completing 6 cycles of sunitinib/docetaxel. Patients received a total of 66 cycles of sunitinib/docetaxel (median: 6 cycles/patient [range: 2-6]). The planned dose of sunitinib ( $37.5 \mathrm{mg} /$ day) was maintained in 11 patients. It was reduced to $25 \mathrm{mg} /$ day in 1 patient and increased to $50 \mathrm{mg} /$ day in 1 patient. Docetaxel was reduced to $60 \mathrm{mg} / \mathrm{m}^{2}$ in 4 patients due to febrile neutropenia and prolonged G4 neutropenia. The most commonly observed adverse event (AE) was severe neutropenia, which occurred at least once in all patients. Febrile neutropenia was reported in 3 patients. G-CSF has been administered in only a few cycles. Most AEs were of mild/moderate severity. Preliminary PK results showed that $\mathrm{C}_{\max }$ and $\mathrm{AUC}$ were similar on $\mathrm{C} 1$ and $\mathrm{C} 2$ for docetaxel and for sunitinib, ruling out the possibility of a drug?drug interaction. As of March 2007, 8 patients showed a PR and 4 had SD as best response (RECIST). Conclusions: Oral sunitinib $37.5 \mathrm{mg} / \mathrm{day}$ on a $2 / 1$ schedule with docetaxel 75 $\mathrm{mg} / \mathrm{m}^{2} \mathrm{IV} \mathrm{q} 3 \mathrm{w}$ has a manageable safety profile when given as a first-line treatment in patients with advanced BC. Preliminary PK data show no drug?drug interactions, and preliminary efficacy results are encouraging.

\section{PE559}

Questionnaire of HOPE - Hoffnungsbogen first web-based follow-up questionnaire that is filled in by the patients themselves

\author{
Raab G. ${ }^{1}$, van den Bergh M. ${ }^{2}$ \\ ${ }^{1}$ Frauenarztpraxis, München; ${ }^{2}$ Asthenis $\mathrm{GmbH}$, Aschheim/München
}

Today management of breast cancer is increasingly focused on breast cancer centres, some of them being even certificated. Therefore newest scientific results can be quickly translated into modern treatment strategies. But unfortunately the key question is hardly addressed by breast cancer centres: Do their efforts improve patients' outcome?

The reason for that is the lack of follow-up data. Although patients' complete data of diagnostic and treatment is electronically collected and analysed by the centres, it is a big problem to document follow-up data. As follow-up is not in the hands of the centres but in the hands of the practitioners, who have a completely different focus of interest, this specific and important data is almost impossible to receive.

Therefore we launched the project "Hoffnungsbogen", Questionnaire of Hope. This is the first web-based follow-up questionnaire for patients. According to the EUSOMA follow-up data set, this questionnaire has been customized to be used by patients. In addition, patients can view their complete electronic breast cancer charts and show them to who ever, when ever and where ever they want to. Questionnaire of Hope has been integrated into the professional internet portal www.asthenis.com/portal .

The aim of this project is to encourage the patients to actively provide their own follow-up data for the data bases of the breast cancer centres. The combination with the view of their charts transfers the patients into an active role in the management of their disease.

Questionnaire of hope can be used without any costs by all patients, who are treated in breast cancer centres that use the documentation software ODSeasy ${ }^{\circledR}$ and the web-based module ODS ${ }^{\circledR}$ follow-up. Only the connection with a widely used software can address the majority of breast cancer patients. As the data of about 35.000 patients in Germany per year with newly diagnosed breast cancer is collected by ODSeasy ${ }^{\circledR}$, this software is appropriate.

A lot of special features such as reminder e-mails from the centres, e-mail contact with the centres and the practitioners, chat-room and information platform represent a modern and life-style adapted tool for interaction. This will improve patients' compliance, make them think more active and therefore more positive and will last but not least deliver follow-up data, that otherwise would be lost.

Perhaps Questionnaire of Hope can by itself improve outcome of the participating patients.

Questionnaire of Hope is a project initiated by asthenis $\mathrm{GmbH}$.

\section{PE560}

\section{Primary squamous cell cancer of female breast}

\section{Vescia M. ${ }^{1}$, Herbert $T .^{2}$, Vogl $T .^{3}$, Möbus $V .{ }^{1}$}

${ }^{1}$ Städt. Kliniken Frankfurt Höchst, Frauenklinik, Frankfurt Höchst; ${ }^{2}$ Städt. Kliniken Frankfurt Höchst, Pathologie, Frankfurt Höchst; ${ }^{3} \mathrm{~J}$. W. Goethe Universität, Radiologie, Frankfurt a.M.

Squamous Cell Cancer (SCC) of the breast is an uncommon tumour, concerning less than $0.1 \%$ of all breast carcinomas. Diagnosis is confirmed when more than $90 \%$ of the malignant cells are of the squamous type. SCC is thought to arise directly from the epithelium of the mammary ducts. In a review of literature, the first case was reported in 1908 and there are 92 cases documenting the management and clinical outcome of breast SCC.

We report on a 56-year-old female patient who presented with an $11 \mathrm{~cm}$ palpable tumour in the left breast. The sonography and mammography showed a round, intracystic lesion with a diameter of $11 \mathrm{~cm}$. Liver ultrasound and CTscan proved hepatic metastases. Final histopathologic assessment of breastpreserving resection confirmed the diagnosis of keratinizing intracystic squamous cell carcinoma (pT3 pNx M1 G3). Due to the visceral metastases no axillary node dissection was done. The search for primary source of the squamous cell carcinoma did not reveal any extramammary cancer. On the base of hepatic metastases and the SCC, no systemic chemotherapy was applied. The patient received an intraarterial chemoembolisation and laser 
induced thermotherapy. In 2005 a local relapse occurred. Axillary dissection showed 3 lymphnodes metastases. Until today no further relapse occurred. In conclusion breast SCC is an aggressive disease and prognosis and therapy is still a subject of controversy. Systemic therapies have to be individual and can lead to long lasting disease free survival even in patient with primary metastatic disease.

\section{PE561 \\ Adjuvant endocrine therapy of patients with breast cancer registered in the cancer center Regensburg}

Görse R. ${ }^{1}$, Kayser K. ${ }^{1}$, Stefanie K. ${ }^{1}$, Zeller V. ${ }^{1}$, Klinkhammer-Schalke $M^{2}{ }^{2}$, Hofstädter $F^{3}$, Ortmann $O^{1}{ }^{1}$

${ }^{1}$ Universitätsfrauenklinik, 93053 Regensburg; ${ }^{2}$ Tumorzentrum Regensburg, Regensburg; ${ }^{3}$ nstitut für Pathologie, Regensburg

Background: The majority of patients with primary breast cancer has endocrine responsive disease. Adjuvant endocrine therapy with tamoxifen for 5 years improves disease free and overall survival. In recent years large randomized trials have demonstrated that aromatase inhibitors used in upfront, sequential or switch regimens are surperior to tamoxifen treatment of postmenopausal women. This led to modifications of treatment guidelines. Here we investigated whether adjuvant endocrine treatment has changed between 1998 - 2005 by analyzing data from the Cancer Center Regensburg.

Methods: The Cancer Center Regensburg collects data from 50 hospitals situated in the regions Oberpfalz and Niederbayern, the University Hospital of Regensburg and 1100 physicans in practice. The region Oberpfalz and Niederbayern consists of 2,3 million inhabitants. We analysed data from 5370 patients with primary breast cancer diagnosed from 1998 to 2005. The reports of 5370 patients in total and of 4055 patients with hormone responsive breast cancer were analysed.

Results: 1171 of all reported patients with breast cancer in the period of 1998 2005 were pre-and 4199 postmenopausal. 70,6 \%, 76,9\% had endocrine responsive disease respectively. Both pre- and postmenopausal patients received in $82 \%$ endocrine therapy. $57 \%$ of the premenopausal patients and $66 \%$ of the postmenopausal patients were treated with tamoxifen. The total rate of aromatase inhibitor treatment was $12,7 \%$ in premenopausal and 21,1 $\%$ in postmenopausal cases. During the last three years of the investigation period (2003 - 2005) we observed an increasing number of patients receiving therapy with aromatase inhibitors.

Conclusions: Most of the women with primary breast cancer included in this study were treated with tamoxifen. Increasing numbers of patients received aromatase inhibitors. However, the proportion is still low indicating that improvement of guideline implementation is important.

\section{PE562}

\section{Quality of life: Learning to cope with the changes in body image and treatment effects of breast cancer therapy - The role of rehabilitation}

\section{Gallhofer G. ${ }^{1}$, Netter P. ${ }^{2}$, Brückner U. ${ }^{3}$, Wendt $T .{ }^{1}$ \\ ${ }^{1}$ Reha-Zentrum Bad Nauheim Taunus-Klinik, Taunus-Klinik, Bad Nauheim; ${ }^{2}$ Universität, Psychologie, Giessen; ${ }^{3}$ DRV-Bund, Berlin}

Various treatment modalities for breast cancer, (surgery, chemotherapy, radiotherapy and antihormone therapy) may lead to major alterations in body image, sleep disturbances, impairment of mood, activity and vigilance.

For the complex task to restitute traumatised patients, rehabilitation with a multidisciplinary team consisting of physicians, physiotherapists, lymphtherapists, psychologists, dieticians as well as ergotherapists and social workers can offer comprehensive help.

The aim of the present study was to investigate how body image (i.e ratings on acceptance of cosmetic results) had changed during their rehabilitation period according to the type of surgical, radiological and hormone therapy they had experienced. Also changes of subjective feelings and motivation for rehabilitation and their influence on change of body image were targets of the study. We tested 200 consecutive patients who underwent rehabilitation in an inpatient setting. Their status was investigated with the following inventories: Acceptance of body image questionnaire (checking satisfaction with the results of surgery), Paremo version 2.1 (motivation for the rehabilitation process, readiness to change, ability to seek help and social support, impairment of every day life activities, hopelessness, initiative and knowledge) and BSKE - assessing current wellbeing by 6 categories of adjectives (positive affect, fear, hostility, inactivity, vigilance and tendency of introversion). These inventories were applied at the beginning and the end of the rehabilitation period

Results demonstrate significant improvement regarding the acceptance of body image as well as reduction of fear of recurrence. Furthermore, there was an increase of vigilance and activity and a decrease of hostility

Women with low scores on perceived suffering and low scores on hopelessness improved most with respect to ratings on body image. While chemotherapy and radiation did not seem to affect these ratings, women seemed to improve their satisfaction with body image after therapy with aromatase inhibitors as opposed to those treated with tamoxifen. The two hormone treatments also differed with respect to change scores of hostility as compared to those without hormonal treatment. Results demonstrate that rehabilitation can change a number of psychological disturbances after breast cancer therapy and that the outcome partly depends on several dispositional factors and type of primary treatment

\section{PE563}

\section{Genetic polymorphisms as predictors of therapy response in a trial of neoadjuvant systemic therapy for primary invasive breast cancer}

\section{Marmé F. ${ }^{1}$, Hahn M. ${ }^{2}$, Lichter $P^{2}{ }^{2}$, Rom J. ${ }^{1}$, Mansouri K. ${ }^{3}$,} Bauknecht T. ${ }^{3}$, Sinn H.-P. ${ }^{4}$, Sohn C. ${ }^{1}$, Schneeweiss A. ${ }^{1}$

${ }^{1}$ Universitätsfrauenklinik, Abt. Allg. Gynäkologie und Geburtshilfe, Heidelberg; ' 2 Deutsches Krebsforschungszentrum, DKFZ, Heidelberg; ${ }^{3}$ Lilly Deutschland GmbH, Bad Homburg; ${ }^{4}$ Universität, Pathologisches Institut, Heidelberg

Background: Single nucleotide polymorphisms (SNPs), Insertions/Deletions (InDels) and variations in the number of tandem repeats (VNTRs) have been implicated in the prediction of therapy response and toxicity in many trials of adjuvant and palliative chemotherapy in a wide range of solid tumours and hematologic malignancies.

Neoadjuvant systemic therapy (NST) with its assessment of pathologic complete response (pCR), so far the best surrogate parameter for cure of primary breast cancer, provides a unique opportunity to rapidly identify such genetic predictors.

Patients and Methods: Currently, an international, randomized phase II study of 2 sequential regimens as NST is being conducted in patients with primary invasive breast cancer T2-4a-c N0-2 M0. Patients receive 4 cycles of doxorubicin/pemetrexed, followed by 4 cycles of docetaxel (AP-Doc) or 4 cycles of doxorubicin/cyclophosphamide, followed by 4 cycles of docetaxel (AC-Doc). Tumor tissue, blood, and serum are collected at baseline and, if available, after 4 cycles of chemotherapy, and at surgery. The clinical objectives are to assess $\mathrm{pCR}$ rate, tumor response, rate of histologically negative axillary lymph nodes, disease-free survival and safety after NST with AP-Doc or AC-Doc. Translational research objectives include the identification of SNPs, InDels and VNTRs that predict and therapy response specific for pemetrexed, a multi-target folate inhibitor. We therefor analyzed 8 polymorphisms in the 3 target genes of pemetrexed [thymidylate synthase (TS), dihydrofolate reductase (DHFR) and glycinamide ribonucleotide formyltransferase (GARFT)] and the two genes involved in intracellular import [reduced folate carrier 1 (RFC1)] and intracellular activation of pemetrexed [folylpolyglutamate Synthase].

Results: As of November 2007 all of the 256 patients planned for this study had been enrolled at 12 European centers and we have analysed genomic DNA isolated from whole blood samples of 232 of these patients in respect to the polymorphisms in the relevant genes.

Conclusion: We anticipate this study will provide a better understanding of the treatment options with pemetrexed in primary breast cancer and give insight into genetic polymorphisms as new marker sets in prediction of response. As a future objective these genetic markers might also prove valuable in prediciting toxic responses to therapy that might be responsible for treatment failure. 


\section{Breast Cancer \\ Poster Presentation}

PO301

Analysis of single nucleotide polymorphisms in the promoter region of ICB-1 gene in women with breast cancer

\section{Konwisorz A. ${ }^{1}$, Springwald A. ${ }^{1}$, Juhasz-Böss $I .{ }^{1}$, Ortmann $0 .{ }^{1}$} Treeck O. ${ }^{1}$

${ }^{1}$ Universität Regensburg, Klinik für Frauenheilkunde und Geburtshilfe, Regensburg

Icb-1 (C1orf38) is a human gene initially described by our group to be involved in in vitro differentiation processes of tumor cells derived from gynecological malignancies. Icb-1 transcript levels associated with differentiation status also were shown to be upregulated by $17-\beta$ estradiol in breast cancer cells. In this study we tested the hypothesis that polymorphisms in the promoter region of icb-1 gene may be associated with increased risk for breast cancer. We investigated two icb-1 promoter region polymorphisms, rs1467465 and rs12048235, for association to breast cancer risk. A total of 156 breast cancer cases and 148 controls were included in the study. DNA isolated from blood samples of these patients was analyzed by means of an allele specific tetra-primer PCR approach. Breast cancer patients more frequently carried the homozygous genotype AA of SNP rs1467465 (17.31\%) than healthy women $(10.81 \%)$ suggesting that this genotype confers an increased breast cancer risk (OR 2.079, $\mathrm{p}=0.041$ ). Allele G of SNP rs 1467465 was significantly less frequent in breast cancer patients than in controls and thus is suggested to have a weak protective effect on breast cancer development (OR 1.452, $\mathrm{p}=0.027)$. In contrast, no significant association to breast cancer risk was found for SNP rs12048235. In conclusion, our data suggest that single nucleotide polymorphism rs1467465 in the promotor region of icb- 1 gene is able to affect breast cancer risk. Whether this association is due to altered expression levels of icb- 1 gene resulting from this polymorphism has to be examined in further studies.

\section{$\mathrm{PO} 302$}

\section{Selective endothelin-A-receptor antagonist ZD4054 reduces breast cancer cell migration and invasion and exhibits} additive effects with aromatase inhibitors and fulvestrant

\section{Smollich M. ${ }^{1}$, Götte M. ${ }^{1}$, Fischgräbe $J .{ }^{1}$, Radke I. ${ }^{1}$, Chen S. ${ }^{2}$, Kiesel L. ${ }^{1}$, Wülfing $P{ }^{1}$}

${ }^{1}$ Universitätsklinikum Münster, Universitätsfrauenklinik, Münster; ${ }^{2}$ Beckman Research Institute, Duarte, CA, USA

Background: In breast cancer, the endothelin axis (ET axis) with endothelin1 (ET-1), endothelin-A-receptor $\left(\mathrm{ET}_{\mathrm{A}} \mathrm{R}\right)$, and endothelin-converting enzyme-1 (ECE-1) is of major importance for tumour progression and individual prognosis. Overexpression of ET-1, $\mathrm{ET}_{\mathrm{A}} \mathrm{R}$, and ECE-1 is associated with aggressive disease, metastasis and decreased survival. By binding to $\mathrm{ET}_{\mathrm{A}} \mathrm{R}, \mathrm{ET}-1$ induces cell proliferation, angiogenesis and anti-apoptosis. Therefore, selective $\mathrm{ET}_{\mathrm{A}} \mathrm{R}$ antagonism, alone or in combination with endocrine therapies, represents an innovatively targeted therapy for breast cancer.

Methods: We characterised the effects of the selective $\mathrm{ET}_{\mathrm{A}} \mathrm{R}$ antagonist ZD4054 on breast cancer cell gene expression, proliferation, migration, and invasion. Changes in gene expression were quantified by real-time PCR. Proliferation was analysed using bromodeoxyuridine and alamarBlue ${ }^{\circledR}$ assays. Migration and invasion assays were performed using modified Boyden chambers, which were coated with a Matrige $l^{\circledR}$ membrane for the latter assays, to simulate the physiological basement membrane barrier.

Results: Investigating the effect on the ET axis expression, we found that ZD4054 significantly reduced ET-1, $\mathrm{ET}_{\mathrm{A}} \mathrm{R}$, and ECE-1 mRNA expression in different breast cancer cell lines (MCF-7, MDA-MB-231, MDA-MB-468) in a concentration-dependent manner. As expected from previous studies, proliferation of breast cancer cells was not affected by ZD4054. However, ZD4054 significantly reduced cellular migration by up to $26.7 \%$ (MDA-MB-468; $P<0.001$ ) and cellular invasion by up to $46.3 \%$ (MCF-7; $P<0.001$ ). In aromatase-overexpressing MCF-7aro cells, when either ZD4054 or aromatase inhibitors (anastrozole, letrozole) were administered alone, there were only minimal effects on cellular migration. However, combinations of ZD4054 with either anastrozole or letrozole significantly reduced cellular migration $(P<0.05)$. In MCF-7 cells, combination of ZD4054 with the estrogen receptor downregulator fulvestrant produced reduction of cellular migration and invasion by $36.0 \%(P=0.027)$ and $56.7 \%(P<0.001)$, respectively, with effects significantly exceeding those seen with either compound alone.

Conclusions: Our data are the first to indicate that selective antagonism of $\mathrm{ET}_{\mathrm{A}} \mathrm{R}$ by ZD4054 may represent a promising approach in future breast cancer therapy. Additive anti-invasive effects of ZD4054, when co-administered with aromatase inhibitors or fulvestrant, support a rationale for the clinical use of ZD4054 in combination with endocrine therapies.

\section{PO303}

AKAP12 / gravin - A candidate tumor suppressor gene in breast cancer is inactivated by epigenetic mechanism

\section{Blankenburg M. ${ }^{1}$, Hofmann $W^{2}$. Scherneck $S^{1}$}

${ }^{1}$ Max Delbrück Center for Molecular Medicine, Department of Tumor Genetics, Berlin; ${ }^{2}$ Berufsverband Deutscher Humangenetiker e.V., Berlin

AKAP12 (A-kinase anchoring protein) is a candidate tumor suppressor gene in breast cancer. This gene, also known as gravin, has been mapped on chromosome 6q24-25.2, a hot spot region of loss of heterozygosity ( $\mathrm{LOH}$ ) in breast cancer. AKAP12 acts as a scaffold protein that binds protein kinase A (PKA), protein kinase $\mathrm{C}$ (PKC) and protein phosphatases, associating reversibly with the b2adrenergic receptor.

Significant down regulation of $A K A P 12$ expression in breast tumors was shown by cancer profiling and chip array experiments, northern blot analysis and semi-quantitative RT-PCR. In addition, the AKAP12 expression was investigated by Western Blot experiments and tissue microarray.

To correlate expression of AKAP12 mRNA and LOH at the AKAP12 locus in primary breast tumors we analysed tumor samples in comparison to matched normal genomic DNA by sequencing of different SNPs and by amplification of the internal gene marker D6S476.

To evaluate whether down regulation of $A K A P 12$ expression is due to aberrant methylation we performed 5'-Aza-dC treatment, methylation-specific PCR and bisulfite sequencing.

Based on the expression data we investigated the effect of AKAP12 on breast cancer cell growth by transient and stable transfection of breast cancer cell lines. The tumor suppressor activity was examined in nude mice. Our data showing lowered AKAP12 expression in several breast tumor cell lines and tumor samples as well as its ability to retard cell growth support an important role of AKAP12/gravin in the development of breast cancer.

\section{$\mathrm{PO} 304$}

\section{Ki-67 as a prognostic molecular marker in breast cancer}

Lux M.P. ${ }^{1}$, Bani M.R. ${ }^{1}$, Schrauder M.G. ${ }^{1}$, Löhberg C. ${ }^{1}$, Beckmann K. ${ }^{1}$, Wiesner F.G. ${ }^{2}$, Beckmann M.W. ${ }^{1}$, Fasching P.A. ${ }^{1}$ ${ }^{1}$ Universitätsklinikum Erlangen, Universitäts-Brustzentrum Franken (UBF), Erlangen; ${ }^{2}$ Gynäkologische Praxis, Erlangen

Introduction: Prognostic and predictive factors need to be identified in order to establish the indication for adjuvant treatment on an individual basis in patients with breast carcinoma (BC), and to allow adequate weighing up of the benefits and risks involved. Tumor size, estrogen receptor (ER)/progesterone receptor (PR) status, nodal status, tumor grade, and lymphatic and vascular invasion are recognized parameters. A change in the therapeutic approach is taking place, with increasing indications for preoperative chemotherapy. The criteria for the indication are difficult to establish, as only clinical parameters and punch biopsy findings with biological parameters are available. Specific prognostic parameters need to be evaluated. Ki-67 expression is an interesting candidate, as it allows assessment on the basis of a relatively small number of cells from a punch biopsy. However, there is a lack of relevant studies on this topic with sufficiently long follow-up periods.

Materials and Methods: In a large group of patients $(n=1564)$ at the University Breast Center Franconia (UBF), the present study correlated the Ki-67 proliferation rate with the traditional prognostic parameters. The prognostic efficacy of Ki-67 for assessing the disease-free survival (DFS) and overall survival (OS) was investigated on the basis of a long follow-up period. 